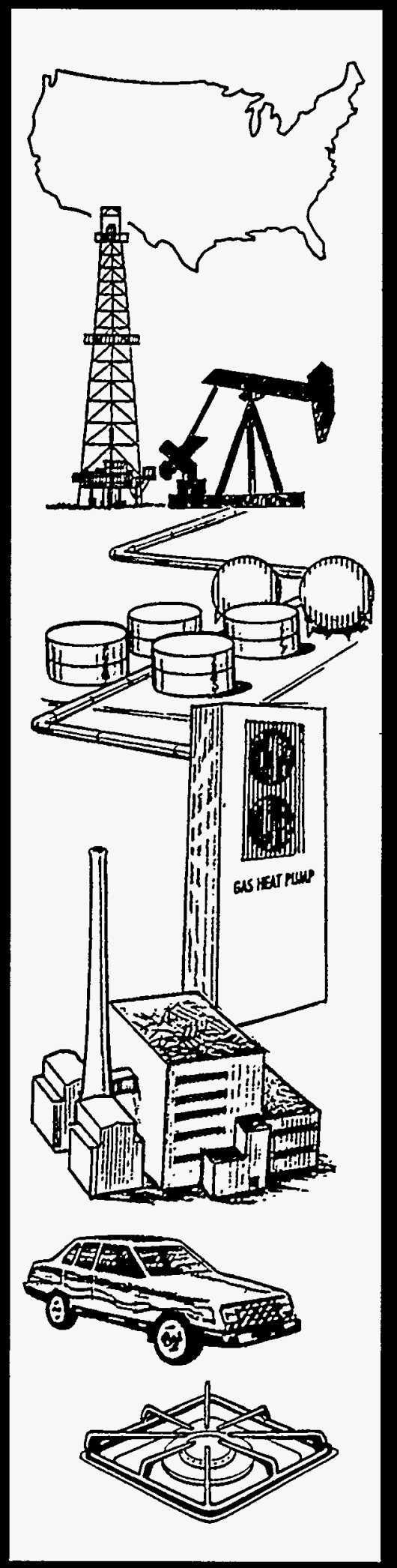

\title{
natural gas strategio plan and program crosscut plans
}

\section{U.S. Department of Energy}


This report has been reproduced directly from the best available copy.

Available to DOE and DOE contractors from the Office of Scientific and Technical Information, P.O. Box 62, Oak Ridge, TN 37831; prices available from (615) 576-8401.

Available to the public from the U.S. Department of Commerce, Technology Administration, National Technical Information Service, Springfield, VA 22161. (703) 487-4650.

Printed on recycled paper with soy ink.

$\because \cdot 2+\cdots$

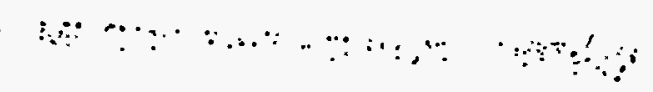




\section{natural gas strategic plan \\ and program crosscut plans}

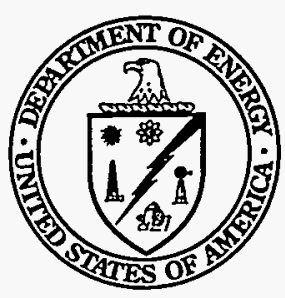

Office of Policy

Office of Fossil Energy

Office of Energy Research

Office of Energy Efficiency and Renewable Energy

Energy Information Administration

\section{U.S. Department of Energy}

Washington, DC 20585

June 1995 


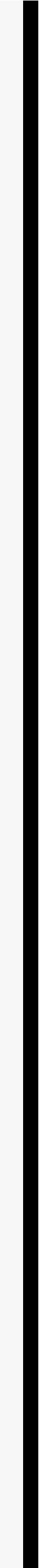


Page No.

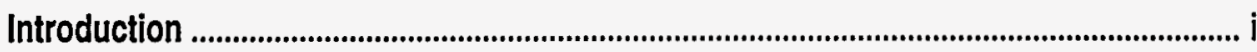

Natural Gas Strategic Plan ...................................................................................... 1-1

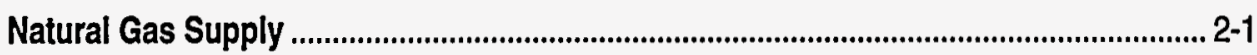

Delivery and Storage ........................................................................................... $3-1$

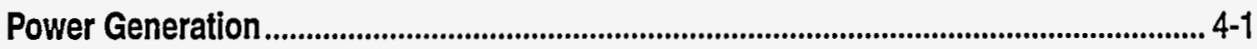

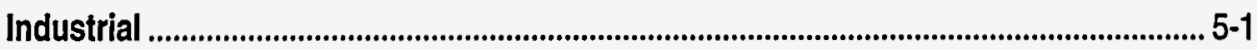

Residential and Commercial .................................................................................. 6-1

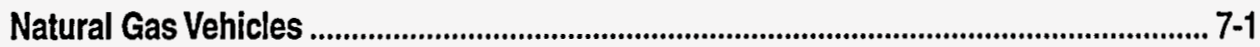

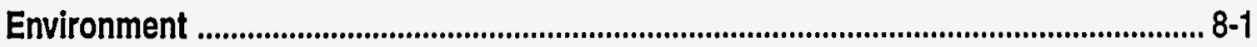

Crosscutting Issues ...................................................................................................... 9-1 


\section{introduction}

This document comprises the Department of Energy (DOE or the Department) Natural Gas Strategic Plan, individual program-level strategic plans, and a discussion of crosscutting issues.

DOE's natural gas programs are aimed at simultaneously meeting our national energy needs, reducing oil imports, protecting our environment, and improving our economy. The Natural Gas Strategic Plan represents a Department-wide effort on expanded development and utilization of natural gas, and defines the roles of the Federal government and U.S. industry in partnering to accomplish the strategic goals defined. The four overarching goals of the Natural Gas Strategic Plan are to: (1) foster the development of advanced natural gas technologies; (2) encourage the adoption of advanced natural gas technologies in new and existing markets; (3) support the removal of policy impediments to natural gas use in new and existing markets; and (4) foster technologies and policies to maximize the environmental benefits of natural gas use. The strategic issues, program goals, and related strategies of the Strategic Plan are intended to overcome the technology, market, policy/regulatory, and environmental barriers to increased use of natural gas in the Nation's energy future. The program goals are presented below.

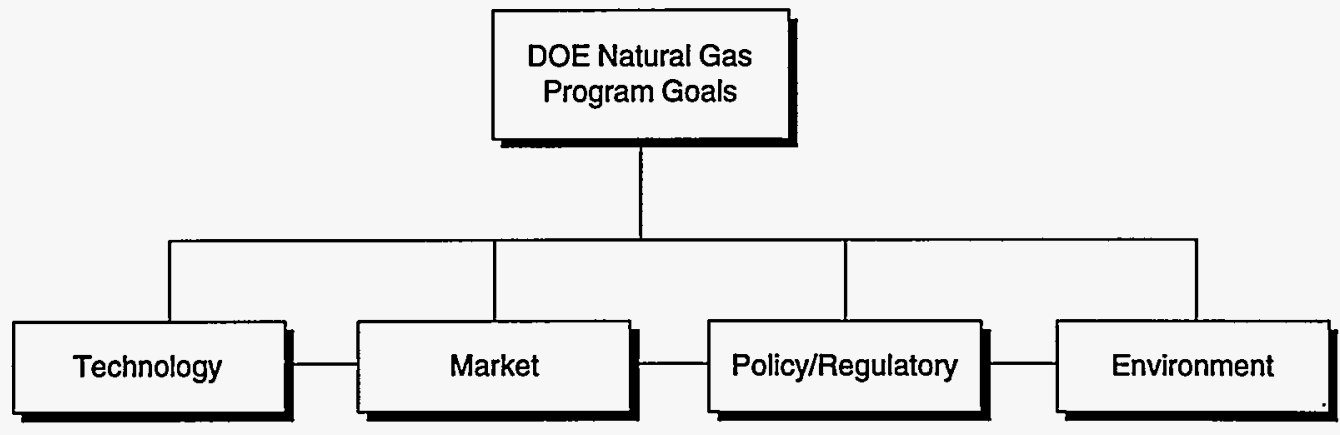

Foster the development of advanced natural gas technologies to explore, produce, store, transport, and use natural gas cleanly, more efficiently, and more extensively in the electricity generation, industrial, transportation, and residential and commercial sectors.
Encourage increased use of natural gas in new and existing markets in the supply, electricity generation, industrial, transportation, and residential and commercial sectors.
Identify, analyze, and support the removal of regulatory and policy impediments to efficient production, transportation, and use of natural gas in the electricity generation, industrial, transportation, and residential and commercial sectors.
Foster advanced technologies and policies that minimize the impact of exploration and production operations and maximize the environmental benefits of natural gas use in the electricity generation, industrial, transportation, and residential and commercial sectors. 
The Natural Gas Strategic Plan recognizes the challenges and opportunities facing increased U.S. natural gas use. These challenges and opportunities include maximizing the utilization of our domestic resource base; developing new ways in which to maximize the economic, environmental, and national security benefits offered by natural gas; and establishing policies and regulations to allow natural gas to compete with other fuels in new and existing markets.

DOE's natural gas research, development, and demonstration (RD\&D) program activities crosscut the Offices of Fossil Energy, Energy Efficiency and Renewable Energy, Energy Research, and Policy, and the Energy Information Administration (EIA). Specific activities are carried out and funded either independently by each Office or jointly, depending on the Office mission, program focus, crosscutting programmatic relationships, and budgetary considerations. The overall program strategy has been developed by a Department-wide planning Committee that has been charged with ensuring that all natural gas programs are conducted with a single strategic focus to provide a united and integrated program to the natural gas industry and stakeholders. The Committee is an integral part of the Departmental Natural Gas Strategic Planning organization as shown in Exhibit 1. The Committee comprises representatives from the offices with responsibility for natural gas programs and policies. In order to better coordinate and integrate government and private sector gas program activities, officials from the American Gas Association and the Gas Research Institute also serve as observers on the Committee.

The structure of the Committee parallels that of the Gas Research Institute in that it adopts the same technology panels. The Committee also includes a Market Entry Panel that guides the technology panels in identifying industry and end-use technology needs, developing industrydriven $R D \& D$ programs, and program outreach and technology transfer.

In the development of the Natural Gas Strategic Plan, the Committee established seven technology panels in the following focus areas: Natural Gas Supply, Delivery and Storage, Power Generation, Industrial, Residential and Commercial, Natural Gas Vehicles, and Environment. Each panel, comprising members from program offices and representative industry observers, developed a program strategic plan that reflects the strategic direction and goals provided in the Department-wide Natural Gas Strategic Plan. The structure of the fiscal year (FY) 1995 natural gas program, comparison to the FY 1994 program, and technology panel goals are provided in Exhibit 2. 


\section{Exhibit 1 - DOE Natural Gas Strategic Planning Organization}

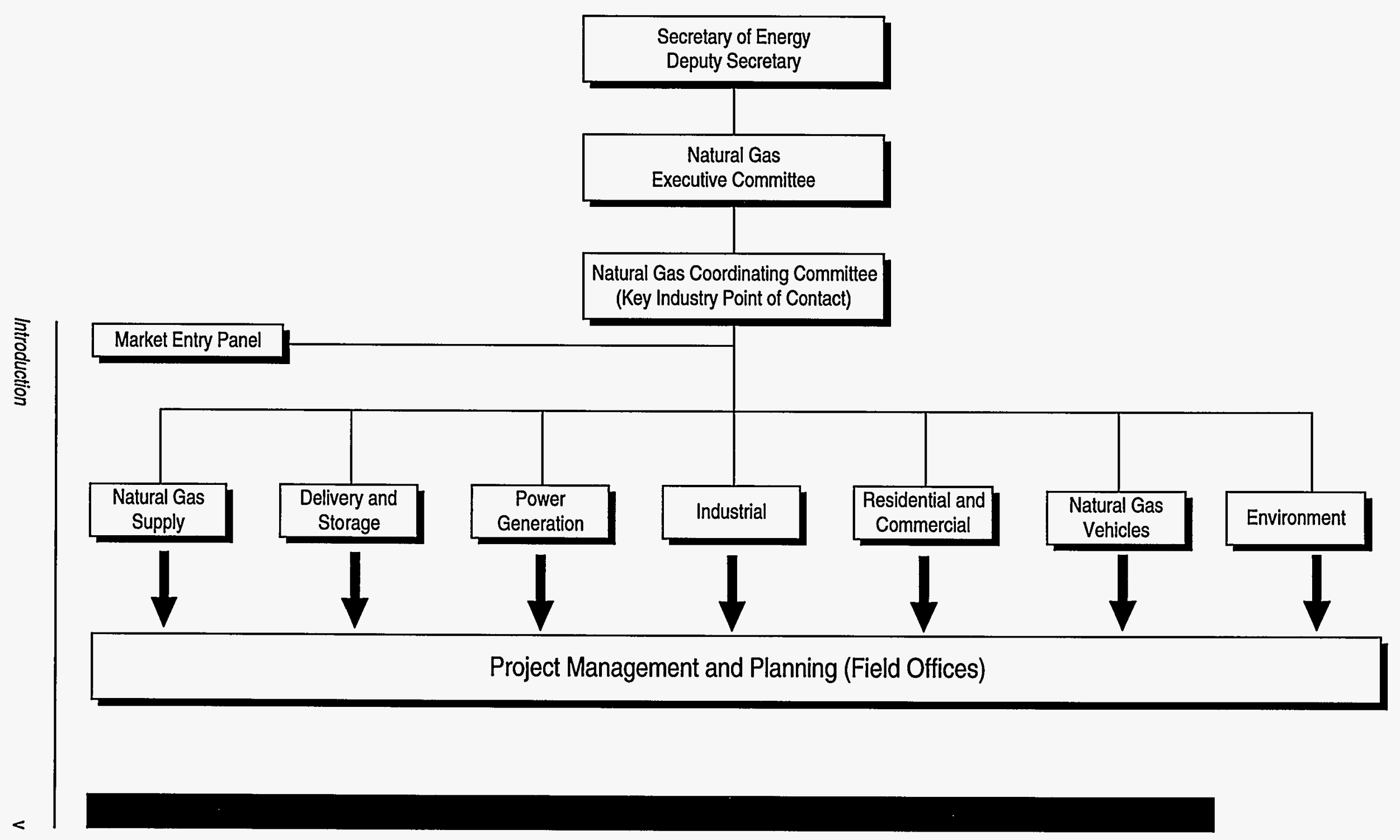




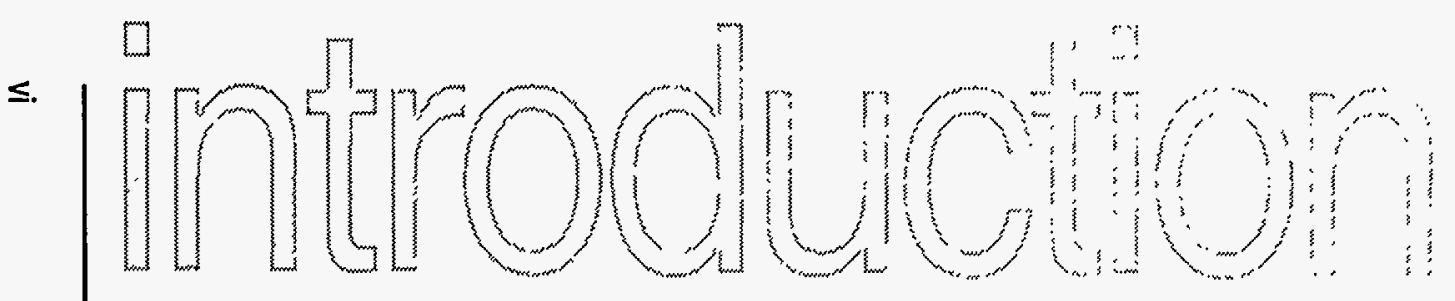

\section{Exhibit 2 - Natural Gas Program Structure and Goals}

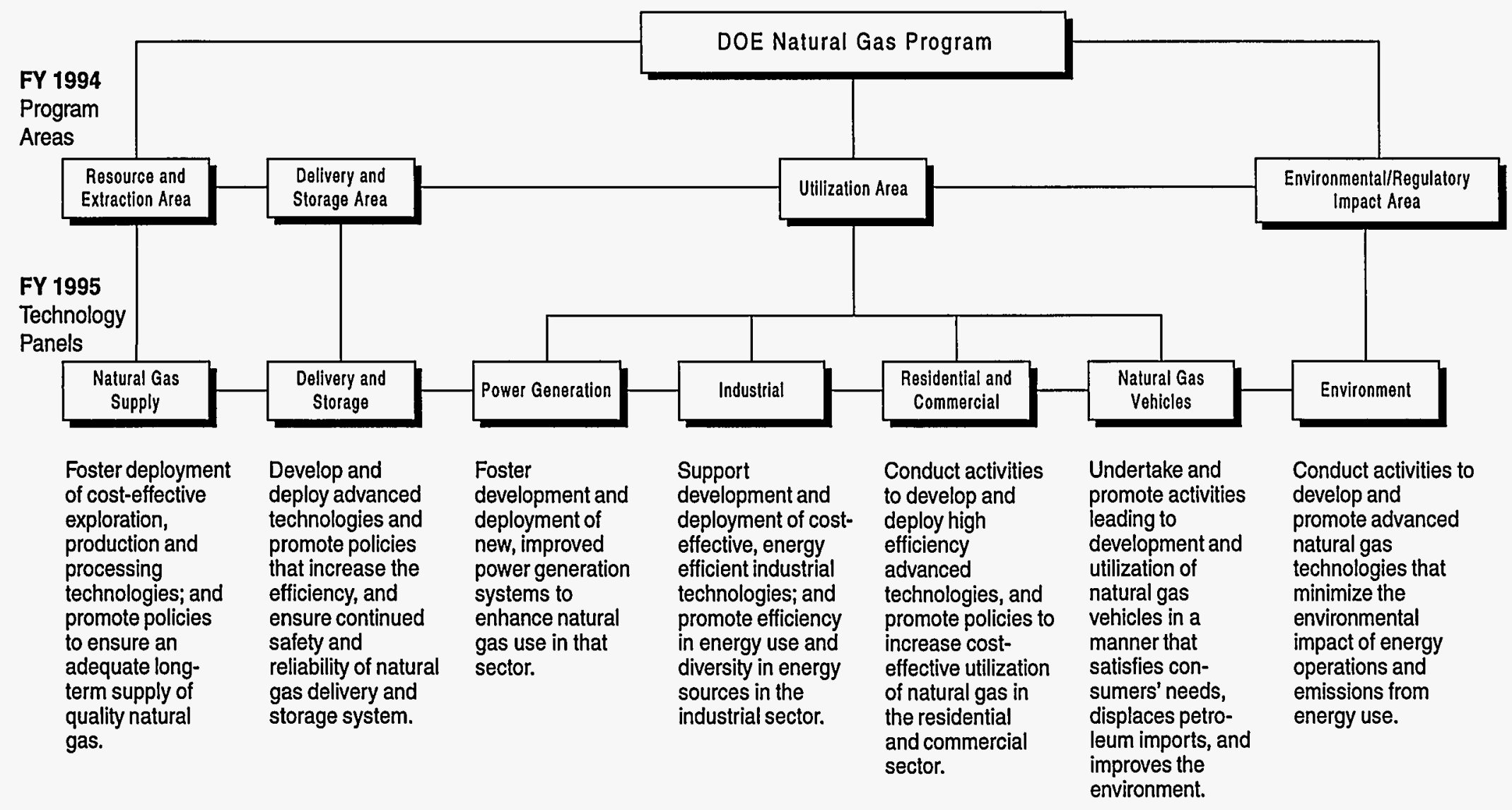




\section{historical trends}

Consumption: Natural gas is becoming an increasingly important part of the Nation's energy resources portfolio, as indicated in its recent historical use patterns. Throughout the 1950 s and 1960s, the market for natural gas expanded as low prices encouraged demand. Of the many factors affecting natural gas markets during those decades, Federal and State regulatory commissions were the most influential. Below-market rates for certain categories of natural gas, coupled with strong demand, ultimately resulted in regional shortages during the second half of the 1970s.

In 1972, total consumption of natural gas reached an all-time high of 22 trillion cubic feet (Tcf). Thereafter, uncertainties about supply and rising energy prices began to erode demand. By the 1980 s, lower demand resulted in a short-term surplus of deliverable natural gas and gas well shut-ins in many producing areas. In 1986, natural gas consumption totaled $16 \mathrm{Tcf}$, the lowest annual total since 1965. During the 1980s, regulatory and legislative changes allowed consumers to purchase natural gas directly from producers and to arrange for pipeline and distribution companies to deliver it to them for a fee. Federal Energy Regulatory Commission (FERC) Order No. 636 extended that trend toward a more efficient market by requiring interstate pipeline companies to unbundle (separate) their sales and transportation services.

After the 1986 low point, natural gas consumption trended upward, reaching about $21 \mathrm{Tcf}$ in 1994. Electric utilities and the commercial sector consumed more natural gas in 1994 than they had in 1993. Electric utility consumption of natural gas rose to 3.0 Tcf, a 12-percent increase, and commercial sector consumption also totaled $3.0 \mathrm{Tcf}$, up 4.9 percent. Consumption in the industrial sector (the largest consuming sector) fell slightly (0.2 percent) to 9.2 Tcf in 1994 . Residential consumption fell 2.6 percent to $4.8 \mathrm{Tcf}$ and transportation consumption remained at the 1993 level of $0.6 \mathrm{Tct}$.

According to the Energy Information Administration, natural gas consumption will continue to grow in all end-use sectors. These projections, as compared to 1993 levels, are shown in Exhibit 3.

Production: In 1994, gross withdrawals of natural gas from wells totaled 24 Tcf, up for the eighth consecutive year. Most withdrawals came from onshore wells and State offshore wells, but 5.2 Tcf were Federal offshore withdrawals. The U.S. total of natural gas gross well withdrawals includes a small but rapidly growing amount of methane produced from coalbeds. In 1993, gross withdrawals of coalbed methane totaled about 732 billion cubic feet (Bcf), an amount equal to over 4 percent of U.S. total dry production. 
Exhibit 3 - Natural Gas Consumption: 1993, 2000, and 2010 (Tcf/Year)

\begin{tabular}{|l|c|c|c|}
\hline Market Sector & 1993 & 2000 & 2010 \\
\hline Residential & $4.96(24.5 \%)$ & $5.01(22.7 \%)$ & $4.89(19.9 \%)$ \\
\hline Commercial & $2.89(14.3 \%)$ & $2.95(13.3 \%)$ & $2.97(12.1 \%)$ \\
\hline Industrial & $7.61(37.6 \%)$ & $8.68(39.2 \%)$ & $9.50(38.6 \%)$ \\
\hline Electric Generators & $2.94(14.5 \%)$ & $3.34(15.1 \%)$ & $4.72(19.2 \%)$ \\
\hline Transportation & $0.01(<0.1 \%)$ & $0.15(0.7 \%)$ & $0.42(1.7 \%)$ \\
\hline Other & $1.81(9.0 \%)$ & $1.98(9.0 \%)$ & $2.09(8.5 \%)$ \\
\hline Total & 20.22 & 22.11 & 24.59 \\
\hline
\end{tabular}

Source: Annual Energy Outlook, Energy Information Administration, January 1995, Reference Case.

Imports: Natural gas imports also have been increasing since 1986. Historically, Canada has been the major supplier of U.S. natural gas imports, with Algeria and Mexico supplying smaller amounts. The growth in U.S. imports of natural gas from the 1986 level of 750 billion cubic feet (a 17-year low at the time) to 2.5 Tcf in 1994 was due almost entirely to higher levels of imports from Canada.

Exhibit 4 shows the natural gas production, consumption, and import trends for the period of 1974-1994.

Exhibit 4 - Natural Gas Overview, 1974-1994

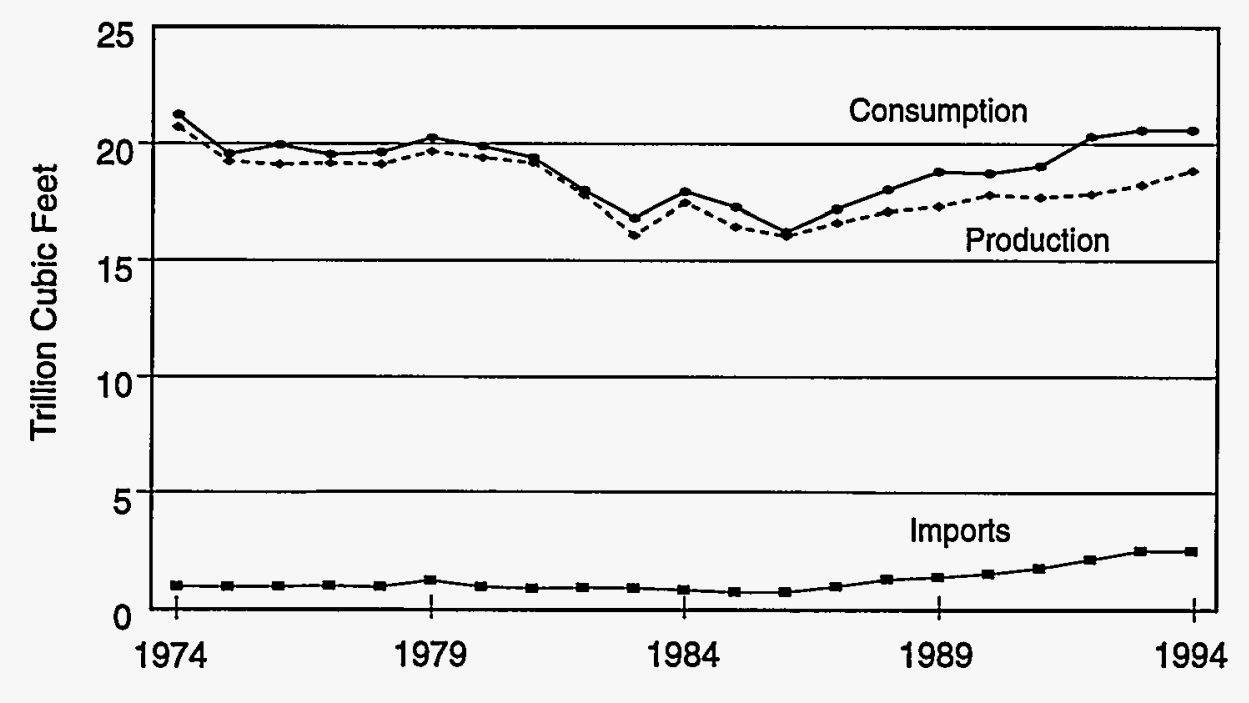


Prices: Through the early 1970 s, natural gas prices were relatively stable. Thereafter, the natural gas market underwent a period of price fluctuations brought on by deregulation and industry restructuring. The annual average wellhead price, in real terms, tended downward from a 1983 peak of $\$ 2.97$ per thousand cubic feet to a 15 -year low of $\$ 1.39$ per thousand cubic feet in 1991. Over the next 3 years, prices recovered somewhat; in 1994, the annual average wellhead price was $\$ 1.45$ per thousand cubic feet. Prices to consumers vary by region; for example, prices are lower in main producing areas, where transmission costs are lower. Prices to consumers also vary by sector. Exhibit 5 shows the natural gas wellhead prices for the period of 1974-1994.

\section{Exhibit 5 - Average Wellhead Price of Natural Gas (Real Prices in 1987 Dollars)}

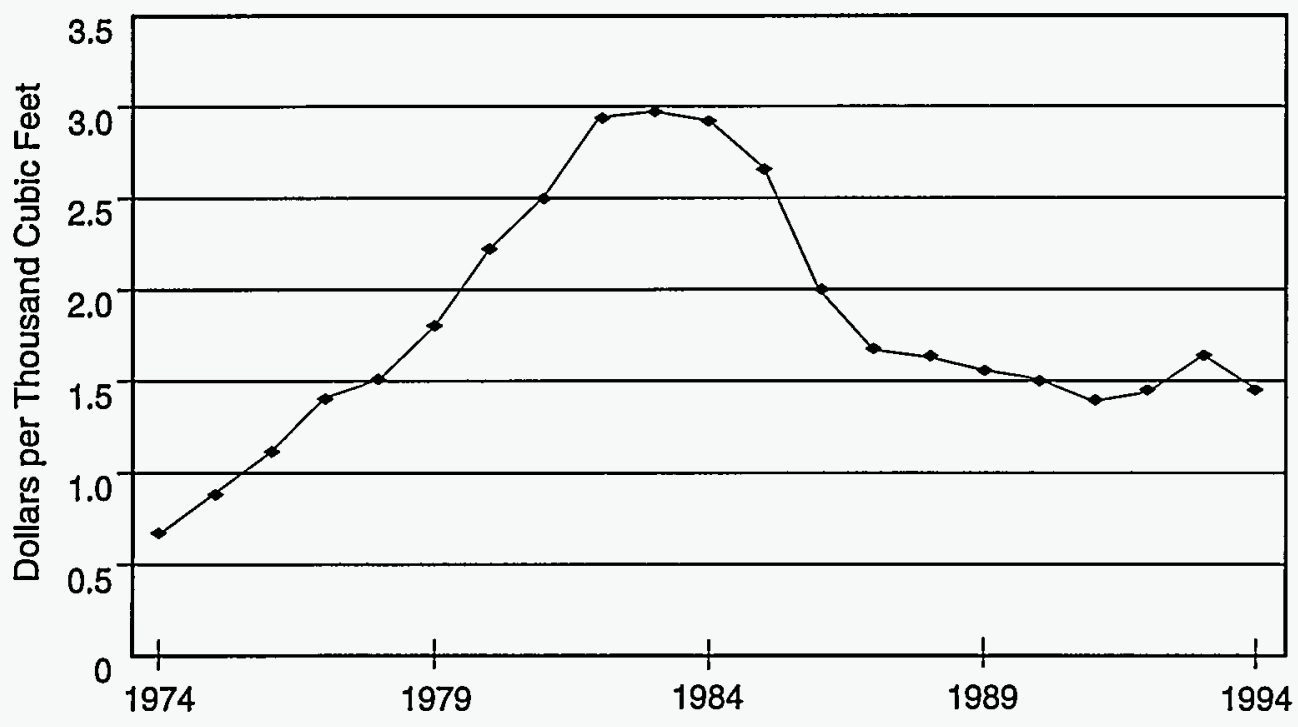

Resource Base: The total size of the "economically" recoverable natural gas resource has been estimated by the Energy Information Administration to be 1,021 Tcf with current technology, and 1,618 Tcf with advanced (2010) technology. This can be compared to the "technically" recoverable natural gas resource base estimated by the National Petroleum Council at 1,065 Tcf with current technology, and 1,294 Tcf with advanced technology. Current proved domestic natural gas reserves are $162 \mathrm{Tcf}$, including Alaska, representing an eight-year supply (1995 through 2003) at current consumption rates. Proved reserves are composed of natural gas primarily from conventional, less geographically complex reservoirs. 


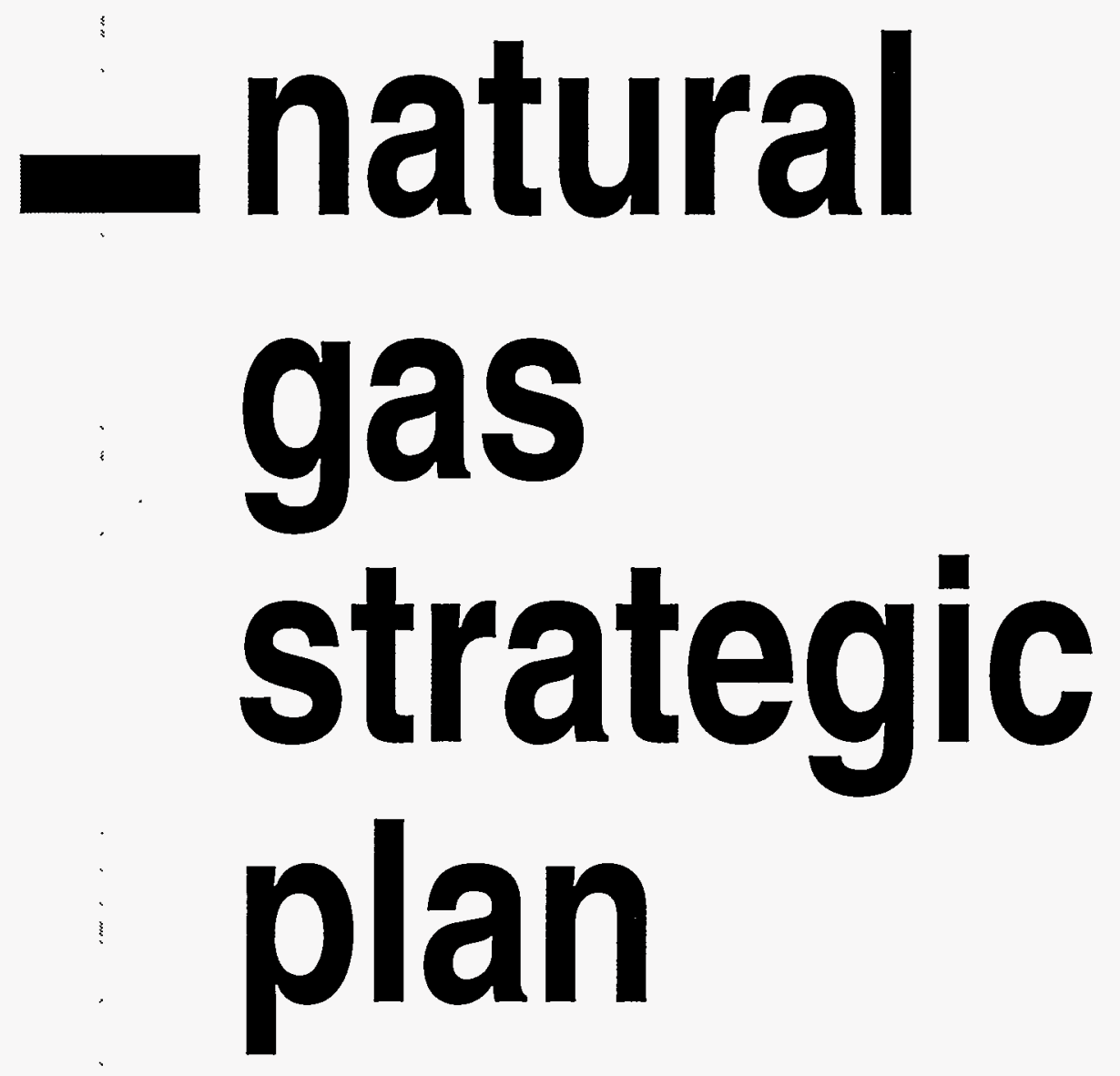

Page No.

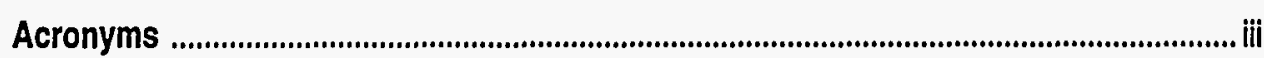

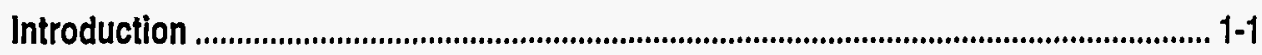

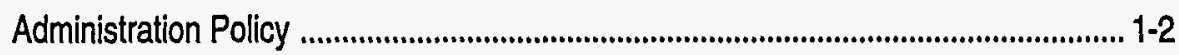

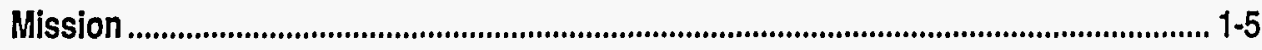

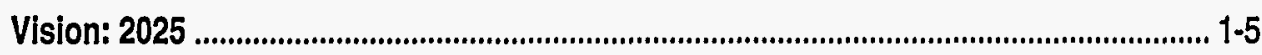

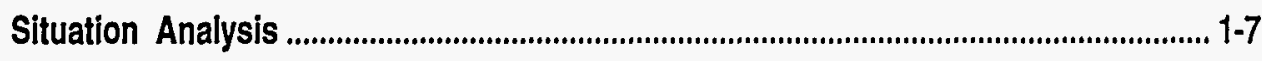

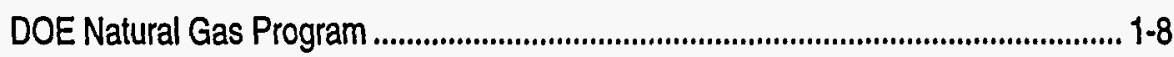

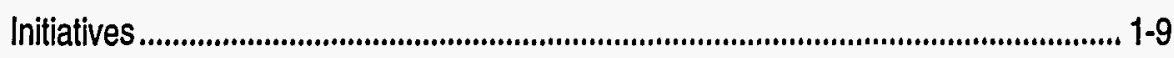

Key Stakeholders and Customers ................................................................. 1-10

Key Planning Assumptions ........................................................................................... $1-11$

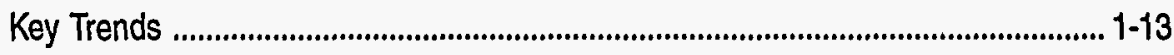

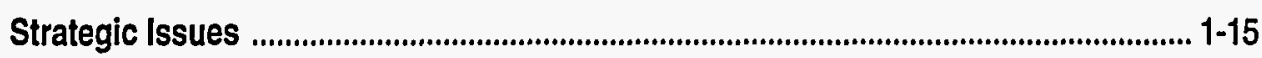

Program Goals and Strategies .......................................................................... 1-17

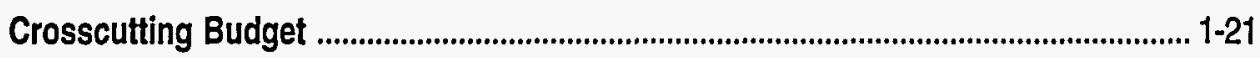




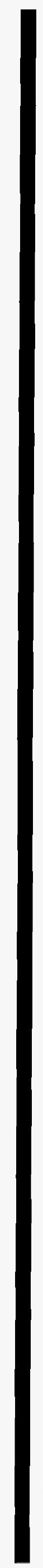




\section{acronyms}

AEO Annual Energy Outlook

DOE Department of Energy

DNGOI The Domestic Natural Gas and Oil Initiative

EIA Energy Information Administration

FY Fiscal Year

GRI Gas Research Institute

$\mathrm{NO}_{x} \quad$ Nitrogen Oxides

NPC National Petroleum Council

RD\&D Research, Development, and Demonstration

Tcf Trillion Cubic Feet

U.S. United States 



\section{introduction}

Currently, natural gas accounts for 25 percent of the energy consumed in the United States and provides significant economic, environmental and national security benefits to the Nation. Increasing our use of natural gas, primarily a domestic resource, improves the national balance of trade and encourages domestic economic growth and job creation. In addition, increased use of natural gas can reduce our reliance on imported oil, particularly in applications such as transportation vehicles or certain industrial uses where natural gas competes directly with oil. Substitution of oil with natural gas would make the U.S. less vulnerable to interruptions in foreign oil supplies or sudden, drastic increases in the price of oil. Furthermore, the use of natural gas, particularly to generate electricity, helps reduce greenhouse gas emissions.

The U.S. Department of Energy's (DOE or the Department) natural gas program is aimed at meeting simultaneously our national energy needs, reducing oil imports, protecting our environment, and improving our economy. The Natural Gas Strategic Plan for 1995 represents a Department-wide effort to articulate the key issues related to the expanded development and utilization of natural gas, and defines the roles of the Federal government and U.S. industry in partnering to accomplish the strategic goals defined. The four overarching goals of the Natural Gas Strategic Plan are to:

- Foster the development of advanced natural gas technologies,

- Encourage the adoption of advanced natural gas technologies in new and existing markets,

- Support the removal of policy impediments to natural gas use in new and existing markets, and

- Foster technologies and policies to maximize the environmental benefits of natural gas use.

DOE's proposed fiscal year (FY) 1996 budget represents a commitment to natural gas research, development, and demonstration (RD\&D) from "reservoir to end use." DOE has redirected and increased funding for its natural gas exploration, production, delivery and storage, processing, and utilization RD\&D programs, shifting funds from other energy programs to programs that will enhance efficiency and advance the role of natural gas in our domestic energy resources portfolio.

A new Department-wide planning organization for natural gas efforts has been established in DOE. This organization includes a Natural Gas Coordinating Committee (the Committee) that has been charged with ensuring that all natural gas programs are conducted with a single strategic focus to provide a united and integrated program to the gas industry and stakeholders. The Committee comprises representatives from all of the offices with responsibility for natural gas programs and policies, including the Offices of Fossil Energy, Energy Efficiency and Renewable Energy, Policy, Energy Research, Defense Programs, Nonproliferation and National Security, and Technology Partnerships and Economic Competitiveness; the Energy Information Administration (EIA); and the 
General Counsel. In order to better coordinate and integrate government and private sector gas program activities, officials from the American Gas Association and the Gas Research Institute (GRI) serve as observers on the Committee.

The Natural Gas Strategic Plan recognizes the challenges and opportunities facing increased U.S. natural gas use. These challenges and opportunities include maximizing the utilization of our domestic resource base; developing new ways in which to maximize the economic, environmental, and national security benefits offered by natural gas; and establishing policies and regulations to allow gas to compete with other fuels in new and existing markets. The strategic issues, program goals, and related strategies that are articulated in this strategic plan are intended to overcome the technology, market, policy/regulatory, and environmental barriers to increased use of natural gas in the Nation's energy future.

In the development of the Natural Gas Strategic Plan, the Committee established seven technology panels: natural gas supply, delivery and storage, power generation, industrial, residential and commercial, natural gas vehicles, and environment. Program crosscut plans for these technology areas are included in Sections 2 through 8.

\section{administration policy}

The Administration's policy is to maximize the economic, environmental, and national security benefits of natural gas use to the Nation. This policy is reflected in numerous Administration documents. In its December 1994 report, The Effect of Imports on Crude Oil and Refined Petroleum Products on the National Security, U.S. Department of Commerce recommended that the Administration continue several of its current policies to reduce U.S. reliance on imported oil, including "expanded utilization of natural gas" throughout the U.S. economy.

In December 1993, DOE issued The Domestic Natural Gas and Oil Initiative (DNGOI). One of the three Strategic Activities outlined in DNGOI is: "Stimulate Markets for Natural Gas." DNGOI states that "substituting domestically produced natural gas for energy purchased in the form of imported oil provides environmental, economic, and national security benefits to the Nation." The First Annual Progress Report of DNGOI (February 1995) provides a discussion of DOE's accomplishments during 1994 and future actions for implementation.

In October 1993, President Clinton's Climate Change Action Plan directed DOE to accelerate the commercialization of high-efficiency gas technologies, such as fuel cells, through joint ventures with utilities, research organizations, and technology developers; to fund demonstrations and market entry initiatives; and to work with the Federal Energy Regulatory Commission to continue to facilitate the implementation of regulatory reforms that will increase the availability and use of natural gas. 
Two-thirds of natural gas production in the U.S. is provided by independent producers. Independent producers, generally operators with less than 20 employees, lack the financial means to undertake RD\&D programs that can lead to more cost-effective exploration and production technologies. The deployment of advanced natural gas utilization technologies frequentiy is beyond the ability of smaller U.S. companies. Through partnership with industry, the Federal government serves as a catalyst in the development, transfer, and deployment of advanced natural gas technologies that can ensure cost-effective and reliable supply and utilization of natural gas.

In addition, the Federal government has a role in promoting the competition in natural gas markets which can provide consumers with fuel choices and may lead to lower consumer energy costs. The Federal government also works with U.S. companies to promote the use of advanced U.S. natural gas technologies in foreign markets in order to bring additional revenues and jobs into the United States. Furthermore, through partnership with business and industry, the government encourages the adoption of new technologies through purchases of new natural gas products, such as natural gas vehicles for Federal fleets, and fuel cells to power Federal facilities. 
The United States Department of Energy, in partnership with its stakeholders, undertakes and promotes activities and establishes policies to maximize the Nation's ability to supply, transport, and use natural gas to encourage economic growth, enhance national security, and improve the environment.

\section{vision: 2025}

Natural gas, a clean, domestically abundant and reliable source of energy, realizes its full potential in contributing to the Nation's economic growth, energy security, and environmental quality. Federal, State, and local actions allow for consumer choice in competitive fuel markets. Millions of consumers are using affordable and efficient natural gas technologies in their homes, businesses, industries, public facilities, and in the transportation sector. America's advanced natural gas technologies are sold and used worldwide. 


\section{$1-6$}




\section{situation analysis}

Natural gas, a clean-burning and domestically abundant fossil fuel, is an important component of the Nation's energy portfolio. Once viewed as a diminishing short-term resource, natural gas is now recognized as the fuel of choice in the long-term transition to a more sustainable energy future in the $21^{\text {st }}$ century.

After reaching its highest level of consumption in 1972 at 22 trillion cubic feet ( 25 percent higher than 1986 and 10 percent higher than 1993 consumption), natural gas use declined in the mid and late 1970 s due to the perception that the Nation would suffer long-term shortages if this level of consumption persisted. Since then, two reports, the National Petroleum Council's (NPC) The Potential for Natural Gas in the United States (1992) and the U.S. Geological Survey's National Assessment of United States Oil and Gas Resources (1995), have contributed to a much better understanding of the U.S. domestic natural gas resource base, and allayed fears of shortages. The NPC study estimated the recoverable gas resource base for the lower-48 States, including offshore, at 1,295 trillion cubic feet (Tcf), sufficient gas resources to meet U.S. demand at current levels for about 60 years. U.S. Geological Survey projections indicate recoverable onshore gas resources in the U.S. as 1,074 Tcf. Advanced technologies will play a key role in converting our Nation's gas resource base into recoverable reserves.

EIA's Annual Energy Outlook 1995 (AEO) reports a natural gas resource base of 1,021 Tcf, using current technology; and 1,619 Tcf, using advanced technology. The AEO also estimates total natural gas consumption growing from $22 \mathrm{Tcf}$ in the year 2000 to $24.6 \mathrm{Tcf}$ in 2010. Based on this reference case, it appears that there is adequate supply, provided achievable technology advances are realized. Most of the growth is projected to be in the electricity generation sector. In 1994, U.S. gas consumption totaled $20.60 \mathrm{Tcf}$, total U.S. dry gas production was $18.85 \mathrm{Tcf}$, and gas imports totaled 2.5 Tcf. Imports from Canada in 1994 were $2.4 \mathrm{Tcf}$, up 9 percent from 2.2 Tcf in 1993.

In the 1980s and 1990s, natural gas underwent a difficult transition from a heavily regulated utility service to a more competitive commodity. At the same time, the natural gas industry has become increasingly responsive to competitive market dynamics. While opportunities exist to develop further confidence in the availability and reliability of natural gas supplies, changes in federal and state public policy are recognizing the benefits of increased natural gas use. Competition is now bringing natural gas supply and demand into balance, and the recent natural gas oversupply is shrinking as the excess wellhead capacity diminishes.

Driven by increased competition and the development of advanced technologies, new markets for natural gas, which would not have been considered five years ago, are being developed. High efficiency natural gas-fueled electricity generation technology, with its environmental 


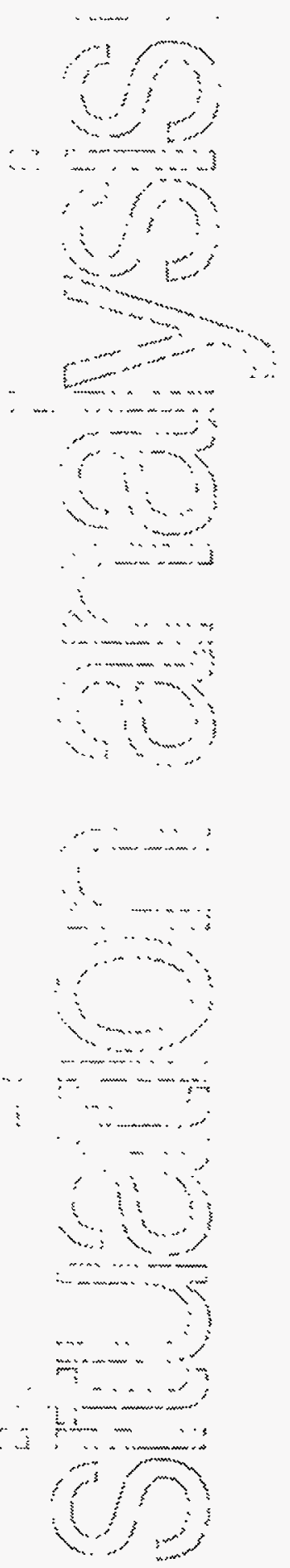

benefits, makes natural gas a player in baseload as well as peaking electricity generation. Improvements in reliability and efficiency now permit natural gas cooling technologies to be considered as an off-peak utilization strategy and for replacing chlorofluorocarbon-based cooling systems. Natural gas also has a significant role to play in the transportation sector. Environmental and energy security benefits of natural gas vehicles are becoming important factors in Federal, State, and local policy determinations.

\section{DOE natural gas program}

In the past, DOE natural gas programs were focused mainly on technology development, with only minor consideration of market and policy issues. Now, the focus of DOE natural gas programs has shifted to an integrated "systems approach," which addresses "reservoir to end use" technology needs, regulatory constraints, and market opportunities for increasing gas use. Expanding natural gas use in the U.S. presents many challenges and opportunities that include expanding the domestic resource base, developing new ways to use natural gas to maximize economic efficiency, and establishing policies and regulations to allow gas to compete with other fuels in new and existing markets. DOE's natural gas program focus is primarily on the near- and mid-term impacts on industry and consumers: reducing costs system-wide; enhancing efficient utilization of natural gas; reducing environmentally detrimental emissions; and increasing the reliability of gas supply and deliverability.

The Department also is participating in the coordination and reform of Federal, State, and local government statutes and regulations to increase competition in energy markets. DOE policy and regulatory initiatives focus on four key areas: (1) market efficiency, (2) market opportunities, (3) reducing regulatory impediments to gas use, and (4) encouraging consistency in Federal, State, and local regulatory oversight of the industry. The restructuring of the natural gas industry and the potential restructuring of the electricity industry will affect future technology development choices and also impact program budgets. The Department will need to perform further analysis of the impact Federal, State, and local regulations and electric power industry restructuring will have on the Department's ability to realize its vision for natural gas.

The Administration supports the development of advanced natural gas technologies which increase the economically efficient use of natural gas. The Federal budget has supported advanced gas technology RD\&D, thereby helping the Nation attain environmental and economic goals. DOE's natural gas budget appropriation for FY 1995 is $\$ 209$ million, and the FY 1996 request is \$267.5 million, a 28 percent increase over the FY 1995 budget. Natural gas funding 
continues to be concentrated on technology development, e.g., approximately 84 percent of the FY 1995 budget is allocated to utilization technology RD\&D.

To support this new approach, DOE is forging stronger relationships with stakeholders. Jointly funded natural gas RD\&D projects are ongoing in partnership with GRI, the Electric Power Research Institute, industry, academic institutions, the National Laboratories, and other federal agencies. These partnerships are intended to foster U.S. technical leadership and accelerate technology development and deployment, achieve national environmental goals, and define DOE's role in technology commercialization.

Environmental policies have become and will remain as one of the most important considerations undertaken by DOE when assessing the future of natural gas markets. DOE recognizes the environmental benefits of natural gas, a cleaner-burning fuel, relative to the other fossil fuels.

\section{initiatives}

The DOE Strategic Plan - Fueling A Competitive Economy, April 1994; the Administration's Climate Change Action Plan (1993); the Report of the Task Force on Alternative Fuels; the Department's Domestic Natural Gas and Oil Initiative (December 1993); and the First Annual Progress Report of DNGOI (February 1995) all contain recommendations to increase supply and utilization of natural gas. This
Natural Gas Strategic Plan and the National Energy Policy Plan, to be issued in 1995, represent further opportunities to advance the vision for natural gas. These and other recent natural gas-related initiatives of DOE are as follows:

- DOE is implementing the natural gasrelated action items in The Domestic Natural Gas and Oil Initiative. Efforts are ongoing to develop policy guidelines and a commercialization strategy for natural gas technologies.

- DOE and GRI signed a Memorandum of Understanding in May 1994, to ensure that government and industry work together in the most effective manner, and to increase communication and streamline cooperation to better coordinate industry and government research agendas.

- DOE is increasing applications of computing and information technologies throughout its natural gas programs. These information systems are resulting in reduced risks and improved decisionmaking concerning the exploration, production, transportation, and use of natural gas.

- DOE is working with other governmental agencies to enhance U.S. competitiveness in international energy markets and to promote exports of U.S. advanced gas technologies. The Secretary of Energy has led a series of trade missions to key potential markets. 
DOE continues to provide financial and analytical support for the International Energy Agency's International Centre for Gas Technology Information -- with offices located in Washington, DC, and Copenhagen, Denmark.

- DOE is implementing the natural gasrelated initiatives of the Energy Policy Act of 1992. For example, DOE has implemented a program to increase the recoverable natural gas resource base, develop advanced natural gas end-use technologies, and improve natural gas storage and deliverability to foster increased demand for natural gas.

- DOE is a key participant in addressing the role of natural gas in global climate change policy. DOE, the White House Office of Environmental Policy, and the Environmental Protection Agency currently are cooperating on developing the Administration's Global Climate Change Action Plan and the U.S. position with regard to reducing greenhouse gas emissions.

- DOE is participating in Federal and State proceedings that affect natural gas markets.

- DOE is working with State utility commissions that are reviewing their regulations applicable to natural gas companies and services.

\section{key stakeholders and customers}

Stakeholders and customers listed below have a stake in the future success of the DOE Natural Gas Strategic Plan. Their needs must be considered in the development of long-term goals and strategies.

- Natural Gas Consumers

- Agriculture Industry

- Commercial/Residential

- Industrial

- Electricity Generation

- Petrochemical Industry

- Purchase Marketers

- Transportation Industry

- Natural Gas Vehicle Users

- Natural Gas Industry

- Producers

- Operators

- Service Companies

- Processors/Refineries

- Pipeline Companies

- Gas Storage Operators

- Marketers

- Local Distribution Companies

- Gas Research Institute

- Public

- Federal, State, and Local Regulatory Agencies 
- Federal, State, and Local Governments

- U.S. Congress

- Energy and Environmental Trade Associations

- Research and Educational Community

- Environmental and Energy Efficiency Organizations

- Equipment Manufacturers and Energy Services Vendors

- Investment Community

- Foreign Governments

\section{key planning assumptions}

DOE's Natural Gas Strategic Plan consists of four major action areas: technology, market, policy/regulatory, and environment. Although the environment is a separate action area, environmental considerations are of such overarching consequence that they are a key component in all analytical areas, including markets, technology, and policy.

The following assumptions were considered in developing the goals and strategies for natural gas to meet its full potential as part of the total energy balance for achieving sustainable development. These assumptions are consistent with the outlook through the year 2010 presented in ElA's Base Case of the Annual Energy Outlook 1995, specifically with respect to supply, price, and technology development for gas and competitive fuels. $A$ revolutionary change in any of these variables would alter this strategic plan.
In addition, evolutionary technology I changes may be sufficient to affect the increase in domestic gas demand and consumption which would also likely alter this strategic plan.

\section{technology}

- During the planning period (1995 - 2025) there will be no revolutionary technological breakthroughs for competing fuels.

- The development and commercialization of new and improved natural gas exploration and production, transportation, and utilization technologies are required to support increased natural gas use.

- The Federal government will play a primary role in research and development activities that have the potential to contribute to the deployment of advanced natural gas technologies.

- Advances in drilling technology will convert an increasing portion of the domestic natural gas resource base to proven reserves.

\section{market}

- Natural gas supply and demand will be balanced by increasing competition resulting from deregulation in energy markets. 
- Natural gas will be an economically competitive source of energy.

- Domestic natural gas demand will continue to increase.

- Imports of natural gas (including liquefied natural gas) will contribute to meeting increased gas demand.

- Restructuring of the natural gas industry will stabilize, and restructuring of the electricity industry will accelerate.

- Because natural gas has environmental advantages relative to other fossil fuels, domestic and international concerns over fossil fuels creating potentially large climate change problems could increase natural gas use worldwide.

\section{policy/regulatory}

- Changes in Federal and State regulations and other policies will cause and/or incorporate restructuring of the electricity industry.

- The environmental constraints associated with resource access, siting, permitting, and construction of various facilities, including power plants, are likely to be more stringent.

- State-level energy decisionmaking and increasing competition resulting from deregulation will have an increased influence over the natural gas system from reservoir to end use.
- Restructuring in the natural gas and electricity industries will result in expansion of the gas system infrastructure and create diverse utilization markets which will contribute to the projected increase in demand for natural gas supplies.

\section{environment}

- Environmental advantages of natural gas use, relative to other fossil fuels, in reducing atmospheric emissions related to tropospheric ozone will be increasingly realized.

- Increasing natural gas use will contribute to a decrease in total atmospheric emissions of major greenhouse gases in comparison to other fossil fuels.

- State-level environmental considerations may lead to laws or regulations that will have a significant impact on the fuel use choices of consumers.

- Federal and State resirictions on onshore and offshore lands for gas production will continue in the near-term.

- Advances in science and technology will reduce substantially the environmental effects of natural gas exploration and production operations. 


\section{key trends}

An analysis of the current U.S. natural gas situation reveals the following trends.

\section{technology}

- Cooperation and partnerships are increasing between the Federal government and industry, as well as other stakeholders, on natural gas RD\&D and commercialization efforts.

- Improved exploration and production technologies are leading to increased gas production efficiency per well.

- Cost reductions resulting from improved natural gas exploration and production technologies are allowing for the production of reserves not previously economically recoverable. The known gas resource base is growing as more advanced and accurate diagnostic technologies and methods are developed.

- Environmental and efficiency considerations are playing an increasing role in the development and deployment of gas system technologies.

\section{market}

- The restructuring of the interstate gas industry is changing supply and consumption patterns, in response to increased competition, while giving consumers greater flexibility in choosing the type of gas service which best meets their needs.

- Developments in electronic information transfer and computer technology are playing an increasingly larger role in tracking of gas flows in the evolving market and reducing transaction costs.

- Driven by increased competition in natural gas and electricity markets and by new gas use applications, the demand for natural gas is expected to increase, primarily in the electricity generation, industrial, and transportation sectors.

- Despite increasing natural gas use, competition is keeping the supply and demand balance fairly constant.

- Advances in the efficiency of natural gas technologies will moderate increases in gas use, as well as stabilize seasonal consumption pattern differentials.

- Environmental and safety compliance expenditures are increasing.

- Since the late 1960 s, proven natural gas reserves in the lower-48 States have been declining. 


\section{policy/regulatory}

- The Federal government continues to support reform of regulations to encourage competition and consumer choice in energy markets.

- Emphasis on environmental considerations at the Federal, State, and local levels is growing, and environmental risk perceptions are increasingly driving regulatory policy.

\section{environment}

- Increasing globalization of environmental issues, policies, and programs are increasing natural gas use worldwide. This is particularly true with respect to atmospheric emissions.

- Governmental programs are increasingly relying on finding more effective market-driven solutions which achieve environmental goals at the least cost. The use of voluntary programs, emissions credits, and other marketbased pollution abatement activities is increasing.

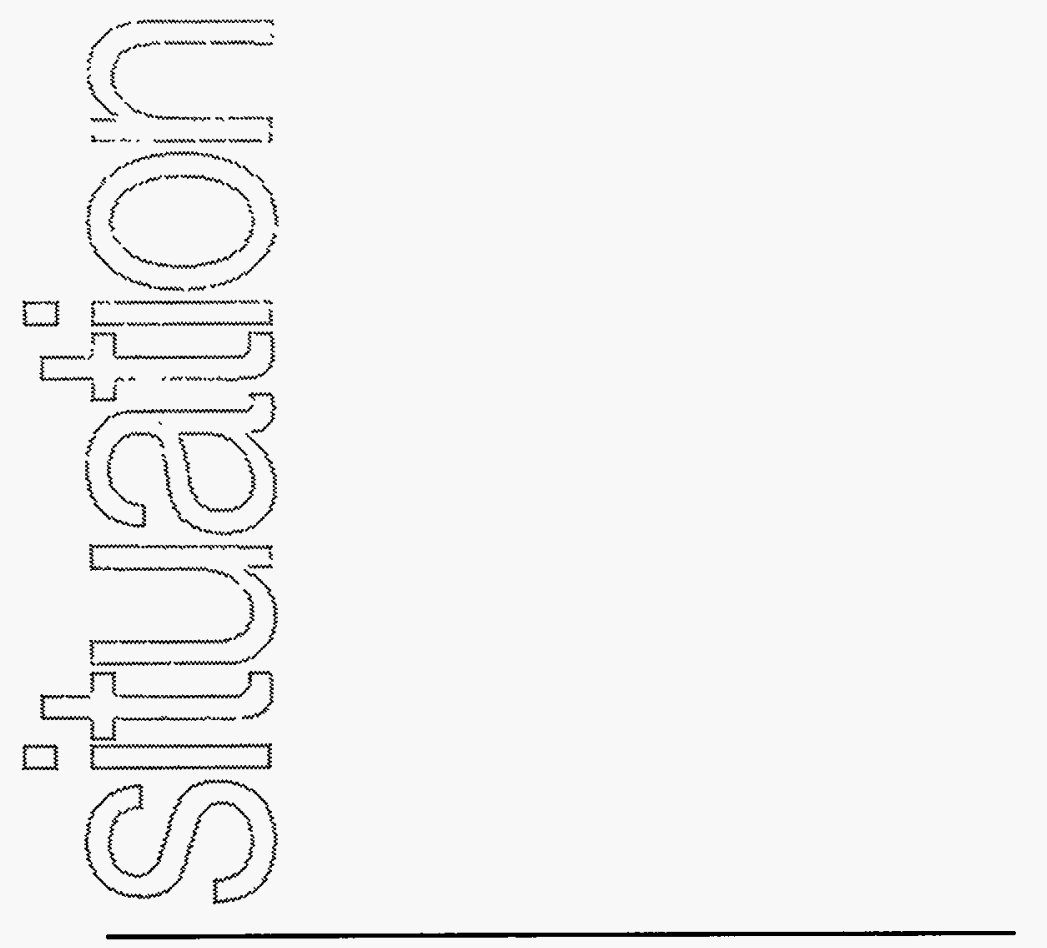




\section{strategic issues}

The strategic issues defined below represent the key barriers or obstacles that must be overcome in order to realize DOE's natural gas program vision over the planning period.

\section{technology}

- Lack of available funding in industry and government limits RD\&D and commercialization of advanced natural gas supply, storage, transmission, utilization, and environmental technologies.

- Advanced cost-effective natural gas utilization technologies are needed to meet air and water quality standards and projected stationary source emission regulations.

- Competing targets of reduced emissions (e.g., nitrogen oxides or $\mathrm{NO}_{x}$ ) and increased combustion efficiency could hinder the development of natural gas end-use technologies.

- Continuing technological innovation throughout the natural gas system is critical to maintaining and increasing production and consumption efficiencies in an actively competitive energy price environment.

- New natural gas utilization technologies, in conjunction with advances in exploration and production technologies to enhance the cost-competitiveness of gas, are needed to maintain the future use of natural gas.

- Federal RD\&D funds must be used effectively to meet the technological challenges of a $21^{\text {st }}$ century role for natural gas and the potential for increasingly competitive electricity markets to ensure that the right tradeoffs are made between the basic development of technology, new applications of technology, and the deployment (commercialization) of new technology.

\section{market}

- Perceptions of the future economics and reliability of natural gas supplies may limit the level of natural gas used in the electricity generation, industrial, and transportation sectors.

- Perceptions of future economics of natural gas supplies may limit capital investments, new markets, infrastructure maintenance and development, and new technology development.

- In the increasingly diverse and competitive natural gas industry, adequate, accurate, and timely natural gas information is not widely available to support well-informed gas market decisions. 


\section{policy/regulatory}

- Federal RD\&D funding needs to be appropriately balanced between supply, delivery and storage, utilization, and environmental programs.

- Continuing regulatory reforms that encourage competition in energy markets are needed to support the development and deployment of advanced natural gas technologies.

- Improved evaluations of total fuelcycle costs need to be developed and refined to form a reliable basis for policymaking.

- Restructuring in the natural gas industry increased the need for coordination in Federal, State, and local policies affecting natural gas from reservoir to end use.

- New policies must be developed at the Federal, State, and local government levels to allow natural gas to increase its role in our domestic energy resources portfolio.

- The effect of electricity restructuring on natural gas use and technology development is not fully understood.

\section{environment}

- A reduction in the environmental impact of natural gas exploration and production is essential to allow development of evironmentally sensitive areas with high resource potential.

- Increased understanding of atmospheric emissions chemistry is essential to designing and applying advanced natural gas utilization technologies.

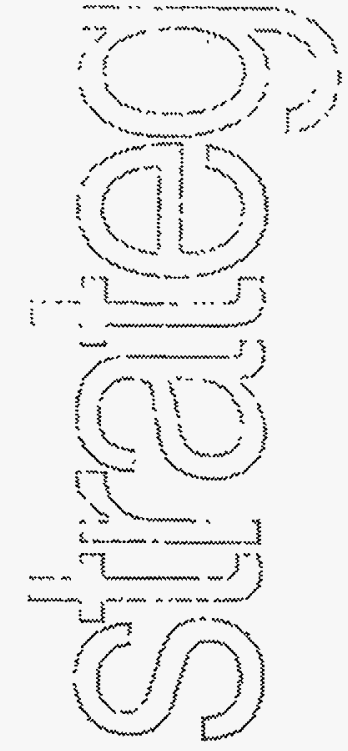




\section{program goals and strategies}

By working more closely with stakeholders, DOE will advocate economically efficient growth of natural gas markets.

The four overarching goals of the Natural Gas Strategic Plan are to: (1) foster the development of advanced natural gas technologies, (2) encourage the adoption of advanced natural gas technologies in new and existing markets, (3) support the removal of policy impediments to natural gas use in new and existing markets, and (4) foster technologies and policies to maximize the environmental benefits of natural gas use. These goals and corresponding strategies are set out below.

\section{technology}

Goal: DOE will foster the development of advanced natural gas technologies to explore, produce, store, transport, and use natural gas cleanly, more efficiently, and more extensively in the electricity generation, industrial processes, transportation, and commercial and residential sectors.

\section{Strategies:}

- Promote and participate in accelerated natural gas technology RD\&D to allow U.S. industry to meet timetables and provisions for air quality goals.

- Promote and participate in the development of cost-effective advanced natural gas supply technologies and systems to ensure adequate supplies of natural gas.

- Support development and deployment of advanced utilization technologies, including gas turbine systems, fuel cells, natural gas vehicles, building applications, and cleaner, more efficient industrial systems.

- Develop advanced natural gas technologies and methodologies to increase pipeline deliverability.

- Promote increased utilization of advanced computing and information technologies to fully integrate the natural gas system. 


\section{market}

Goal: DOE will encourage increased use of natural gas in new and existing markets in the supply, electricity generation, industrial, transportation, and commercial and residential sectors.

\section{Strategies:}

- Pursue cooperative programs between indusiry and government to increase public awareness of the long-term availability, reliability, and safety of natural gas use.

- Advocate the development of a fully integrated commercial natural gas transportation infrastructure.

- Support/encourage adoption of advanced natural gas technologies in all end-use market sectors.

- Foster the development of increased, economically competitive U.S. natural gas supplies, including longer-term unconventional resources to supplement conventional production, to displace oil imports.

- Identify strategic market areas for new and expanding natural gas use, and demonstrate cost-effective storage and delivery technologies and methodologies to optimize the economics of gas storage development and operations.
- Develop timely, accurate, and reliable reservoir-to-end use natural gas deliverability information systems to support the natural gas markets.

\section{policy/regulatory}

Goal: DOE will identify, analyze, and support the removal of regulatory and other policy impediments to efficient production, transportation, and use of natural gas in the electricity generation, industrial processes, transportation, and commercial and residential sectors.

\section{Strategies:}

- Support development of better communication systems between Federal, State, and local decisionmakers and industry to provide timely information.

- Work collaboratively with State and local decisionmakers to ensure complimentary Federal, State, and local policies that help achieve national goals.

- Participate in Federal and State proceedings that affect the use of natural gas in the electricity generation, indusirial processes, transportation, and commercial and residential sectors.

- Undertake study of the effect of electricity industry restructuring on natural gas demand and reliability. 


\section{environment}

Goal: DOE will foster advanced technologies and policies that minimize the impact of exploration and production operations and maximize the environmental benefits of natural gas use in the electricity generation, industrial processes, transportation, and commercial and residential sectors.

\section{Strategies:}

- Promote increased public understanding of the environmental benefits of natural gas use in achieving the Nation's clean air goals.
- Promote and participate in the development of advanced exploration and production technologies to permit natural gas recovery in environmentally sensitive areas.

- Promote and participate in the development of better understanding of atmospheric emissions chemistry to contribute to better utilization technology development.

- Promote and participate in the development of advanced natural gas technologies to reduce methane losses within the natural gas system from reservoir to end use. 


\section{crosscutting budget}

DOE's natural gas RD\&D program activities crosscut the Offices of Fossil Energy, Energy Efficiency and Renewable Energy, and Energy Research. Specific activities are carried out and funded either independently by each Office or jointly, depending on the Office mission, program focus, crosscutting programmatic relationships, and budgetary considerations. These activities are grouped under the program budget categories of Exploration and Production, Delivery and Storage, Utilization, and Environmental/Regulatory Impact.

(Dollars in Million)

\begin{tabular}{|c|c|c|c|c|c|c|c|c|c|c|c|c|c|c|}
\hline \multirow[b]{2}{*}{ Natural Gas Program Sectors } & \multicolumn{3}{|c|}{ Department-Wide } & \multirow[b]{2}{*}{$\begin{array}{c}\text { GRI } \\
\text { 1995 } \\
\text { Planned } \\
\end{array}$} & \multirow[b]{2}{*}{$\begin{array}{c}\text { GRI } \\
\text { 1996 } \\
\text { Proposed }\end{array}$} & \multicolumn{3}{|c|}{ Fossil Energy } & \multicolumn{3}{|c|}{ Energy Efficiency } & \multicolumn{3}{|c|}{ Energy Research } \\
\hline & \begin{tabular}{|l|}
$F Y 94$ \\
Actual \\
\end{tabular} & $\begin{array}{c}\text { FY95 } \\
\text { Approp.' }\end{array}$ & $\begin{array}{l}\text { FY 96 } \\
\text { Cong. } \\
\text { Req. }\end{array}$ & & & $\begin{array}{l}\text { FY94 } \\
\text { Actual }\end{array}$ & $\begin{array}{l}\text { FY } 95 \\
\text { Approp. }\end{array}$ & $\begin{array}{l}\text { FY } 96 \\
\text { Cong. } \\
\text { Req. }\end{array}$ & $\begin{array}{l}\text { FY } 94 \\
\text { Actual }\end{array}$ & $\begin{array}{l}\text { FY 95 } \\
\text { Approp. }\end{array}$ & $\begin{array}{l}\text { FY } 96 \\
\text { Cong. } \\
\text { Req. }\end{array}$ & $\begin{array}{l}\text { FY } 94 \\
\text { Actual }\end{array}$ & $\begin{array}{l}\text { FY } 95 \\
\text { Approp. }\end{array}$ & $\begin{array}{l}\text { FY } 96 \\
\text { Cong. } \\
\text { Req. }\end{array}$ \\
\hline Exploration and Produclion & 22.0 & 27.9 & 40.4 & 52.5 & 57.0 & 15.0 & 20.7 & 33.0 & - & - & - & 7.0 & 7.2 & 7.4 \\
\hline Delivery and Storage & 1.0 & 1.1 & 3.1 & 25.7 & 27.2 & 1.0 & 1.1 & 3.1 & - & - & - & - & - & - \\
\hline Utilization & 148.3 & 174.7 & 216.2 & 88.0 & 89.0 & 76.4 & 91.6 & 104.3 & 67.4 & 78.4 & 107.1 & 4.5 & 4.7 & 4.8 \\
\hline Combustion Systems & 8.3 & 7.2 & 7.5 & 24.3 & 24.2 & - & - & - & 4.0 & 2.7 & 2.9 & 4.3 & 4.5 & 4.6 \\
\hline HeatPumps & 7.3 & 8.8 & 6.8 & 5.4 & 3.4 & - & - & - & 7.3 & 8.8 & 6.8 & - & - & - \\
\hline Gas Turbines & 35.0 & 56.4 & 67.4 & 2.3 & 2.1 & 20.7 & 37.7 & 44.0 & 14.3 & 18.7 & 23.4 & - & - & - \\
\hline Natural Gas Vehicles & 24.4 & 27.6 & 26.7 & 11.8 & 11.4 & - & - & - & 24.4 & 27.6 & 26.7 & - & - & - \\
\hline Fuel Cells & 54.5 & 55.4 & 78.5 & 3.9 & 4.5 & 51.1 & 49.6 & 55.4 & 3.4 & 5.8 & 23.1 & - & - & - \\
\hline Gas-10-Liquids & 4.6 & 4.3 & 4.9 & - & - & 4.6 & 4.3 & 4.9 & - & - & - & - & - & - \\
\hline Other & 14.2 & 15.0 & 24.4 & 40.3 & 43.4 & - & - & - & 14.0 & 14.8 & 24.2 & 0.2 & 0.2 & 0.2 \\
\hline EnvironmentaVRegulatory Impact & 4.9 & 5.5 & 7.8 & 9.7 & 9.7 & 2.4 & 3.0 & 5.4 & - & - & - & 2.5 & 2.5 & 2.4 \\
\hline TOTAL & 176.2 & 209.2 & 267.5 & 175.9 & 182.9 & 94.8 & 116.4 & 145.8 & 67.4 & 78.4 & 107.1 & 14.0 & 14.4 & 14.6 \\
\hline
\end{tabular}

'Appropriation

${ }^{2}$ Congressional

${ }^{3}$ Request

4 Office of Energy Efficiency and Renewable Energy 
(Dollars in Million)

\begin{tabular}{|c|c|c|c|c|}
\hline & Department-Wide & Fossil Energy & Energy Efficiency & Energy Research \\
\hline Natural Gas Program Sectors & $\begin{array}{l}\text { FY } 96 \\
\text { Cong. }{ }^{1} \\
\text { Req. }\end{array}$ & $\begin{array}{l}\text { FY } 96 \\
\text { Cong. } \\
\text { Req. }\end{array}$ & $\begin{array}{l}\text { FY } 96 \\
\text { Cong. } \\
\text { Req. }\end{array}$ & $\begin{array}{l}\text { FY } 96 \\
\text { Cong. } \\
\text { Req. } \\
\end{array}$ \\
\hline Exploration and Production & 40.4 & 33.0 & - & 7.4 \\
\hline Delivery and Storage & 3.1 & 3.1 & - & - \\
\hline Utilization & 216.2 & 104.3 & 107.1 & 4.8 \\
\hline Combustion Systems & 7.5 & - & 2.9 & 4.6 \\
\hline Heat Pumps & 6.8 & - & 6.8 & - \\
\hline Gas Turines & 67.4 & 44.0 & 23.4 & - \\
\hline Natural Gas Vehicles & 26.7 & - & 26.7 & - \\
\hline Fuel Cells & 78.5 & 55.4 & 23.1 & - \\
\hline Gas-to-Liquids & 4.9 & 4.9 & - & - \\
\hline Other & 24.4 & - & 24.2 & 0.2 \\
\hline EnvironmentaVRegulatory Impact & 7.8 & 5.4 & - & 2.4 \\
\hline TOTAL & 267.5 & 145.8 & 107.1 & 14.6 \\
\hline
\end{tabular}

'Congressional

${ }^{2}$ Request

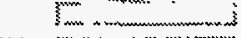

3
3
$\cdots$

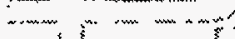

;n rm in a

(

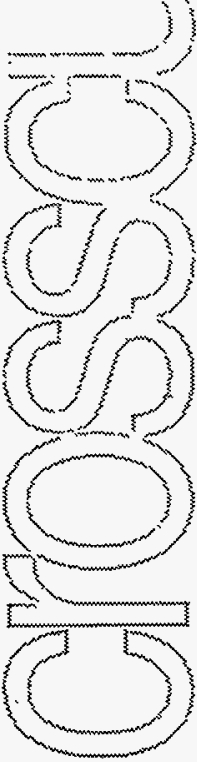


(Dollars in Million)

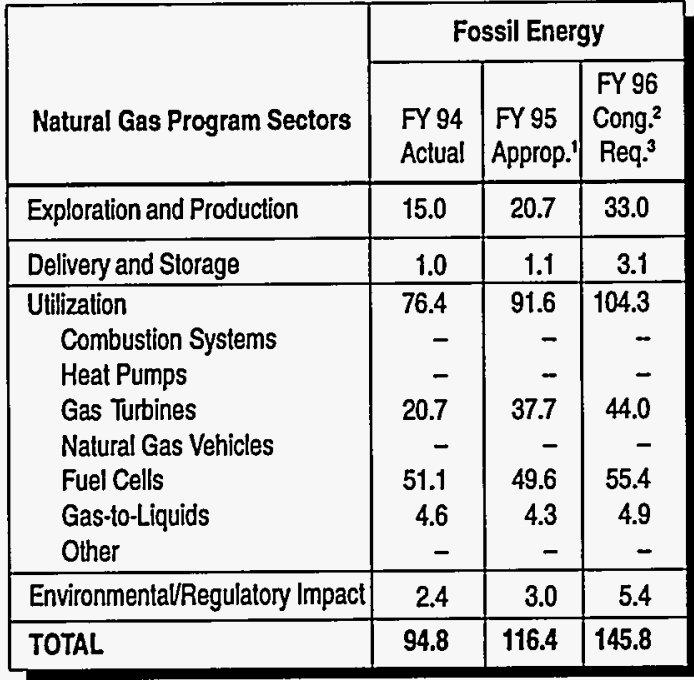

\begin{tabular}{|c|c|c|c|c|}
\hline \multirow{2}{*}{$\begin{array}{l}{ }^{1} \text { Appropriation } \\
{ }^{2} \text { Congressional } \\
{ }^{3} \text { Request }\end{array}$} & \multirow[b]{2}{*}{ Natural Gas Proaram Sectors } & \multicolumn{3}{|c|}{ Energy Efficiency } \\
\hline & & $\begin{array}{l}\text { FY } 94 \\
\text { Actual }\end{array}$ & $\begin{array}{l}\text { FY } 95 \\
\text { Approp. }\end{array}$ & $\begin{array}{l}\text { FY } 96 \\
\text { Cong. } \\
\text { Req. }\end{array}$ \\
\hline & Exploration and Production & - & - & - \\
\hline & Delivery and Storage & - & - & - \\
\hline & $\begin{array}{l}\text { Utilization } \\
\text { Combustion Systems } \\
\text { Heat Pumps } \\
\text { Gas Turbines } \\
\text { Natural Gas Vehicles } \\
\text { Fuel Cells } \\
\text { Gas-to-Liquids } \\
\text { Other }\end{array}$ & $\begin{array}{r}67.4 \\
4.0 \\
7.3 \\
14.3 \\
24.4 \\
3.4 \\
-\overline{0}\end{array}$ & $\begin{array}{r}78.4 \\
2.7 \\
8.8 \\
18.7 \\
27.6 \\
5.8 \\
14 . \overline{8}\end{array}$ & \begin{tabular}{r|}
107.1 \\
2.9 \\
6.8 \\
23.4 \\
26.7 \\
23.1 \\
$24 . \overline{2}$
\end{tabular} \\
\hline & EnvironmentalRegulatory Impact & - & - & - \\
\hline & TOTAL & 67.4 & 78.4 & 107.1 \\
\hline
\end{tabular}

\begin{tabular}{|l|r|r|r|}
\hline \multirow{2}{*}{ Natural Gas Program Sectors } & \multicolumn{3}{|c|}{ Energy Research } \\
\cline { 2 - 4 } & FY 94 & FY 95 & $\begin{array}{l}\text { FY 96 } \\
\text { Cong. } \\
\text { Approp. } \\
\text { Req. }\end{array}$ \\
\hline Extual & 7.0 & 7.2 & 7.4 \\
\hline Delivery and Storage & - & - & - \\
\hline Utilization & 4.5 & 4.7 & 4.8 \\
Combustion Systems & 4.3 & 4.5 & 4.6 \\
Heat Pumps & - & - & - \\
Gas Turbines & - & - & - \\
Natural Gas Vehicles & - & - & - \\
Fuel Cells & - & - & - \\
Gas-to-Liquids & - & - & - \\
Other & 0.2 & 0.2 & 0.2 \\
\hline EnvironmentalRegulatory Impact & 2.5 & 2.5 & 2.4 \\
\hline TOTAL & 14.0 & 14.4 & 14.6 \\
\hline
\end{tabular}



natural

gas

supply 

Page No.

Acronyms ............................................................................................................................. ii

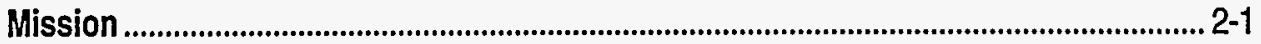

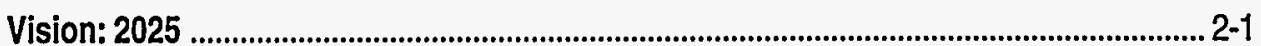

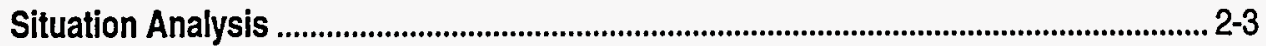

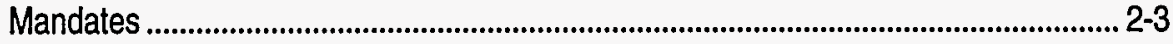

Program Relationships .............................................................................................. 2-3

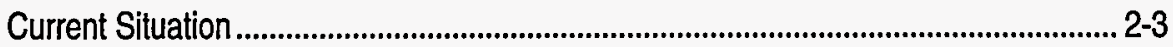

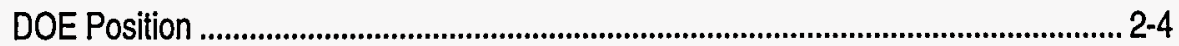

Stakeholder Considerations ........................................................................................ 2-5

Key Trends ..................................................................................................................... 2-7

Key Planning Assumptions ............................................................................... 2-8

Strategic Issues ............................................................................................................ 2-11

Program Goals and Strategies ......................................................................................... 2-15

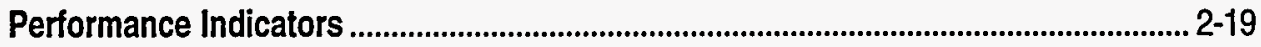

Program Overview .............................................................................................................. 2-23

Program Activities Summary ................................................................................. 2-23

Changes from Previous Plan ............................................................................... 2-24

FY 1994-1996 Budget Summary ...................................................................... 2-25

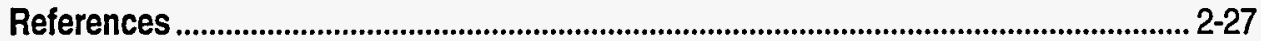




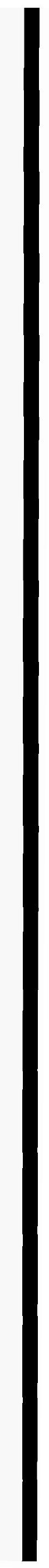




\section{acronyms}

DOE Department of Energy

EIA Energy Information Administration

E\&P Exploration and Production

FY Fiscal Year

RD\&D Research, Development, and Demonstration

Tof Trillion Cubic Feet 



\section{mission}

DOE's Natural Gas Supply program, in partnership with industry and stakeholders, undertakes activities and promotes policies to ensure an adequate long-term supply of quality natural gas as an economically viable option in a porttolio of fuels by researching, developing, demonstrating, and fostering the deployment of cost-effective exploration, production, and processing technologies and systems.

\section{vision: 2025}

The development and application of advanced exploration, production, and processing technologies have resulted in abundant domestic natural gas supply with the ultimate recoverable resource base approaching 2,250 trillion cubic feet (Tcf) in 2025'. Natural gas is economically recoverable from all types of geologically complex, gas-bearing formations. U.S. technology still sets the pace for cost-effective production of natural gas worldwide. Natural gas is an economically competitive option for transportation, power generation, and industrial processes and has helped reduce oil imports primarily through fuel-switching for electric power generation and conversion to competitively priced liquid transportation fuel. 
2-2 


\section{m situation analysis}

\section{mandates}

The primary program drivers are the Departmental Strategic Plan, the Natural Gas Strategic Plan and Multi-Year Program Crosscut Plan, FY 1994-1999, The Domestic Natural Gas and Oil Initiative, the Energy Policy Act of 1992, the Climate Change Action Plan, and the recommendations included in the National Petroleum Council Study, titled Research, Development, and Demonstration Needs of the Oil and Gas Industry.

\section{program relationships}

DOE's Natural Gas Supply program is administered through the Offices of Fossil Energy, Energy Efficiency and Renewable Energy, Energy Research, and Policy. For the Office of Fossil Energy, individual projects are implemented through the Morgantown Energy Technology Center, Morgantown, West Virginia; and the Pittsburgh Energy Technology Center, Pittsburgh, Pennsylvania. Projects are cost-shared with industry at varying levels of participation depending on the type of project and the associated risk, i.e., industry cost-sharing percentage is lower for basic research projects and is higher for technology demonstration projects.

\section{current situation}

High resource estimates have caused natural gas to be regarded as an abundant and economically competitive domestic energy resource. This perception, along with the increasing competitiveness of natural gas, has contributed to increased demand for natural gas throughout the United States. The total size of the "economically" recoverable natural gas resource base has been estimated by the Energy Information Administration (EIA) to be 1,021 Tcf with current technology, and 1,619 Tcf with advanced (2010) technology. This can be compared to the "technically" recoverable natural gas resource base estimated by the National Petroleum Council ${ }^{3}$ at 1,065 Tcf with current technology, and 1,295 Tct with advanced technology.

Current proved domestic natural gas reserves are $162 \mathrm{Tcf}^{4}$, including Alaska, representing a remaining on-the-shelf-supply of eight years (1995 through 2003) at current consumption rates ${ }^{5}$. Proved reserves are composed of natural gas primarily from conventional, less geologically complex reservoirs.

The recent restructuring of the U.S. natural gas industry is continuing and the overall effect on technology advancement has been a reduction in the amount of capital available to the industry for research and development. Environmental compliance and other operating costs are increasing; therefore, these higher costs combined with low wellhead prices are reducing operating profit margins which are resulting in premature abandonments of natural gas wells and leases. 


\section{DOE position}

The Department supports the development and deployment of advanced and new natural gas supply related products. The objective of the DOE natural gas program is to remove barriers impeding progress toward ensuring that natural gas remains an economically viable option in a portfolio of fuel options. The program includes exploration, production, and processing research, development, and demonstration (RD\&D), and extraction and processing related environmental research. In order to better serve the needs of DOE stakeholders, the Department-wide program now utilizes an integrated "systems approach" to address the issues related to technology, market, policy, and the environment from the reservoir to ultimate consumption.

The systems approach adopted by the Department for natural gas activities also applies to the supply "subsystem." This approach consists of stages beginning with identification and characterization of the natural gas resource, through exploration and discovery to further characterization, development, extraction, and processing. Each sector of the supply subsystem has a unique set of issues and barriers that must be addressed in order to increase the efficiency of the supply subsystem and to ensure abundant, long-term availability of quality natural gas. The supply subsystem focuses on five key areas: exploration, production, processing, the environment, and technology transfer. The Department is committed to improving and expanding the integration, coordination, and partnering of Federal and non-Federal efforts in these areas.

Furthermore, the Department's traditional natural gas supply program has been expanded to actively seek additional partnerships with stakeholders, such as the Gas Research Institute, Petroleum Technology Transfer Council, National Advanced Drilling and Excavation Technology program, Interstate Oil and Gas Compact Commission, and the North American Coalbed Methane Forum. The objectives of these partnerships are to increase the effectiveness of the DOE program, and to increase the synergy between the Department and these efforts. The Department is equally committed to increasing the synergy in-house between the fundamental geoscience and environmental research and the applied aspects of RD\&D and deployment. Integrating and optimizing the Federal efforts (see Federal Government on page 2-6) with non-Federal efforts is at the core of this goal.

In July 1994, the Secretary of Energy asked the National Petroleum Council to identify and prioritize the RD\&D needs of the oil and gas industry, both upstream and downstream. The National Petroleum Council pursued the following activities: (i) assessing the current RD\&D priorities of the industry; (ii) defining existing, unique capabilities of the National Laboratories in priority needs and to enhance technology 
transfer to the industry; (iii) analyzing the broad areas in which industry/government cooperative research may be most beneficial; and (iv) examining the process and mechanisms for cooperative research and technology transfer programs. The results of this work will be used by the Department as input to setting priorities and goals for the natural gas RD\&D program.

\section{stakeholder considerations}

Natural Gas Producers: This group can be divided into two main categories: major integrated companies, which generally operate both domestically and internationally; and independent producers, which generally operate domestically. Major integrated companies have historically funded most of the domestic oil and gas research. In recent years, major companies have reduced their spending on research as part of their overall downsizing of domestic operations. ${ }^{6}$ Small and mid-sized independent producers are generally considered as having less access to technology and more limited financial resources when compared to the larger organizations. Currently, 66 percent of domestic natural gas production is provided by independent producers. Many of these companies employ less than 20 people.
Service Sector: Many exploration, production, and processing activities are conducted through the service sector because most individual gas producers do not own their own drilling rigs, pump trucks, logging tools, or simulation models but contract much of this work out to service companies. The service sector is in turn supported by the equipment sector, which provides casing, pumps, pigs and other products, such as software. A DOE study conducted by the Interstate Oil and Gas Compact Commission ${ }^{7}$ concluded that smaller independent producers generally receive most of their information on technology from vendors and consultants.

Industry Organizations: Professional societies and industry associations disseminate information on technology products and methodology to researchers, service companies, consultants, producers and operators. They also aid in identifying potential partnerships for specific projects. Organizations that perform or sponsor research such as the Gas Research Institute, and the American Gas Association have a niche role in developing research products. Other organizations, such as the Petroleum Technology Transfer Council, Production Research Forum, the Drilling Engineering Association, and the Gas Utilization Forum, coordinate and foster industry as well as federal research support and participation. 


\section{Environmental Organizations:}

Environmental interest groups and agencies monitor the wastes and produced fluids from exploration and production (E\&P) operations and processing, and are interested in seeing the industry continue to improve its protection of the environment. They also promote and support concepts and ideas that improve and protect the environment, such as the substitution of natural gas for oil.

Federal Government: In addition to DOE, various U.S. government agencies [e.g., Department of the Interior (Bureau of Land Management, Bureau of Indian Affairs, Minerals Management Service, U.S. Geological Survey), Department of Transportation (U.S. Coast Guard), Department of Agriculture (Forest Service, Fish and Wildlife Service), and the U.S. Environmental Protection Agency] interact with various sectors of the supply area. Improved coordination and efficiency are of interest to all stakeholders, as some have responsibility for regulation, while others have responsibility for supply research and development, technology development, and related environmental and economic policy.
State Governments: State agencies have responsibilities and jurisdiction over many important aspects of E\&P operations and production allowables. The Interstate Oil and Gas Compact Commission, a voluntary association of producing state regulators, actively seeks to support sensitive State environmental regulations. The Energy Council, an association of energy legislators, actively seeks to support a balanced energy portfolio.

Foreign Companies: Geographically adjacent natural gas producers in Canada and Mexico export natural gas to the U.S. and can also import U.S. technology. More distant producers export liquefied natural gas to our coastal receiving terminals.

Investment Community: The investment community is concerned with reducing the risk of financing natural gas-related activities such as development of resources, commercializing exploration, production, and processing technologies, and construction of associated facilities.

Other: Resource assessments and characterization, database development, and modeling are conducted by the geological surveys, universities, consultants and other vendors. 


\section{key trends}

\section{technology}

- Technological advances continue to enhance industry's ability to find and develop new natural gas reserves at competitive prices.

- Technological advances continue to minimize the impact of natural gas exploration, production, and processing operations on the environment.

- Industry interest in exploration technology has increased, and recent technological advances in deepwater drilling have opened up additional offshore areas as potential new discovery sites.

- Reducing the costs of exploration, production, and processing operations has been a key driver for research, development, and demonstration projects. However, future advances will likely be smaller due to declining investments.

- Significant technological advances for natural gas processing are resulting in cost-competitive technologies for the production of high quality fuels and premium chemicals.

- Natural gas company RD\&D spending has been and will continue to be constrained by low prices and industry restructuring trends.

\section{market}

- Low natural gas wellhead prices are reducing industry investment in new technology development, which may adversely affect long-term gas supplies.

- Natural gas demand continues to increase, while the level of drilling activities remain subject to price swings.

- Long-term gas supply contracts are stabilizing producer revenues, which in turn are needed for planning exploration and development, which increases gas reliability.

- Natural gas imports will continue to increase modesily, mostly from Canada.

\section{policy/regulatory}

- The Administration continues to support natural gas as an increasingly important fuel option in the U.S. energy supply portiolio.

- The Administration continues to promote and enter into partnerships with the natural gas industry to develop advanced natural gas technologies.

\section{environment}

- Environmental regulations and ensuing compliance costs continue to increase.

- Industry interest in environmental compliance technology continues to increase. 
- There is growing interest and support for risk-based environmental regulation.

- Operators continue to need information about new environmental regulations and their requirements, and technical and economic options for compliance approaches and technologies.

\section{key planning assumptions}

\section{technology}

- Deployment of advanced technology for natural gas E\&P operations will reduce exploration and production costs, and result in stable long-term supply.

- Continued technology advances will be needed, as future natural gas supplies will come from both deeper and more geologically complex reservoirs requiring specialized technology.

- As more "low quality" natural gas is produced, advanced technology will be needed to remove larger quantities of contaminants.

- DOE and its stakeholders will continue to enter into partnerships in the development of more environmentally benign exploration, production, and processing technologies.

\section{market}

- U.S. natural gas demand will increase to 22 Tcf in 2000 and 24.6 Tcf in 2010, as projected by the Energy Information Administration's Annual Energy Outlook 1995.

- The supply of natural gas from resenoirs is sustainable over the long-term.

- Increased demand for natural gas will deplete the highest quality, most easily accessible resources more rapidly. This will cause greater interest in that part of the resource base which is: constrained and/or under moratoria, harder to produce or more difficult to explore for (i.e., fractured reservoirs), of lower than acceptable quality, and/or more remote from the marketplace.

- DOE RD\&D programs, in coordination with other Federal and non-Federal efforts, will result in advanced technology that will help natural gas remain competitive as a fuel option in the United States.

- As the major producers shift their interests overseas, the smaller domestic producers most likely will be the companies that develop the low permeability tight gas reservoirs and fractured reservoirs, which currently have marginal economics or present exploration difficulties. 
- Demand will increase for more environmentally acceptable transportation fuels that are economically competitive with petroleum-derived fuels.

\section{policy/regulatory}

- The Administration's policy to maximize cost-effective use of natural gas will

continue, thereby increasing the need for greater long-term supply.

- Areas currently under federal E\&P moratoria (including the Arctic National Wildlife Refuge and offshore areas) will not be developed.

\section{environment}

- Environmental concerns will continue to limit exploration of ecologically sensitive exploration areas.

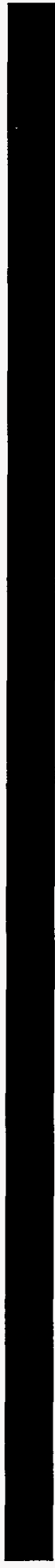




\section{strategic issues}

\section{technology}

- Advanced technology will be required to help natural gas continue as a cost-competitive energy source into the next century.

- Advanced natural gas technology is needed to offset the decline in production expected after the technical limits of currently available technology have been reached.

- The applicability of a technology tested under one set of geologic/reservoir conditions to another set of conditions may require refinements based on localized geologic and engineering evaluations in order to maximize new applications of the technology.

- The diverse nature of natural gas reservoirs (onshore, offshore, low permeability formations, deep reservoirs, Devonian shale, coalbed methane) and associated exploration, production, and processing problems result in the need to address many divergent problems simultaneously.

- Decreasing investments in technology RD\&D by the private and public sector adversely affect the rate of technology development.

- Low natural gas prices could prevent industry from achieving the projected technology advancement rates and incremental supply and reserves attributed to application of advanced technology.

- Supply will come from a variety of geologic settings, each possessing a unique set of technological barriers which must be overcome in order to ensure long-term supply.

- The cost of exploration, production, and processing technologies must be reduced in order to ensure an abundant supply.

- New technology may be beyond the financial capacity of undercapitalized producers.

Cost-effective second generation advanced technologies are needed for their widespread deployment.

\section{market}

- Continued low wellhead prices and uncertainty about future wellhead prices may lead to increased well abandonment.

- Lack of timely information on the availability and performance of new technologies by operators, the service sector, equipment vendors, and consultants reduces the deployment rate of new and/or advanced technologies. 
- Low prices and uncertainty about future prices inhibit new projects (e.g., new wells) and/or advanced technology.

- Unless gas producers, especially independents, deploy new and advanced E\&P technologies, and explore new domestic frontiers, adequate projected supply levels may not be realized.

- Market deployment of DOEsponsored technologies and products must be expanded in order to help achieve the production levels required to meet long-term gas demand.

- Advanced technology must be adapted to current and foreseeable low-to-moderate wellhead prices and show tangible benefits in that price environment.

\section{policy/regulatory}

- Future economic and tax incentives may be needed to assure availability of gas supplies from unconventional, low quality, remote, and other marginal resources, and to stimulate advanced technology development and deployment.

- The historical rate of technological advancement includes the traditional investment in RD\&D by the Federal government. Therefore, continued government RD\&D and other gasrelated program elements with requisite near-term funding are critical to maintaining a viable natural gas industry and ensuring long-term gas supplies for energy security.

- Increased Federal funding for supply RD\&D is needed to offset the decline in investment by the private sector in natural gas supply RD\&D programs. 


\section{environment}

- Rising environmental compliance costs increase the cost of exploration, production, and processing of natural gas, which can lead to lower profit margins, premature abandonment of resources, and uncertainty regarding future gas supplies.

- The uncertainty related to the future costs of environmental compliance has increased the financial risk associated with exploration and production operations. 
2-14 


\section{program goals and strategies}

\section{technology}

Goal: Develop cost-effective natural gas supply technologies that overcome the unique exploration, production, and processing barriers associated with natural gas-bearing geologic formations of varying characteristics.

\section{Strategies:}

- In coordination with other stakeholders, characterize the geological barriers to development associated with various natural gas deposits such as low permeability formations, fractured reservoirs, deep reservoirs, heterogeneous and compartmentalized reservoirs, Devonian shales, coalbed methane under enhanced nitrogen injection, low quality gas, and gas hydrates.

- Identify technology needed to remove technological barriers to increasing long-term natural gas supply from the diverse set of geologic deposits.

- In partnership with industry, develop and implement RD\&D programs for advanced technology development to enhance production and reduce the costs of exploration, production, and processing of natural gas.

- Sponsor demonstrations of new and existing technology in diverse geologic settings and disseminate information on performance and costs to potential users.

- Develop advanced technologies that can take raw, variable quality natural gas, and economically upgrade it to the quality level required for the range of market uses of natural gas and/or convert it to the fuel form required by market uses of transportation and other hydrocarbon liquids. 


\section{market}

Goal: Foster confidence that the marketplace can ensure cost-effective supplies of natural gas.

\section{Strategies:}

- Develop methodologies to convert remote and otherwise unmarketable gas to economically transportable and marketable form and to determine its realistic potential contribution to longterm natural gas supply.

- Promote awareness by industry, particularly independent producers, of the advantages of advanced technology.

- Identify the barriers to the use of advanced technology and support industry efforts that promote adoption of advanced technology.

- Identify and quantify the sources of potential additional natural gas production resulting from application of advanced technologies.

\section{policy/regulatory}

Goal: Promote reform of Federal and State policies and regulations that impede the economically efficient development of natural gas resources.

\section{Strategies:}

- Evaluate development options for areas currently under moratoria and assess their potential contribution to long-term natural gas supply.

- Identify and quantify the sources of potential additional natural gas production resulting from economic and tax policy incentives.

- Explore opportunities for enhanced interaction and coordination with other Federal agencies and States to ensure long-term natural gas supply at reasonable prices, e.g., promote policies for increased use of natural gas as a valid option in a portfolio of fuel options.

- Identify Federal, State, and local government regulations that place an undue burden on the natural gas exploration, production, and processing sectors of the industry; and design and implement activities for improved coordination of regulatory decisionmaking. 
- Invest in a natural gas RD\&D program that fosters the rate of technology advancement needed to ensure longterm natural gas supply.

- Explore options for employing more creative cost-sharing arrangements in order to stimulate a greater number of industry-government partnerships focusing on long-term supply.

\section{environment}

Goal: Promote cooperation with Federal, State, and local regulatory bodies to reduce the negative impact of environmental regulations on long-term natural gas supply; promote risk-based regulatory decisionmaking; and improve environmental performance of exploration and production operations.

\section{Strategies:}

- Support environmental regulations that are risk-based, address specific problems, and do not impede natural gas production.
- Support RD\&D activities to improve environmental performance of exploration and production operations; and promote initiatives to reduce environmental regulatory compliance costs.

- Conduct and support outreach activities to improve public perception of exploration, production, and processing operations and their impact on the environment. 
2-18 


\section{performance indicators}

\section{technology}

Near-Term (2000)

- Complete reservoir characterization of the first-tier priority resource base (representing one-third of the resource base): the low permeability formations located in the western United States, a portion of the coalbed methane resource, a portion of the low quality gas, deep gas, and fractured reservoirs.

- Demonstrate, through cost-shared projects with industry, technologies developed to overcome the production and cost barriers identified for low permeability formations in the western basins, and unmineable coals.

- Measure an increase in domestic natural gas production by an incremental 1.5 to 2.0 Tcf/year.

- Develop low-volume, physical conversion technology to reduce costs of remote wellhead gas conversion to transportable liquefied natural gas by 25-50 percent.

- Complete proof-of-concept development of oxyhydrochlorination conversion of methane for liquid fuel and petrochemical import replacement.

Mid-Term (2005)

- Complete reservoir characterization of the second-tier priority resource base (representing one-third of the resource base): remaining low permeability formations, remaining coalbed methane formations under nitrogen enhancement, remaining low quality gas, and a portion of the Devonian shales.

- Demonstration, through cost-shared projects with industry, of technologies developed to overcome the production and cost barriers identified for remaining low permeability formations, remaining coalbed methane formations, remaining low quality gas, and a portion of the Devonian shales.

- Develop and establish feasibility of advanced, two-step syngas conversion of natural gas to diesel and related transportation fuels at costs similar to oil-derived fuels.

- Complete development of a suite of advanced gas upgrading processes available, at small-to-large scale, to allow an average 50 percent reduction in present day costs of treating the one-third of domestic natural gas that is sub-quality. 


\section{Long-Term (after 2010)}

- Complete reservoir characterization of the third-tier priority resource base (representing the remaining one-third of the resource base): remaining Devonian shales and gas hydrates.

- Demonstration, through cost-shared projects with industry, of technologies developed to overcome the production and cost barriers identified for the remaining Devonian shales, deep gas, fractured reservoirs, and gas hydrates.

- Measure an increase in domestic natural gas production by an incremental $5 \mathrm{Tct} /$ year.

\section{market}

Near-Term (2000)

- Measure a reduction in drilling and equipment costs by 1 percent per year.

- Measure a reduction in the number of dry holes by 5 percent.

- Measure an industry deployment rate of 80 percent for all DOE-sponsored products (e.g., drill bits, information systems, models).

- Complete a quantitative assessment of the potential additional natural gas production resulting from the application of advanced technology.

\section{Mid-Term (2005)}

- Measure a reduction in the costs of processing typical low quality gas by 50 percent.

- Observe the construction of a series of 50,000 barrels per day $/ 300$ million cubic feet per day gas-to-transportation liquid plants to obtain national potential of one million barrels per day of oil-competitive fuel within six to seven years.

- Measure an increase in the industry deployment of all DOE-sponsored products to 90 percent.

- Measure a reduction in energy imports. Long-Term (after 2010)

- Measure the deployment of DOEsponsored technologies as adding seven years of natural gas supply to domestic proved reserves.

- Measure the replacement of 25 percent of oil-based diesel transportation fuels with gas-derived alternative fuels.

\section{policy/regulatory}

\section{Near-Term (2000)}

- Complete a quantitative assessment of the impact of E\&P moratoria on long-term supply of natural gas.

- Promote necessary increased funding to support an RD\&D program for advanced technology. 
- Measure stakeholder response to more efficient mechanisms to disseminate information on advanced technology.

- Complete a quantitative assessment of the additional potential natural gas production resulting from economic and/or tax policy incentives.

- Complete assessment of options and outstanding issues for utilization of producible Alaska North Slope natural gas no longer required for secondary North Slope oil production.

- Complete assessment of the feasibility of expanded natural gas (and oil) production in remote offshore U.S. locations without feasible pipeline gathering system capacity.

\section{Mid-Term (2005)}

- Promote continued funding of a viable RD\&D program for advanced technology.

\section{environment}

Near-Term (2000)

- Continued compilation and transfer of scientific information and support for State and national policymaking concerning natural gas supply.

- Implementation of risk-based regulations by Federal and State agencies.

- Demonstration, through cost-shared projects with industry, of environmental compliance technology which reduces environmental compliance costs by 10 percent.

- Transfer, through cost-shared demonstration, awareness to the underground coal mining industry three or more alternative approaches to capture and utilize methane releases from coal presently uneconomic to recover and utilize.

Mid-Term (2005)

- Demonstration, through cost-shared projects with industry, of environmental compliance technology, which reduces environmental compliance costs by an additional 10 percent.

\section{Long-Term (2010)}

- Assess degree of statutory requirement for energy impact assessments to be performed before enactment of any new legislation which applies to energy production. 



\section{program overview}

\section{program activities summary}

The Natural Gas Supply program includes three main areas: (1) Exploration and Production (formerly known as Office of Fossil Energy's Resources and Extraction program); (2) Natural Gas Processing (includes Fossil Energy's Low Quality Natural Gas Upgrading program and Gas-to-Liquids program); and, (3) Fundamental Research. This combination of programs represents the full spectrum of activities included in the natural gas supply system.

The Exploration and Production program includes three product lines and two initiatives: (1) Drilling, Completion, and Stimulation Product Line; (2) Low Permeability Formations Product Line; (3) Resources and Reserves Product Line; the Advanced Computational Technology Initiative; and the Climate Change Action Plan: Coal Mine Methane.

The Drilling, Completion, and Stimulation product line focuses on reducing costs and improving process efficiencies of reaching and recovering natural gas from various types of geological formations in an environmentally benign manner. It also addresses the barriers associated with the cost-effective completion and stimulation of natural gas wells in various types of geologic settings. The current program includes projects related to increasing the penetration rate during drilling operations, improvements in measurement-while-drilling, and improving the design of hydraulic fractures.

The Low Permeability Formations product line will develop and demonstrate economical and efficient tools and techniques for recovering natural gas from geologically complex low permeability reservoirs containing large volumes of natural gas. Included are projects involving the intersection of naturally occurring fracture systems, and the demonstration of cost-effective production technology in low permeability formations.

The Resources and Reserves product line focuses on identifying, characterizing, quantifying and modeling the most attractive targets upon which to focus the exploration and production research effort. This is a diverse effort involving projects related to databases and modeling, improving recovery from mature fields, basin analysis, and technology transier.

The Advanced Computational Technology Initiative unleashes the advanced computational power of the National Laboratories for use in processing natural gas and oil data associated with all aspects of exploration, production, and processing research. The first round of projects includes activities related to improved reservoir modeling, improved process modeling (i.e., drilling, fracturing), and improved three-dimensional seismic data imaging. 
The Climate Change Action Plan: Coal Mine Methane activities focus on the capture of methane associated with the mining of coal. This effort involves demonstration of current technology to improve the penetration rate of this technology into the coal mining industry.

The Natural Gas Processing program is comprised of two areas: (1) Low Quality Natural Gas Upgrading; and (2) Gas-toLiquids.

\section{The Low Quality Natural Gas Upgrading} product line focuses on developing techniques for removing large quantities of impurities from raw natural gas, thus upgrading the quality of the gas to a more pure stream of methane and without poisonous concentrations of hydrogen sulfide.

The Gas-to-Liquids product line focuses on developing economical techniques to convert natural gas streams into more easily transportable liquid forms of hydrocarbon fuel, either liquefied natural gas or chemically stable liquid hydrocarbons as alternatives to oil-based transportation fuels.

The Fundamental Research program focuses on the origin, migration, and entrapment of natural gas for improved understanding of the geologic factors controlling and limiting the availability of natural gas. This program resides within the Office of Energy Research.

\section{changes from previous plan}

Natural gas supply related activities in the FY 1994 Natural Gas Strategic Plan and Multi-Year Program Crosscut Plan were included under the Resource and Extraction Area. These activities are now grouped under the Natural Gas Supply Technology Panel. The same sub-areas were retained in the current plan, but reorganized to reflect the "product line" approach the Department has adopted. The Advanced Computational Technology Initiative program has been added to the Natural Gas Supply program. The Natural Gas Processing program was created and includes the Low Quality Gas Upgrading and the Gas-to-Liquids product lines. The Gas-to-Liquids activity was previously in the Utilization Area of the FY 1994 Plan.

A key improvement in Office of Fossil Energy's supply program is the utilization of the key product lines by which to organize the program and improve interaction with stakeholders. A total of seven supply system-related product lines are being pursued within the Office of Fossil Energy. The following five product lines are described in the Natural Gas Supply Plan: (1) Drilling, Completion, and Stimulation; (2) Low Permeability Formations; (3) Resources and Reserves; (4) Low Quality Natural Gas Upgrading; and (5) Gas-to-Liquids. The remaining two product lines: (1) Delivery, and (2) Storage are discussed in the "Delivery and Storage" Program Plan. 


\section{FY 1994-1996 budget summary}

(Dollars in Million)

\begin{tabular}{|l|c|c|c|}
\hline DOE Office & $\begin{array}{c}\text { FY 1994 } \\
\text { Actual }\end{array}$ & $\begin{array}{c}\text { FY 1995 } \\
\text { Approps. }\end{array}$ & $\begin{array}{c}\text { FY 1996 } \\
\text { Request }\end{array}$ \\
\hline Fossil Energy & 19.6 & 25.0 & 37.9 \\
\hline Energy Research & 7.0 & 7.2 & 7.4 \\
\hline Total DOE & 26.6 & 32.2 & 45.3 \\
\hline
\end{tabular}

'Appropriation 



\section{references}

1 National Petroleum Council, The Potential for Natural Gas in the United States, Executive Summary, December 1992, Figure 3, page 8.

2 Energy Information Administration, Supplement of the Annual Energy Outlook 1995, February 1995, Table 34, page 61.

3 National Petroleum Council, The Potential for Natural Gas in the United States, Executive Summary, December 1992, Table 1, page 5.

4 Energy Information Administration, U.S. Crude Oil, Natural Gas, and Natural Gas Liquids Reserves, 1993 Annual Report, October 1994.

5 Energy Information Administration, Annual Energy Outlook 1995, Table A13, page 89.

6 National Petroleum Council, Research, Development, and Demonstration Needs of the Oil and Gas Industry, Draft Report, 1995.

7 Interstate Oil and Gas Compact Commission, Technology Transfer to U.S. Oil Producers: A Policy Tool to Sustain or Increase Domestic Production. A Report of the Project on Oil and Gas Technology Transfer, January 1990. 



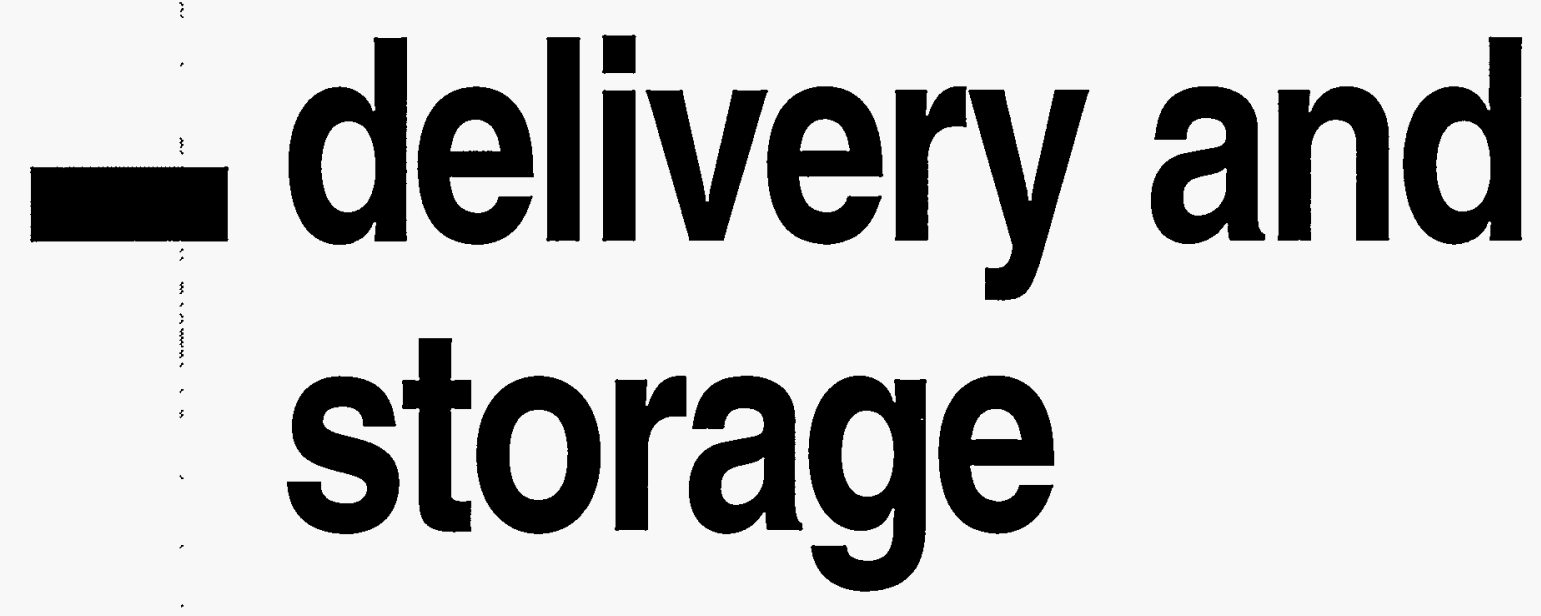



Page No.

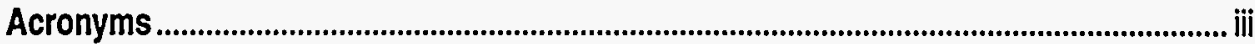

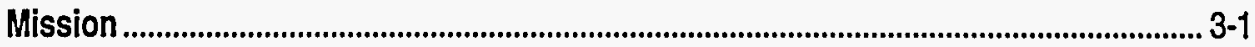

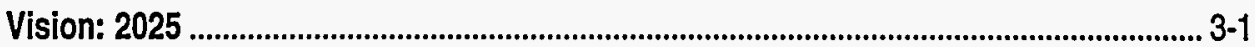

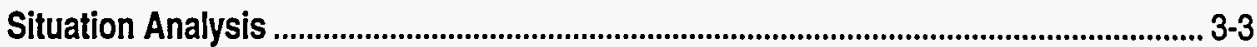

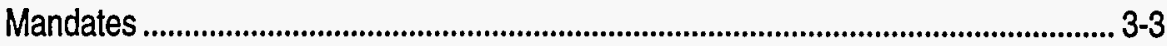

Program Relationships ................................................................................................ 3-3

Current Situation .................................................................................................... $3-5$

DOE Position ..................................................................................................................... $3-7$

Stakeholder Considerations ................................................................................... 3.8

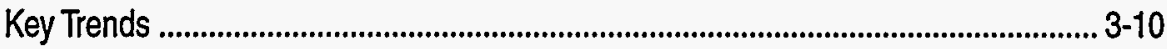

Key Planning Assumptions ................................................................................ $3-11$

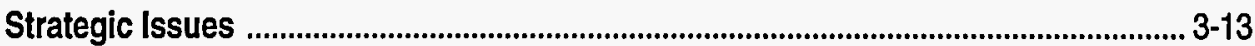

Program Goals and Strategies............................................................................................ 3-15

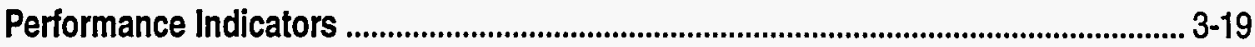

Program Overview ............................................................................................

Program Activities Summary .............................................................................. 3-21

Changes from Previous Plan ................................................................................... 3-21

FY 1994-1996 Budget Summary ........................................................................ 3-22 


\begin{tabular}{|c|c|}
\hline AGA & American Gas Association \\
\hline Bcf & Billion Cubic Feet \\
\hline CAAA & Clean Air Act Amendments of 1990 \\
\hline CCAP & Climate Change Action Plan \\
\hline CRADA & Cooperative Research and Development Agreement \\
\hline DOE & Department of Energy \\
\hline EIA & Energy Information Administration \\
\hline EIAGIS-NG & Energy Information Administration Geographical Information System - Natural Gas \\
\hline ENRIMS & Energy and Natural Gas Resource Information Management System \\
\hline EPA & U.S. Environmental Protection Agency \\
\hline EPACT & Energy Pọlicy Act of 1992 \\
\hline FERC & Federal Energy Regulatory Commission \\
\hline FY & Fiscal Year \\
\hline GRI & Gas Research Institute \\
\hline INGAA & Interstate Natural Gas Association of America \\
\hline LDC & Local Distribution Company \\
\hline METC & Morgantown Energy Technology Center \\
\hline O\&M & Operating and Maintenance \\
\hline OPS & Office of Pipeline Safety \\
\hline PC & Personal Computer \\
\hline P.L. & Public Law \\
\hline $\mathrm{RD} \& \mathrm{D}$ & Research, Development, and Demonstration \\
\hline Tcf & Trillion Cubic Feet \\
\hline UPRM & Uniform Production Reporting Model \\
\hline
\end{tabular}





\section{mission}

DOE's Delivery and Storage program, in partnership with industry and stakeholders, undertakes activities to develop and deploy advanced technologies and promotes policies that increase the efficiency and ensure the continued safety and reliability of the U.S. natural gas storage, transmission, and distribution system.

\section{vision: 2025}

The Nation's natural gas storage, transmission, and distribution system is cost-effective, safe, and reliable in delivering natural gas for the benefit of residential, commercial, industrial, transportation sectors, and electric utility customers. Natural gas is the fuel of choice for new and emerging markets in the United States. Significant industry investment in the delivery and storage infrastructure has fostered increased supply regions and market opportunities. Real-time metering of pipeline flows and increased deliverability from storage have enhanced operational flexibility of the gas delivery system. High deliverability storage near new market areas and hubs with access to multiple pipelines has increased overall system deliverability and has been accomplished in response to market demand. America's advanced natural gas delivery technologies are purchased and used worldwide. 


\section{wituation analysis}

\section{mandates}

The Delivery and Storage program will comply with all applicable Federal, State, and local laws and regulations, and Administration and DOE regulations and policies. Requirements of immediate relevance include the Clean Air Act Amendments of 1990 (CAAA), the Energy Policy Act (EPACT), the Climate Change Action Plan (CCAP), congressional funding requirements, and the Administration's natural gas policy directives, in particular The Domestic Natural Gas and Oil Initiative.

\section{program relationships}

\section{department of energy}

Within DOE, the principal responsibility for research in natural gas delivery and storage lies within the Office of Fossil Energy, which works in cooperation with other Departmental program offices to accomplish the program objectives (e.g., Offices of Energy Efficiency and Renewable Energy, and Policy, and the Energy Information Administration). The Delivery and Storage program reflects the need to assure that natural gas continues to be delivered reliably and costeffectively in a deregulated environment. To that end, consideration of policy and regulatory issues of the DOE Delivery and Storage program has been expanded to address the need to develop and deploy advanced technologies that support the cost-effective, safe, and reliable operation of the natural gas delivery infrastructure. The program is implemented by Morgantown Energy Technology Center (METC). In addition, the Energy Information Administration (EIA) is developing an accurate, reliable, and timely information system for natural gas storage data. This information system will provide the capability to evaluate domestic storage capacity and deliverability on a site-specific basis. The system is incorporated into EIA's larger Geographical Information System. The comprehensive scope of the industry-related data in this system provides a powerful PC-based tool to support a broad range of analyses of storage issues.

Another program goal is to develop a national deliverability capacity model. This model will provide the capability to evaluate seasonal and peak-day supply and consumption and other issues on a regional basis. This PC-based tool will support analysis of current natural gas industry capability, as well as investigate the impact of projected changes in gas supply and demand patterns on the capability of the delivery system to meet domestic requirements. 
Planned research will build on the

deliverability and storage findings and recommendations of the National Petroleum Council report, The Potential for Natural Gas in the United States (1992); the Federal Energy Regulatory Commission (FERC)/DOE study, Natural Gas Deliverability Task Force Report (1992); The Domestic Natural Gas and Oil Initiative (1993); and the Energy Information Administration reports, Natural Gas Productive Capacity for the Lower 48 States (1994); and The Value of Underground Storage in Today's Natural Gas Industry (March 1995).

\section{industry associations}

The natural gas industry, through the Gas Research Institute (GRI), supports a comprehensive technology-based program in supply, distribution, and transmission, and end-use research, development, and demonstration (RD\&D). On May 20, 1994, DOE and GRI signed a Memorandum of Understanding, which established coordination of the two organizations' natural gas RD\&D efforts. This agreement will bring together DOE and GRI program personnel who will review the objectives of their respective natural gas programs and identify opportunities for joint efforts. DOE's goal is to support the delivery of natural gas through its Delivery and Storage program by advancing and deploying technologies and methodologies in a manner that responds to major industry needs and is complementary to the natural gas industry's research program.
DOE also is working with the American Gas Association (AGA) and the Interstate Natural Gas Association of America (INGAA) to identify areas of common need and priority. In addition, DOE will work closely with industry organizations and the vendor community supporting the cost-effective, timely, safe, and reliable operation of the natural gas storage, transmission, and distribution system.

\section{other federal agencies}

The Federal Energy Regulatory

Commission, an independent agency, regulates the construction and operation of interstate natural gas facilities and the rates for interstate natural gas service. FERC Order No. 636, issued in April 1992, has transformed the interstate natural gas pipeline industry by requiring the separation of pipeline companies' sales, transportation, and storage services to allow customers to contract only for the mix of services they need. It allows the development of a secondary market for released pipeline capacity, encourages the development of market hubs, and requires electronic bulletin boards to provide on-line access to information regarding available capacity. This has opened the underground storage market to more participants and created a demand for a variety of storage services.

Department of Transportation, Office of Pipeline Safety (OPS): OPS' mission is to protect the people and environment of the United States through a comprehensive 
pipeline safety program that includes effective risk management, thorough pipeline compliance, high quality training, and a strong, balanced Federal/State partnership. OPS establishes and makes sure industry complies with standards that protect the public and the environment in gas and hazardous liquid pipeline transportation. OPS has a safety prevention program that encourages States to assert safety regulatory jurisdiction over all or some intrastate pipelines. The Federal government is authorized to pay half of States' pipeline safety program costs. Funding for OPS is generated from user fees collected from transmission pipelines under the Pipeline Safety Reauthorization Act of 1994. The fiscal year 1995 budget for OPS has increased partly in response to pipeline incidents in New Jersey and Texas in 1994. OPS is conducting research and development on prevention of mechanical and collateral damage to transmission pipelines.

\section{state and local governments}

State Public Utility Commissions (PUCs) have jurisdiction over the retail sale and local distribution of natural gas and over the local distribution companies (LDCs) that provide those services. DOE works, on a collaborative basis, with PUCs that are reviewing their regulations and policies to increase competition in retail natural gas markets.

\section{current situation}

Underground storage is a vital part of the natural gas industry. The ability to store natural gas ensures supply reliability during periods of heavy demand by supplementing pipeline capacity and serving as backup supply in case of an interruption in wellhead production.

The delivery and storage component of the natural gas industry has made significant investments in new and expanded facilities as well as changes in the way the facilities are used. The interstate transportation system is continuing to expand both its pipeline and storage capacity. Increased natural gas consumption in 1994 was supported by a substantial expansion of the transmission and storage system during the past few years. As of the beginning of 1995, the transmission system is estimated to have the capability to deliver 25 trillion cubic feet (Tcf) of gas on an annual basis and 124 billion cubic feet (Bcf) on a peak-day basis.

Between 1991 and 1994, capacity on the interstate natural gas pipeline system increased by an estimated 12 percent, or 10 billion cubic feet per day. The total cost of new pipeline development and expansion implemented during the period is estimated to be about $\$ 6.5$ billion. The major portion of this outlay occurred in the Western and Northeast regions of the Nation where natural gas markets were expanding. In May 1995, there were more than 40 new or expansion pipeline projects of varying sizes under construction or 
before the FERC or State agencies for consideration and review. These projects, if developed, would bring an additional 5.6 billion cubic feet per day ( $\mathrm{Bct} / \mathrm{d}$ ) of pipeline capacity to current capabilities by January 1998. This would represent an increase of 7 percent from pipeline capacity in place on January 1995. In addition, in 1994, underground storage capacity was at approximately $8 \mathrm{Tcf}$ in 375 storage sites around the country. Of this, 3.7 Tcf was available to support daily operations to natural gas markets during peak periods. Since 1992, daily deliverability from underground storage has increased by about 6 percent to almost $68 \mathrm{Bcf} / \mathrm{d}$.

The operational flexibility of the pipeline network has been enhanced by the expanded access to underground storage under FERC Order No. 636. Increased access to underground storage, combined with the storage deliverability additions planned within the next few years, will allow more extensive use of the interstate pipeline system. Under FERC Order No. 636, most interstate storage became open access, with up to 90 percent of it now available to natural gas transportation customers.

While the implementation of FERC Order No. 636 is a major milestone in the restructuring of the underground storage industry, the marketplace itself has already induced significant change. Most notable has been the dramatic increase in planned and recently developed storage capacity. Much of this new storage is salt cavern or other highdeliverability type storage where natural gas can be injected and withdrawn on a continuing basis throughout the year to balance daily or monthly demands. If all proposed projects that had been announced by mid-1994 were completed as planned, working natural gas capacity would increase by almost 13 percent by 1999 from the level in 1993. Deliverability from storage would increase by 31 percent.

However, concerns about market uncertainties, surplus of capacity in some areas, and the potential inability to recover construction costs have led to a slowdown in mainline capacity expansion. In 1994, only three small expansion projects were completed and several major proposed projects were either downsized, canceled, postponed, or withdrawn from the FERC approval process. Moreover, the backlog of expansions for the period, $9.7 \mathrm{Bct} / \mathrm{d}$, is 18 percent lower than the $11.8 \mathrm{Bct} / \mathrm{d}$ (47 projects) of mainline capacity expansion booked for the 1991-1994 period. In fact, in southern California and some other localities, there is temporary excess in interstate pipeline capacity.

What has been emerging is a trend toward capacity expansion to support increases in deliverability into new local market areas and to offer new services to potential natural gas customers. For instance, proposed capacity expansions into the Northeast region currently amount to $0.7 \mathrm{Bct} / \mathrm{d}, 58$ percent below the 1.7 $\mathrm{Bcf} / \mathrm{d}$ completed during the previous 4 years 
(1991-1994). Most of the planned expansions for the region represent expansions to deliverability (0.8 Bct/d) within the regional pipeline network, as pipeline companies are improving services and expanding markets within the region.

Under Order No. 636, FERC's requirements allow shippers to resell unneeded firm capacity. Development of a secondary market for pipeline capacity may reduce the need for new pipeline capacity. Reselling of capacity should enable shippers to use the existing grid more efficiently, thus decreasing the need to build new facilities.

The rupture of a natural gas transmission line in New Jersey on March 23, 1994 drew aftention to potential safety issues relating to the population encroachment on the transmission and distribution infrastructure. In addition, the flooding of an oil pipeline in Texas, in the summer of 1994 has increased the government review of pipeline safety. These incidents prompted an increase in public awareness and congressional funding for pipeline safety. The industry expenditures in pipeline safety for transmission and distribution gas pipelines is approximately $\$ 800$ million per year. The Pipeline Safety Reauthorization Act of 1994 increased transmission pipeline and hazardous liquid pipeline user fees for 1995 from $\$ 47$ to $\$ 97$ per transmission mile for pipeline safety and risk assessment. The increased user assessment fee would generate approximately $\$ 40$ million to the Department of Transportation, Office of Pipeline Safety.

\section{DOE position}

Development of technologies leading to costeffective expansion of storage capacity, and enhanced deliverability, is an integral element of DOE's Delivery and Storage program, aimed at increasing end-user confidence in natural gas as a reliable energy source. This program is driven by the anticipated 4 Tcf increase in natural gas demand by 2010 , resulting in a need for a supporting natural gas storage infrastructure to meet the anticipated increase in capacity and delivery, and by the significant industry restructuring in response to FERC Order No. 636. Under this Order, FERC's aim was to make the industry more competitive. The increased competition placed further reliance on accurate and timely production reporting data and information, on the value and use of storage facilities, and on real-time gas flow monitoring and energy measurement technologies to maximize the use of pipeline capacity while operating efficiently.

DOE's Delivery and Storage program responds to industry needs critical to assuring continued efficient and reliable gas industry performance by targeting development of technology leading to: (1) improvements in underground storage deliverability, (2) more efficient reservoir management, (3) development of advanced storage concepts and alternative storage methods, (4) deployment of the Uniform Production Reporting Model (UPRM) guidelines to ensure accurate, timely, and reliable gas production data and deliverability information, and to lower producers' 
administrative costs, (5) development of improved and expanded real-time pipeline gas flow metering and energy measurement technologies for improving the reliability of natural gas deliveries, (6) development of improved instrumentation and gas flow metering and monitoring technologies for storage operations, and (7) the development of a national deliverability capacity and storage model with a geographical information system.

\section{DOE recognizes that mechanical and} collateral damage can occur to natural gas transmission and distribution pipelines due to population encroachment and aging of the pipeline system. In addition, DOE supports Federal/State and industry partnerships to improve gas system deliverability, reduce leakage, and to assure pipeline safety over the lifetime of the transmission system. Improved pipeline gas flow metering and energy measurement technology RD\&D is necessary to ensure continued efficient and reliable natural gas industry performance. DOE's Delivery and Storage program supports new and improved technologies to enhance the reliability of pipeline operations and ensure accurate energy deliveries.

\section{stakeholder considerations}

- Producers: Producers will benefit from an efficient storage and delivery system by being able to sell natural gas yearround with summer volumes going into storage rather than having to shut-in production wells. Producers benefit from the accurate measurement of gas volumes that they ship by pipelines to end users.

- Pipeline Companies: Pipelines are seeking improved deliverability and storage utilization. Pipelines benefit from increased efficiency, resulting from automated controls and measurement systems that lower operational costs and increase their rate-of-return on investments. Pipelines support regulatory reform that encourages companies to increase storage capacity and can operate more efficiently with better knowledge of the market demand. Pipeline companies are trying to optimize operation and maintenance expenditures. Pipelines will use storage for supply balancing, emergency backup, and no-notice services to maintain system reliability.

- Local Distribution Companies: These companies are concerned with increasing the reliability, flexibility, and deliverability of natural gas services. They benefit from improved operational control that results 
from accurate and real-time measuring and monitoring of gas in their pipeline systems and accurate forecasts of market use.

- Natural Gas Storage Operators: Increased deliverability is the key issue for storage operators. This group is facing increased and more complex responsibilities for managing storage operations under the FERC Order No. 636 , which requires that storage be unbundled from other pipeline services. They will want financial rewards to be commensurate with the increased risks.

- Natural Gas Marketers: Marketers are seeking improved information and data on pipeline capacity and availability on a real-time basis, and will benefit from an electronic natural gas information network system that increases their ability to provide efficient natural gas services.

- Major Natural Gas Consumers: Electric utilities, independent power producers, and industrial natural gas consumers want reliable supply and price stability to help facilitate long-term planning and to preclude supply interruptions. In addition, they desire economically efficient technologies for natural gas-fueled electricity generation.

- Environmental Groups: These groups are pressing for reduced emissions. Increased utilization of natural gas in the electricity generation sector is responsive to the CAAA.
- Research and Educational Community: These organizations seek to expand Federal funding for their RD\&D efforts and to participate with DOE in the demonstration of technologies.

- Equipment Vendors: These companies seek to develop and market equipment that will reduce costs and improve efficiency for pipeline operations and storage facilities.

- Investment Community: Lenders and investors are concerned with reducing the risks of financing natural gas-related technologies. Capital is needed to construct the required storage and distribution systems along with the continued development of new technologies.

- Congress: Industry-driven cooperative cost-shared RD\&D programs with GRI and other non-Federal sources receive more congressional support than government-only funded research. Cost sharing of 40 to 50 percent is sought. Congress is concerned about reliability of natural gas to consumers.

- Federal, State, and Local Regulatory Agencies: Regulators are developing policies to increase competition for natural gas transportation, storage, and distribution services. 
- Natural Gas Consumers: The consuming public is seeking more and better choices with respect to natural gas service.

\section{key trends}

\section{technology}

- The natural gas storage industry currently spends over $\$ 100$ million annually to maintain deliverability from existing storage facilities.

- The natural gas industry is mainly developing high deliverability storage projects (salt domes) that offer the flexibility to respond quickly to changes in market conditions.

- Cooperation is increasing between the Federal government and industry, as well as other stakeholders, on commercialization and deployment efforts in deliverability enhancement technologies for natural gas storage fields.

- Significant demand is emerging for advanced technology based products, methods, and services in response to environmental, operational, and efficiency considerations.
- Advanced techniques and information technology are becoming critical to the operation of the natural gas delivery and storage system in an increasingly competitive market.

- Applications of computing and information technologies are increasing throughout DOE natural gas programs. These information systems are resulting in reduced risks and improved decisionmaking concerning development of natural gas storage reservoirs.

- Access to Internet information systems is becoming a requirement as States develop production reporting system models for natural gas producers to report their production data to States' conservation, tax, and royalty agencies.

- The natural gas industry is working aggressively to sustain the efficiency, reliability, and safety of the existing delivery and storage infrastructure, while expanding capacity to meet new demand and accommodate shifts in sources of supply.

\section{market}

- New market centers, or hubs, with access to multiple pipelines, are being developed throughout the U.S. supply regions, enhancing pipeline service and transportation flexibility. 
- The restructuring of the natural gas industry is driving the need for real-time management of the natural gas system and; therefore, the need for state-of-theart information management systems.

- Increased competition in natural gas markets has changed supply and consumption patterns, giving consumers greater flexibility in choosing the type of natural gas service which best meets their needs.

- Advances in electronic information transfer and computing technology are playing an increasingly larger role in tracking natural gas flows.

- Increased competition in U.S. electricity markets will increase the need for improved natural gas system deliverability.

- A worldwide market is opening for advanced natural gas supply, transmission, storage, and enduse technologies.

\section{policy/regulatory}

- The Federal government is continuing to promote increased competition in natural gas transportation markets.

- There is a growing emphasis on environmental considerations at the Federal, State, and local levels, and environmental risk perceptions are increasingly driving regulatory policy regarding natural gas delivery and storage systems.

- Natural gas-related initiatives of EPACT (P. L. 103-486, Section 2014) are being implemented to improve development of advanced natural gas storage and deliverability technologies.

\section{environment}

- Environmental issues, policies, and programs continue to increase the demand for natural gas use, which increase the government requirements for a comprehensive pipeline safety program.

- Public tolerance for risk related to environmental and public safety issues continues to be minimal with reference to siting of natural gas storage facilities near new market areas.

\section{key planning assumptions}

\section{technology}

- Improved reservoir management practices will lead to higher working natural gas storage ratios.

- Integrated application of advanced operating and maintenance (O\&M) technologies will continue to improve the safety, and reliable and cost-effective delivery of natural gas. 
- Advanced metering and information will be necessary elements of cost-effective pipeline system operation in increasingly competitive natural gas markets.

- New storage concepts will contribute to needed natural gas use patterns in power generation.

\section{market}

- Increased demand for natural gas will result in a corresponding increased demand for delivery and storage services.

- To serve the increasing demand and address the regional shift in sources of supply, new storage and delivery facilities will need to be constructed.

- Regional flow patterns will shift, reflecting the decline of the Southwest as a supply source and the increasing importance of the Rocky Mountain region and Canada.

- Recent declining wellhead deliverability will cause natural gas storage to become a more critical issue. If wellhead deliverability continues to decline, storage will be used to meet an even larger portion of the seasonal demand.
- There will be a continuing need for the construction of new facilities to adapt to changing supply and market patterns.

- The reliability and marketability of natural gas will increase because of the development of new and expansion of existing market hubs and the increasing ways marketers can get natural gas to the end user.

\section{policy/regulatory}

- The environmental constraints associated with siting, permitting, construction, and use of various natural gas delivery and storage facilities are likely to be more stringent.

- Federal, State, and local environmental regulations over delivery and storage service will expand in depth and scope.

\section{environment}

- Concerns regarding the environmental effects of natural gas transportation and storage systems will increase.

- Leakage within the system will remain an issue with EPA and climate change researchers because of the greenhouse gas contributions. 


\section{strategic issues}

\section{technology}

- Collective natural gas RD\&D resources and activities of industry and government currently are inadequate to develop the supply, delivery and storage, and end-use technologies required to fully capture the total benefits offered by natural gas.

- Technology advances to enhance the reliability of the natural gas delivery and storage system through efficient, timely, accurate information, uniform State production reporting guidelines, and the construction and utilization of new natural gas storage facilities are necessary for natural gas to realize its full potential.

- The natural gas industry continues to focus on short-term return-on-investment, which inhibits necessary investment in new storage and delivery technologies.

- Conventional underground formations amenable to storage applications are limited in certain market areas.

\section{market}

- In the increasingly diverse and competitive natural gas industry, adequate and timely natural gas supply and demand information currently is not widely available to support wellinformed natural gas market decisions.

- Current peak-day demand, pipeline bottlenecks, and limited deliverability to certain markets could lead to delivery problems during severe cold spells near the end of the storage withdrawal season.

\section{policy/regulatory}

- The construction of natural gas delivery and storage facilities remains subject to comprehensive and lengthy approval processes at the State and Federal levels.

- Concerns over rate treatment for new natural gas transportation facilities may delay the construction of needed new facilities.

\section{environment}

- Uncertainty over future environmental regulations impedes the market acceptance of new technologies. 
3-14 


\section{program goals and strategies}

\section{technology}

Goal: Promote the development of advanced natural gas delivery and storage technologies.

\section{Strategies:}

- Develop technologies and methodologies that contribute to cost-effective pipeline system operation and maintenance as a means of enhancing consumer confidence in the reliability of natural gas and potentially lowering transportation costs. (Near-Term)

- Identify and evaluate the feasibility of alternative technologies suitable for natural gas storage and delivery applications. (Near-Term)

- Develop timely, accurate, and reliable reservoir and gas storage deliverability information systems to support the natural gas markets. (Near-Term)

- Increase the utilization of high performance computing and information technologies to fully integrate the natural gas system. (Near-Term)

- Develop long-term and short-term natural gas demand models for use in forecasting, planning, and managing the delivery system operations. (Near-Term)

- Investigate field development strategies for new and expanding natural gas storage fields. Assess potential geologic formations for their development as storage reservoirs in these market areas. (Near-Term)

- Develop and demonstrate new and improved cost-effective technologies for reservoir management and control of gas migration/leakage from storage fields. (Near-Term)

- Demonstrate new storage and delivery technologies to optimize the economics of natural gas storage and delivery. (Mid-Term)

- Participate in natural gas storage/end-user demonstration tests to establish the reliability of alternative storage methods. (Mid-Term)

- Develop technologies that address the constraints associated with natural gas storage in aquifers thereby facilitating the construction of new aquifer storage capacity. (Mid-Term) 


\section{market}

Goal: Promote the adoption and use of technologies necessary to achieve the economically efficient delivery and storage of natural gas; and increase public confidence in the long-term availability, reliability, and safety of the natural gas delivery and storage infrastructure.

\section{Strategies:}

- Identify strategic market areas for new and growing natural gas use, projected natural gas demand, and the storage capacity/delivery required for these areas. (Near-Term)

- Evaluate alternative natural gas storage methods that have the potential to meet the expected demand increase from major natural gas consumers. (Near-Term)

- Define and improve system aspects of natural gas storage/delivery technologies and participate in natural gas storage/ end-use demonstration tests to establish the reliability of peak-load deliverability. (Near-Term)

- Support development of better communication systems between Federal, State, and local decisionmakers and industry to provide timely information. (Near-Term)
- Assist the natural gas industry in identifying, developing, and disseminating information concerning natural gas delivery and storage to support operation in a market-based environment. (Near-Term)

\section{policy/regulatory}

Goal: Promote Federal and State policies which will further the efficient development of the U.S. natural gas delivery and storage system.

\section{Strategies:}

- Articulate and promote a national perspective to Federal, State, and local regulatory bodies affecting natural gas delivery and storage.

- Work with State and local decisionmakers to ensure that Federal, State, and local policies on delivery and storage are complementary, serving both the Nation, the States, and localities.

- Work with FERC to remove barriers to environmentally sound construction of additional pipeline and storage facilities, and encourage increased access to existing facilities.

- Assist in the implementation of policy changes to remove impediments to natural gas delivery and storage.

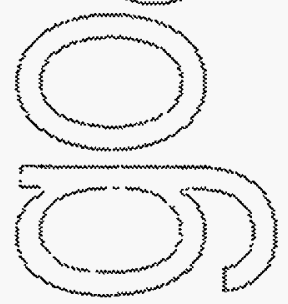




\section{environment}

Goal: Maximize the environmental benefits of natural gas delivery and storage systems.

\section{Strategies:}

- Assist the natural gas industry in the development of natural gas delivery and storage systems that enhance environmental quality.
- Assist the natural gas industry in developing and disseminating information on the environmental benefits and impacts of natural gas delivery and storage.

- Assure that the environmental benefits of gas delivery and storage are not impeded by regulatory or other policies. 
3-18 


\section{performance indicators}

\section{asset management}

- Development of a seasonal short-term natural gas usage forecast modeling system enabling local distribution companies, marketers, and gas transmission companies to better predict the short-term demand for natural gas. (Near-Term)

- Development of cost/benefit models enabling the analysis of various environmental control strategies on the natural gas delivery system and overall impact of these strategies on environmental quality, energy security, and the U.S. economy. (Near-Term)

- Completion of the National Deliverability Capacity Model and dissemination of analytical capability. (Near-Term)

- Completion of the design and demonstration of a national electronic natural gas deliverability information network system. (Near-Term)

- Linkage of producing States through an online system to improve natural gas reliability and monitor gas supplies from "wellhead to burnertip" through a national electronic natural gas deliverability information network. (Mid-Term)

\section{delivery}

- Development and deployment of advanced remote sensing technologies, such as laser remote sensing, to improve maintenance and inspection decision support systems, facilitate pipeline mapping, enable assessment of cathodic protection leakage, and enhance leak detection and location. (Near-Term)

- Development of sensors enabling the real-time measurement of natural gas flow, energy content, and quality. (Near-Term)

- Continued improvement in the safety and reliability of the existing plastic natural gas distribution piping network through development of technologies necessary for enhancing inspection and maintenance decision support systems. (Mid-Term)

- Development and deployment of advanced technologies for repairing and/or replacing plastic mains and services under live conditions to ensure uninterrupted natural gas delivery. (Mid-Term)

- Improvements in the deliverability of natural gas through the development of rapid, reliable, and economical tools for quick natural gas service installations. (Mid-Term) 


\section{storage}

- Demonstration and dissemination of the EIAGIS-NG (formerly called ENRIMS) underground storage application capability for evaluating changes in the development and use of storage, and the interconnections among storage areas and pipelines. (Near-Term)

- Demonstration of natural gas as a reliable fuel source by using storage reservoirs to supply natural gas during peak-demand periods for the power generation market through actual tests and demonstrations. (Near-Term)
- Improved reservoir management techniques to mitigate the effects of gas migration from storage reservoirs, demonstrated in research and verification tests. (Mid-Term)

- Development of alternative storage methods for areas where conventional underground storage is not feasible, and conduct of feasibility and verification tests evaluated for these methods. (Mid-Term)

- Development of improved technologies for enhancing natural gas storage field deliverability. (Mid-Term)
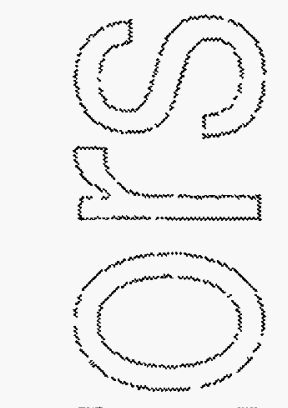

$5 . . .5$

$\cdots$
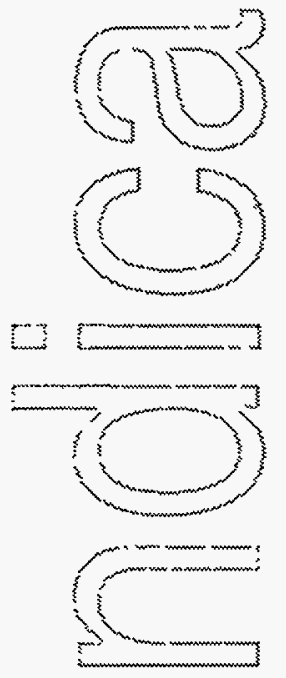

1..

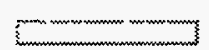




\section{program overview}

\section{program activities summary}

The Delivery and Storage program is partitioned into the Delivery (transmission and distribution) and Storage project areas. The Delivery program projects are: Implementation of the Uniform Production Reporting Model guidelines at the State level; Development of Improved Real-Time Pipeline Flow Measurement Technology; and the Development of the National Deliverability Capacity Model. The Storage projects are: Storage Well Instrumentation for Monitoring Gas Flow and Gas Quality Metering Technologies; EIAGIS-NG Underground Storage Applications; Match Gas Storage to End-User Requirements; Storage Well Revitalization and Improvement: Storage Reservoir Management; and METC In-House Gas Storage Research. Planned research activities for FY 1995 form the foundation for DOE's RD\&D program for FY 1996 and the outyears.

DOE's research program is designed to be cost shared with industry, with industry's share increasing as research efforts move towards the demonstration phase. During fiscal year (FY) 1991-1994, DOE/METC has maintained a cooperative research effort with major natural gas utilities using geologic modeling and reservoir simulation to address aspects of deliverability, reservoir management, and storage optimization. Numerical simulators have been updated to incorporate surface facilities modeling, thus increasing the systems approach capability used to address storage and delivery technology issues. In FY 1995, METC will continue a series of cooperative research and development agreements (CRADAs) with natural gas utilities to develop a methodology to address the major issues of storage field deliverability and reservoir management.

\section{changes from previous plan}

Overall, the Delivery and Storage program elements remain substantially the same as those of the previous version. The Delivery program continues to be proposed for FY 1996, although no funding was appropriated by Congress for FY 1995. In terms of contents, the Situation Analysis discussion has been revised to reflect its relationship to The Domestic Natural Gas and Oil Initiative; Key Trends, Key Assumptions, Strategic Issues, and Goals and Strategies are presented within the framework of technology, market, policy/regulatory, and environment; and Goals and Strategies have been revised to reflect industry input and are, to the extent possible, also presented in a framework compatible with the Planning Assumptions and Strategic Issues. 


\section{FY 1994-1996 budget summary}

(Dollars in Million)

\begin{tabular}{|l|c|c|c|}
\hline DOE Office & $\begin{array}{c}\text { FY 1994 } \\
\text { Actual }\end{array}$ & $\begin{array}{c}\text { FY 1995 } \\
\text { Approp* }\end{array}$ & $\begin{array}{c}\text { FY 1996 } \\
\text { Request }\end{array}$ \\
\hline Fossil Energy & 1.0 & 1.1 & 3.1 \\
\hline Total DOE & 1.0 & 1.1 & 3.1 \\
\hline
\end{tabular}

'Appropriation

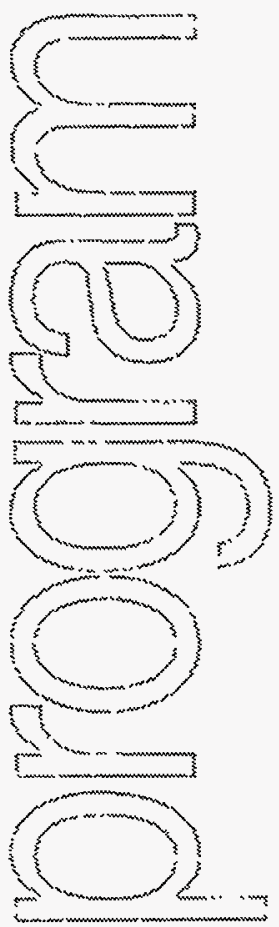




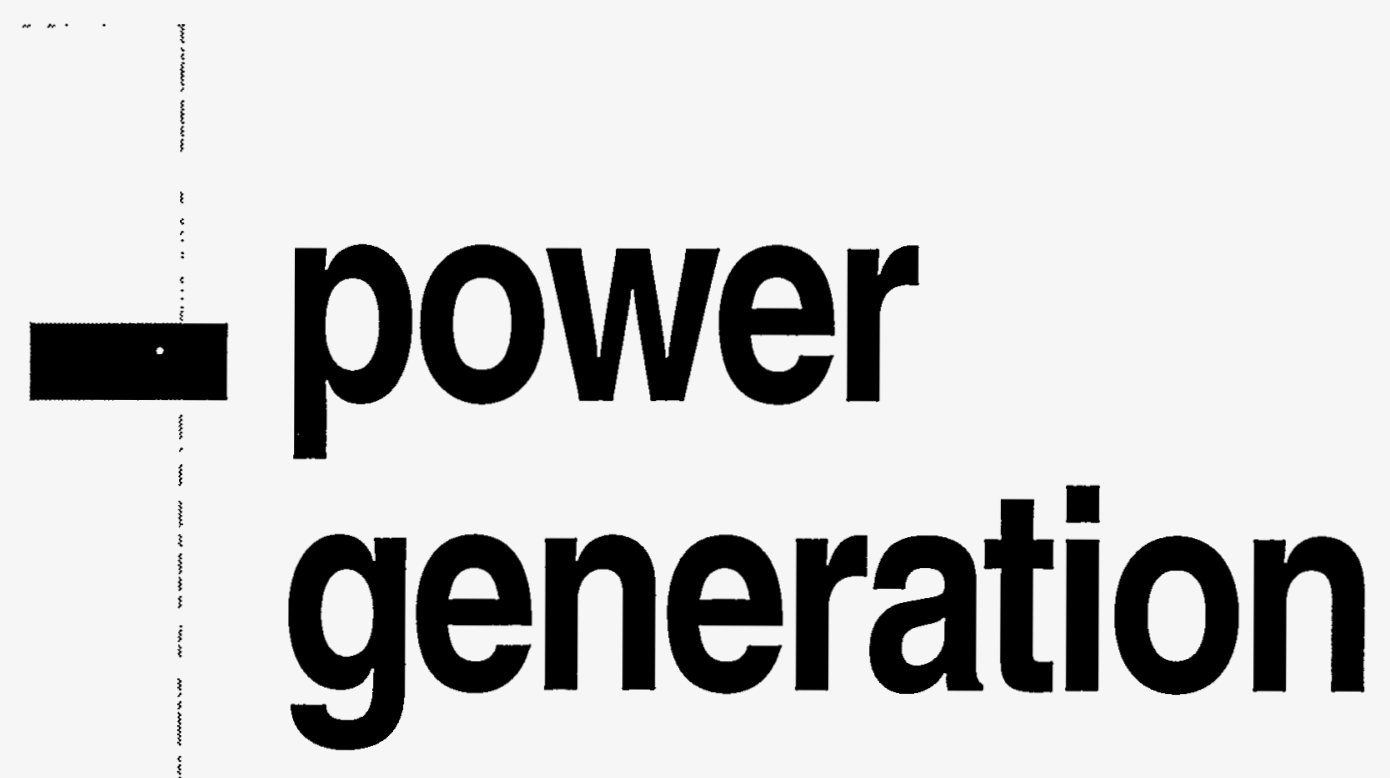


19.

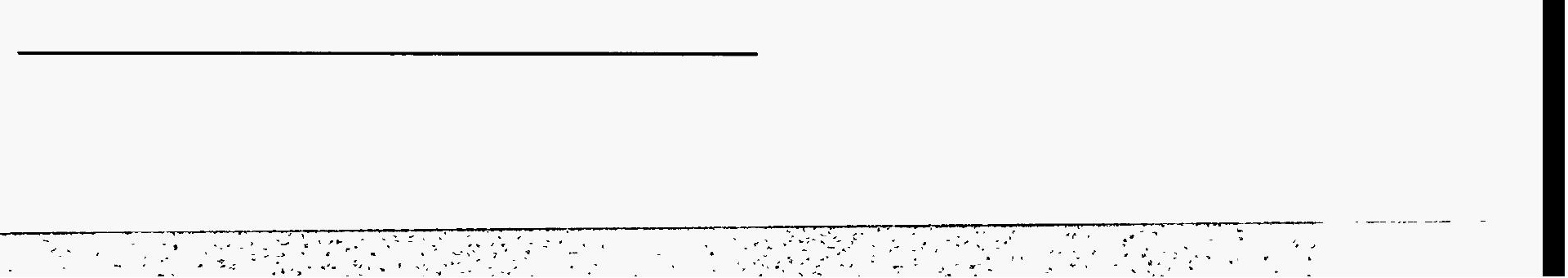


Page No.

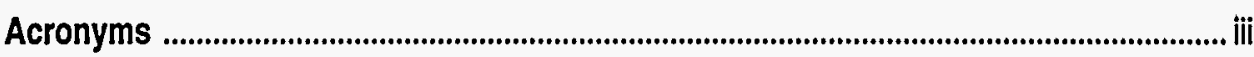

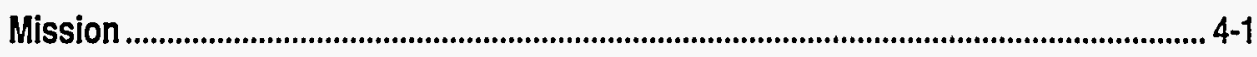

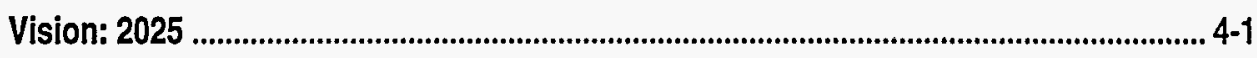

Situation Analysis ........................................................................................................... 4-3

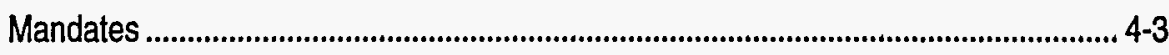

Program Relationships ................................................................................. 4-3

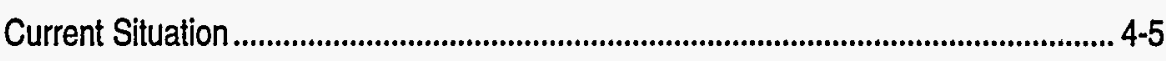

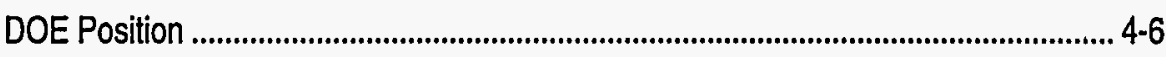

Stakeholder Considerations ............................................................................ 4-6

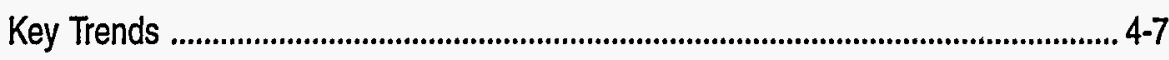

Key Planning Assumptions ..................................................................................... 4-8

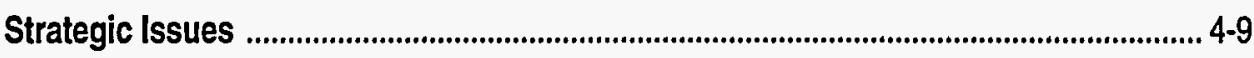

Program Goals and Strategies ....................................................................................... 4-11

Performance Indicators ................................................................................................. 4-15

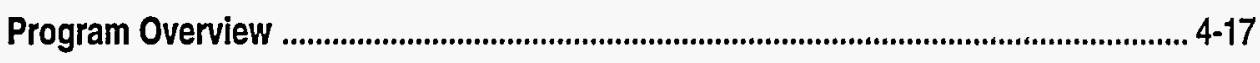

Program Activities Summary ........................................................................................ 4-17

Changes from Previous Plan ........................................................................... 4-20

FY 1994-1996 Budget Summary ..................................................................., 4-20 


\section{acronyms}

\begin{tabular}{ll} 
AMFA & Alternative Motor Fuels Act of 1988 \\
ARPA & Advanced Research Projects Agency \\
ATS & Advanced Turbine Systems \\
Btu & British Thermal Unit \\
CAAA & Clean Air Act Amendments of 1990 \\
CAGT & Collaborative Advanced Gas Turbines \\
CO & Carbon Monoxide \\
CO & Carbon Dioxide \\
DOC & Department of Commerce \\
DOD & Department of Defense \\
DOE & Department of Energy \\
DOT & Department of Transportation \\
DSM & Demand-Side Management \\
EPA & U.S. Environmental Protection Agency \\
EPACT & Energy Policy Act of 1992 \\
EPRI & Electric Power Research Institute \\
FERC & Federal Energy Regulatory Commission \\
FY & Fiscal Year \\
GRI & Gas Research Institute \\
GW & Gigawatt \\
IRP & Integrated Resource Planning \\
LDC & Local Distribution Company \\
NARUC & National Association of Regulatory Utility Commissioners \\
NASA & National Aeronautics and Space Administration \\
NOPR & Notice of Proposed Rulemaking \\
NO & Nitrogen Oxides \\
PAFC & Phosphoric Acid Fuel Cell \\
PUC & Public Utility Commission \\
RD\&D & Research, Development, and Demonstration \\
SO & Sulfur Dioxide \\
Tct & Trillion Cubic Feet \\
\hline
\end{tabular}





\section{mission}

DOE's Power Generation program, in partnership with industry and stakeholders, undertakes activities and promotes policies to foster development and deployment of new, improved power generation systems to enhance the use of natural gas in that sector.

\section{vision: 2025}

Natural gas is a major source of clean, efficient, reliable and affordable electricity being provided to customers across the United States. Federal and State actions allow customers to choose from among several power generation providers equipped with advanced power systems to serve a variety of on-site, distributed and central power markets ranging from homes, businesses, industries, public buildings and facilities. U.S. natural gas-based power technologies are well established worldwide and are supplying clean natural gas-based electricity to other countries. 



\section{situation analysis}

\section{mandates}

DOE's Power Generation program will comply with all applicable Federal, State, and local laws and regulations, and Administration and DOE policies. It will be conducted within the guidance of Federal requirements, e.g., National Environmental Policy Act (NEPA), Energy Policy Act of 1992 (EPACT), Clean Air Act Amendments of 1990 (CAAA), Alternative Motor Fuels Act of 1988 (AMFA), and Federal and DOE energy acquisition regulations.

\section{program relationships}

\section{department of energy}

DOE's Power Generation program is conducted through the Offices of Fossil Energy, Energy Efficiency and Renewable Energy, Energy Research, and Policy. DOE's work on gas-based power generation systems is coordinated with the efforts of external stakeholders and customers, both private and public. Work is planned to complement other efforts and in many cases will be cooperatively supported by non-DOE funding organizations. These include the Gas Research Institute (GRI) and the Electric Power Research Institute (EPRI) for projects such as fuel cells and advanced gas turbines. The work generally is cost shared by private sector participants that expect to benefit from the program results. GRI conducts a comprehensive program addressing gas utilization issues in all sectors, including electric power, industrial, transportation, and residential and commercial.

The Power Generation program will be coordinated with GRl's program to incorporate GRI/ industry participation and expertise, and to ensure that activities are cooperative and complementary. EPRI conducts a diverse program addressing issues of interest to member electric utilities. Like GRI, it enjoys effective industry participation in its program development and planning. EPRI's expertise covers a wide range of utility issues and technologies.

In the regulated power generation market, EPRI, GRI, and DOE have encouraged the use of the Integrated Resource Planning (IRP) and Demand-Side Management (DSM) concepts in utility planning. Also, DOE has provided advice and positions to States regarding the electric utility market restructuring and direct access issues. 


\section{other federal agencies}

Federal authorities, other than DOE, conduct programs that contribute to or otherwise affect the development of gas-based power generation technologies. For example, the National Aeronautics and Space Administration (NASA), Department of Defense (DOD), Department of Transportation (DOT), and Department of Commerce (DOC) conduct gas turbine and other natural gas research, development, and demonstration (RD\&D) activities. Gas turbine technology, initially developed for aircraft engines, can significantly enhance the performance of stationary gas turbine systems in electric power applications. The Joint Services' integrated high performance turbine engine program and the Department of the Navy's intercooled recuperated turbine program will develop technology with such an application. Additionally, the Advanced Research Projects Agency (ARPA) also funds fuel cell development for dual-use applications in coordination with DOE's Office of Fossil Energy.

The Federal Energy Regulatory Commission (FERC) has jurisdiction over: (1) the wholesale sale and transmission of electricity in interstate commerce, (2) the wholesale sale and transportation of natural gas in interstate commerce, and (3) the construction and operation of interstate natural gas transportation facilities.

\section{state and local}

\section{governments}

Many State and local governments implement policies, programs, and regulations that directly affect gas utilization and gas-based power generation. These programs range from support for technology development (such as advanced systems for power generation) to regulations on air emissions. State public utility commissions (PUCs) have jurisdiction over retail sale and distribution of electricity. Several PUCs require or encourage natural gas utilities to develop DSM programs. DSM is part of the IRP or leastcost planning concept, which was initially devised for the electric utility industry to minimize or reduce utilities' load profile during peak demand.

The IRP process is used by PUCs and utilities to balance supply and demand options in a utility's investment plans to meet future energy needs with maximum efficiency at the lowest cost. Twenty-three States are at various stages of IRP development. Initial implementation and/or mandating has begun in several States. Compared to the electric utility industry, gas utility IRP/DSM practices are at early stages of development; however, progress has been made in applying these practices in some States (e.g., Georgia). 


\section{current situation}

As of year-end 1994, electric utility generating capacity in the U.S. totalled about 703 gigawatts (GW), of which gas-fired capability was $134 \mathrm{GW}$ or 19 percent. Coal and petroleum accounted for $310 \mathrm{GW}$ (43 percent) and $70 \mathrm{GW}$ (10 percent), respectively. Generating capacity based on other fuels was $99 \mathrm{GW}$ for nuclear (14 percent), $78 \mathrm{GW}$ for renewables (11 percent), and $21 \mathrm{GW}$ for hydroelectric (3 percent). Total capacity included $3.8 \mathrm{GW}$ of newly added capability. Of this, $3 \mathrm{GW}$, or 79 percent, was gas-fired capability. In 1994, natural gas-powered plants provided 10 percent, or 21 billion kilowatt hours, of total U.S. electricity production, compared with 9 percent in 1993. Increasingly, natural gas also has been the major fuel used by nonutility electricity generators. In 1993, natural gas fueled more than half of all nonutility electric generation, and natural gas consumption in this sector has been climbing steadily for several years [2.7 trillion cubic feet (Tcf) in 1993 and 3 Tcf in 1994].

Recent technology improvements have increased the prospect of expanded and more efficient natural gas utilization in the power generation sector. Among them have been the development of advanced turbines, fuel cells, and cofiring and reburn technologies. In addition, on-site users with gas-fired cogeneration plants and distributed power producers, both with the capability to switch fuel, have increased the use of natural gas.
With respect to power generation, EPACT contains several natural gas-related provisions that will have significant impacts on gas use. Included is the opportunity for increased use of natural gas in electricity generation by nonutility power producers.

On March 29, 1995, the FERC issued a Notice Of Proposed Rulemaking (NOPR) to "promote wholesale competition through open access, non-discriminatory transmissions services..." and for "recovery of stranded costs by public utilities and transmitting utilities." It is anticipated that increased competition in wholesale electricity markets may in the short-term slow the pace of new natural gas-fired generation units, due to excess capacity and price competition; however, it is also anticipated that in the mid-and long-term, natural gas will gain market share due to its environmental benefits and superior efficiency.

Provisions of the CAAA, requiring compliance with emissions limits, offer significant opportunities for increased natural gas use with respect to power generation. Emission rates from natural gas use are the lowest of any fossil fuel, whether the emission is sulfur dioxide $\left(\mathrm{SO}_{2}\right)$, nitrogen oxides $\left(\mathrm{NO}_{x}\right)$, carbon monoxide (CO), or particulates. However, challenges remain for increased gas use if emission standards become more stringent on $\mathrm{NO}_{x}$ and the greenhouse gas emissions of $\mathrm{CO}_{2}$ and methane. 


\section{DOE position}

DOE promotes removing or overcoming regulatory, market, and technical obstacles to expanded power generation markets for natural gas. In particular, DOE supports the implementation of programs to address EPACT requirements. EPACT has several provisions to encourage the commercialization of natural gas-based power generation technologies such as high efficiency, low emission gas turbines and fuel cells.

With regards to proposed State regulatory changes and the institutional restructuring of the electricity market in pursuit of economic efficiency and economic benefits, DOE has emphasized to the States the importance of ensuring the achievement of other important electricity-related public policy objectives. These include environmental protection, fuel and technology diversity, incentives for investments in research, development, and demonstration of new technologies, equitable allocation of risks and benefits between stakeholders and customers, Integrated Resource Planning, and DemandSide Management.

\section{stakeholder considerations}

A number of groups with significant interest in the success of the gas-based power generation programs include the following:

Natural Gas Producers, Interstate Natural Gas Pipeline Companies, Local Distribution Companies: These companies will benefit from an increased market provided by efficient, cost-effective end-use technologies with low emissions, especially for on-site and distributed power generation.

Independent Power Producers, Electric Utility Companies, Natural Gas Utility Companies: These companies will also benefit from the development of viable, cost-competitive, advanced natural gas power systems.

Environmental Organizations: These groups will continue to press for reduced environmental impacts. Development of advanced gas-based power generation technologies and systems will enhance their view of natural gas as a fuel of choice.

Federal, State, and Local Regulatory Agencies and Governments: DOE's Power Generation program will provide these organizations with an increased collection of attractive options for environmental improvement while serving the electricity needs of the consumers. For example, the development of advanced high efficiency, environmentally benign gas turbine and fuel cell systems will provide reduced power plant emissions. 
However, on the State level, in various regions there may be regulations that favor indigenous fuel use. In addition, movements towards reduced regulations in the utility industry in some States could pose obstacles for introducing new, advanced natural gas technologies in the power generation market.

Research and Educational Community: These organizations will seek expanded cooperation with the Federal government in RD\&D efforts and to participate with DOE in improving and transferring advanced gasbased power generation technology to the private sector.

Equipment Vendors: End-use manufacturers are seeking to develop and sell more efficient, lower emission gas-based power generation equipment and systems to maintain their competitiveness in the U.S. and overseas markets.

Congress: A credible, relevant gas-based power generation program will remain a major component of a viable overall natural gas program. Cost-shared, industry-driven RD\&D programs coordinated with those of GRI and other non-Federal sources will result in a rational and balanced program supported by Congress.

Public: The public desires that the government role in power generation be prudently selected and effectively administered without undue influence of special interests.

\section{Electricity Customers/Consumers: Changes} in technology, legislation, and regulation have introduced competition into the supply of electricity and initiated an era of major change in the structure of industry. Increased competition in the electricity industry will benefit customers and the natural gas industry. Customers will be seeking market-based prices for electricity and electricity marketing efforts will intensify as competition increases.

\section{key trends}

\section{technology}

- Partnership between the public and private sectors is resulting in new and improved generating technologies, which benefit from increased natural gas use and have superior environmental attributes.

\section{market}

- The demand for electric power in the U.S. continues to increase, although partially offset by increased end-use efficiency measures.

- The emergence of distributed power generation as an electricity supply strategy is encouraging power production at a scale well suited to natural gas utilization.

\section{policy/regulatory}

- The electricity industry is becoming increasingly competitive as a result of legislative and regulatory actions at Federal and State levels. 


\section{environment}

- Increasingly stringent environmental regulations have been encouraging increased natural gas use for power generation.

\section{key planning assumptions}

\section{technology}

- Highly efficient natural gas-based power generation technologies will promote greater penetration of natural gas into the power generation market.

- Continued development and commercialization of power generation technologies will reduce capital and operating costs, expanding market opportunities for all sectors of the natural gas industry.

\section{market}

- The domestic natural gas resource base is sufficient to meet the projected increase in demand created by the continued development and commercialization of advanced power generation technologies.

- Increases in natural gas demand will be driven primarily by the electric generation and industrial sectors.
- Natural gas will maintain a competitive advantage in power generation markets due to its efficiency and its environmental advantages relative to other fossil fuels.

- Regulatory reform at the State and Federal levels will result in increasingly competitive electricity markets.

\section{policy/regulatory}

- Regulatory reform will continue.

\section{environment}

- Increasing efficiency and lowering emissions of advanced gas-based power generation technologies will increase the economic and environmental benefits of natural gas use.

- Environmental constraints associated with siting, permitting, and construction of power plant facilities likely will be more stringent. The "greenhouse" effect of $\mathrm{CO}_{2}$ and methane emissions will continue to be an environmental concern.

- Implementation of the CAAA and EPACT will encourage increased natural gas use in the power market sector. 


\section{strategic issues}

\section{technology}

- The combination of government and private sector resources is inadequate to properly support the RD\&D and commercialization of advanced natural gas utilization technologies.

- Commercialization of more advanced gas-based power generation technologies (such as fuel cells) is facing difficulty because of the high capital requirements for a new technology and the absence of aggressive demonstration programs.

- If U.S. industry continues to focus primarily on short-term return on investment, investment in and deployment of advanced power generation technologies could be limited.

\section{market}

- The higher price of natural gas relative to coal makes it difficult to expand its presence in the base-load market for utility applications. Dispatching on cost based on current rate structures has largely limited gas-powered systems to peak and intermediate load applications except in some regions where gas combined cycle systems are being used for base-load generation.

- Power producers are concerned about price stability and supply reliability of natural gas over the long-term. Some electric utilities express concern about committing to investments that require a 20 -year natural gas supply.

\section{policy/regulatory}

- The cumulative impact of compliance costs associated with Federal, State, and local regulations (including environmental) could constrain future utilization of natural gas.

- Current State ratemaking regulations regarding the purchasing of new but more costly advanced technologies (including demonstration systems) are not conducive for utilities to assume attendant risks without prospects of return on investments for such risks.

- Existing State regulations in certain regions favoring indigenous fuel use (such as coal) can impede the deployment of advanced gas power systems in those States.

\section{environment}

- Emission limits could severely hamper gas-based power generation systems as a pollution mitigation approach. 
4-10 


\section{program goals and strategies}

In support of achieving the power generation vision for gas, the overall program goal is to expand the clean, efficient and economic use of natural gas in the utility-scale, distributed, and on-site power market sectors through: (1) the successful development, demonstration, and commercialization of advanced power generation systems that can meet existing and new demands; and (2) the reduction of market hurdles and removal of regulatory barriers to the deployment of new, advanced gas-based power generation technologies into the power generation market. The following are specific goals and strategies:

\section{technology}

Goal: Complete programs leading to the commercialization by the private sector of highefficiency, environmentally superior, cost-competitive gas turbine systems, and molten carbonate and solid oxide fuel cells for utility-scale, distributed, and on-site power applications.

\section{Strategies:}

- Conduct a cost-shared RD\&D program to achieve prototype demonstration of advanced gas turbine systems for both distributed and central power utility-scale service.

- Support development, integration, and scaleup of molten carbonate and solid oxide fuel cell power plants through the demonstration plant stage (with increasing levels of cost sharing).

- Develop ceramic technology for high temperature gas turbines.

- Conduct commercialization activities that target commercial entry of these advanced turbine systems by the year 2000 .

- Coordinate with the Department of Defense on supporting market penetration of near-term power plants ready for commercial offering (e.g., phosphoric acid fuel cells). 


\section{market}

Goal: Complete RD\&D for

commercialization of utility-scale

advanced gas turbine systems and

significant market penetration of molten

carbonate and solid oxide fuel cell power

plants for on-site cogeneration as well as

new and repowering central power

plant applications.

\section{Strategies:}

- Continue RD\&D program to enhance performance of advanced gas turbine systems after the first market introduction (e.g., improved materials modifications, cost reduction, enlarged configurations); and support expanded applications at competitive costs (e.g., use of industrial turbines for distributed power systems).

- In partnership with industry, support expanded market penetration and focus on cost-shared development and demonstration of system integration, scaleup, simplification, improvement, and cost reduction advances aimed at offering marketable, fuel-flexible molten carbonate and solid oxide fuel cell power plants.
- Promote and support activities to overcome regulatory and market barriers to the introduction of natural gas use (e.g., advanced turbine systems, cofiring and reburning) into State and regional base-load power markets.

- Conduct domestic and export market analyses to enhance understanding of customer concerns and the U.S. indusiry competitiveness.

\section{policy/regulatory}

Goal: Foster market opportunities and overcome hurdles for commercialization of advanced gas-based power generation technologies both domestically and globally.

Strategies:

- Work with States and other stakeholders, including participation in the National Association of Regulatory Utility Commissioners (NARUC) on matters such as increased competition, industry restructuring, ratemaking, environmental regulations, and integrated resource planning.

- Participate in the State rulemaking process to encourage the enactment of State regulations which allow for introduction of new technologies into the primary power market. 
- Institute regional strategies to impact changes to ratemaking and dispatching on the basis of integrated resource planning.

- Conduct optimization analyses as input to the decisionmaking process with regard to investments, regulations, and market response to changes in the power industry.

\section{environment}

Goal: Achieve consistent and rational emissions standards set by States and EPA to allow U.S.-developed gas-based power generation systems to compete in the power generation market.

\section{Strategies:}

- Support and participate in RD\&D activities to develop technology for meeting environmental standards as part of power generation systems.

- Encourage and promote science-based regulatory decisionmaking by Federal and State regulatory bodies in establishing standards that allow economically and realistically achievable emission levels for specific applications, areas, and regions. 
4-14 


\section{performance indicators}

\section{technology}

- Number of successful demonstrations leading to the commercial offering of highly efficient, cost-competitive advanced gas turbines and fuel cells with low $\mathrm{NO}_{\mathrm{x}}$ emissions.

- Deployment of new gas-based power generation technologies including advanced gas turbines utilizing high temperature ceramics.

\section{market}

- Increase in share of primary power markets supplied by natural gas, achieved through increased commercialization of gas-based power generation technologies.

- Number of market incentives and degree of assistance provided by industry and Federal, State, and local governments to foster market penetration of advanced power systems and products.

\section{policy/regulatory}

- Increasing industry cost-sharing in DOE gas-based power generation RD\&D programs.

- Number of States making effective regulatory changes that provide incentives for the development, introduction, and deployment of advanced power systems into the regulated power market.

\section{environment}

- Number of States and regions in which advanced gas-based power generation systems and cofiring/reburn systems are being dispatched due to environmental considerations. 
4-16 


\section{- program overview}

\section{program activities summary}

The Power Generation program consists of elements supported by the Offices of Fossil Energy, Energy Efficiency and Renewable Energy (Energy Efficiency), Energy Research, and Policy. The primary focus of the programs is to develop advanced high-efficiency, low pollution power generation technologies for increased effective natural gas use; and to overcome technical, market, and regulatory obstacles to their adoption and deployment. The following is a summary of current power generation program activities:

Advanced Turbine Systems (ATS) (Fossil Energy and Energy Efficiency): This program is designed to develop advanced gas turbine systems for electric power production by utilities and nonutility generators. They will be competitive with other technologies for low emissions. Work on the ATS program will be guided by a steering committee composed of representatives of Fossil Energy, Energy Efficiency, GRI, EPRI, and EPA.

Gas Turbines (Energy Efficiency): These programs are modifying existing engines and developing ceramic components for stationary gas turbines. These will achieve considerable fuel savings and reduced emissions in industrial, distributed, and utility-scale applications.

Fuel Cells (Fossil Energy): Fossil Energy manages programs to develop, scaleup, and demonstrate fuel cell technologies. The program is focused on the development of fuel cell technology application to stationary, on-site, and distributed power plants. Fuel cells also have significant potential for direct cogeneration in industrial, commercial, and residential applications. Phosphoric Acid Fuel Cells (PAFCs) are being commercialized by industry primarily for on-site (including cogeneration) power applications. Advanced natural gas-based fuel cells (molten carbonate and solid oxide) are being developed for on-site, industrial, and distributed power applications by the year 2000 . For the longer term, development of larger systems to serve central power plant applications is planned for completion by 2010.

Improved Combustion Control (Fossil Energy): These programs will reduce natural gas combustion emissions to levels now attainable only using post-combustion controls. This technology can be applied to improvements in emissions from Advanced Turbine Systems.

Commercialization/Market Studies (Fossil Energy and Energy Efficiency): These studies would identify hurdles and opportunities (e.g., State, regulatory, market). 


\section{Electric Utility Restructuring Analysis} (Fossil Energy and Energy Efficiency): These studies would qualitatively assess how possible electric industry restructuring scenarios could affect gas-based power generation, and provide analytical groundwork for quantitative analyses of the electric industry restructuring through sensitivity assessments. These analyses and assessments would lead to recommendations for policy options regarding Federal and State regulations, would identify the implications of the electric utility industry restructuring on the natural gas industry, and in conjunction with stakeholders, would identify areas to target for quantitative analysis.

Other: Other programs which are contributory to the power generation program are described below:

\section{IRP Planning Handbook and Demand-Side Management Technology Status Report} (Energy Efficiency): These projects are directed to aid utilities in planning activities for efficient gas use. The handbook, to be prepared for State PUCs and natural gas utility staff, will contain specific information on the characteristics of the natural gas industry. The status report will contain information on the potential efficiency and costs of residential natural gas technologies that are being installed for utility DSM programs.

\section{Heat Engines Program (Fossil Energy):}

Direct coal-fired gas turbines and direct coalfired diesel engines are being developed for electric power, industrial, and transportation applications. This program involves work addressing the combustion of low-Btu gas in gas turbines that are fueled with coal gas, coupled with some work applicable to natural gas.

\section{Advanced Combustion Program}

(Fossil Energy): One of the key elements of this program is the development of indirectly fired (or direct-fired/recuperated) natural gas systems with water or steam injection. These program elements could find direct application in the natural gas program ATS work.

\section{Gas Stream Cleanup Program}

(Fossil Energy): This program is primarily targeted at cleaning hot gas streams in coalfired gasification and combustion systems. However, some results of the program may have application to natural gas systems, while others could be adapted.

\section{Flue Gas Cleanup Program}

(Fossil Energy): This program is concerned with the cleanup of flue gas streams from coal-fired systems. Technologies related to control of $\mathrm{NO}_{x}$ could be applied to natural gas systems.

\section{Materials Programs (Energy Efficiency): These programs will supply basic materials technology that will allow broad-based improvement in various types of gas power generation systems.}


Other Agencies are also performing work which is applicable to the Natural Gas Strategic Plan. This work, described below, is coordinated with DOE to foster synergism between agency programs.

\section{Fuel Cells (Department of Defense/ARPA):}

The Department of Defense initiated a program in fiscal year (FY) 1993 to demonstrate and use commercially produced fuel cell power plants located on military bases. Also in FY 1993, DOD initiated a program to further develop fuel cell power plants for defense applications. This effort is emphasizing the need for durability and operation on logistics diesel and jet fuels. These programs are continuing and close coordination between the two Departments is being maintained to insure that synergistic benefits are realized.

DOE also has coordinated work with industrial consortiums (most notably GRI and EPRI) to promote the development, demonstration, and subsequent commercialization of advanced gas-based power generation technologies. Some of the industry-driven programs are described below.

\section{Collaborative Advanced Gas Turbines}

(EPRI and Industry): The focus of the Collaborative Advanced Gas Turbines (CAGT) program is to utilize the expertise in turbine design and manufacturing in the aerospace industry in the development of gas turbines for power generation. In cooperation with $\mathrm{DOE}, \mathrm{GRI}$, and several airplane engine manufacturers, EPRI is striving to develop modular, high-efficiency advanced gas turbines for cycle use resulting in efficiencies of 60 percent or higher lower heating value.

Fuel Cells (GRI): The focus of the GRI fuel cell program ( $\$ 5.5$ million for FY 1995) is onsite cogeneration and electric utility distributed power generation equipment fueled with natural gas. With the introduction of a 200-kilowatt phosphoric acid fuel cell power plant in 1992, GRl's program emphasis has shifted from the development of phosphoric acid fuel cells to supporting the development of more advanced molten carbonate and solid oxide fuel cell technologies while maintaining some monitoring activity in the performance of phosphoric acid fuel cell units.

Fuel Cells (EPRI): The focus of the EPRI fuel cell program ( $\$ 4.0$ million for FY 1995) is to develop and commercialize eleciric power plants with the highest possible efficiency and least environmental intrusion. With regard to natural gas-fired fuel cells, small modular distributed generators in the 1-10 megawatt size range are being developed with the expectation that, as capital costs are reduced, these fuel cell systems can be adapted to central power generation applications. 


\section{changes from previous plan}

Power generation related RD\&D activities were previously included in the Utilization Area of the FY 1994 Natural Gas Strategic Plan and Multi-Year Program Crosscut Plan. These activities are combined in the FY 1995 Plan under the Power Generation Technology Panel.

\section{FY 1994-1996 budget summary}

(Dollars in Million)

\begin{tabular}{|l|c|c|c|}
\hline DOE Office & $\begin{array}{c}\text { FY 1994 } \\
\text { Actual }\end{array}$ & $\begin{array}{c}\text { FY 1995 } \\
\text { Approp. }\end{array}$ & $\begin{array}{c}\text { FY 1996 } \\
\text { Request }\end{array}$ \\
\hline Fossil Energy & 71.8 & 87.3 & 99.4 \\
\hline Energy Efficiency & 18.3 & 21.4 & 26.3 \\
\hline Total DOE & 90.1 & 108.7 & 125.7 \\
\hline
\end{tabular}

${ }^{1}$ Appropriation

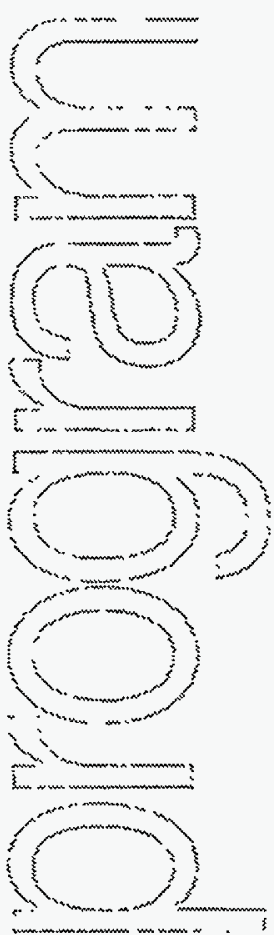




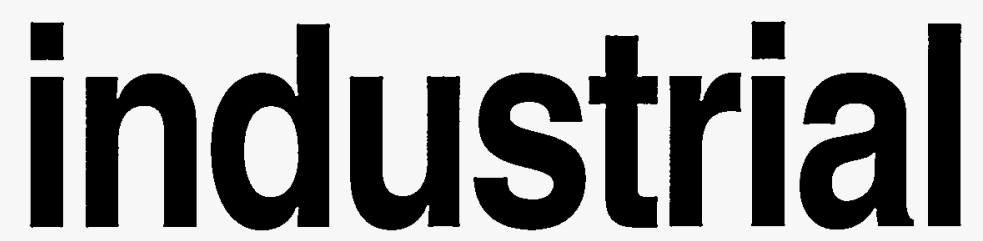




\section{contents}

Page No.

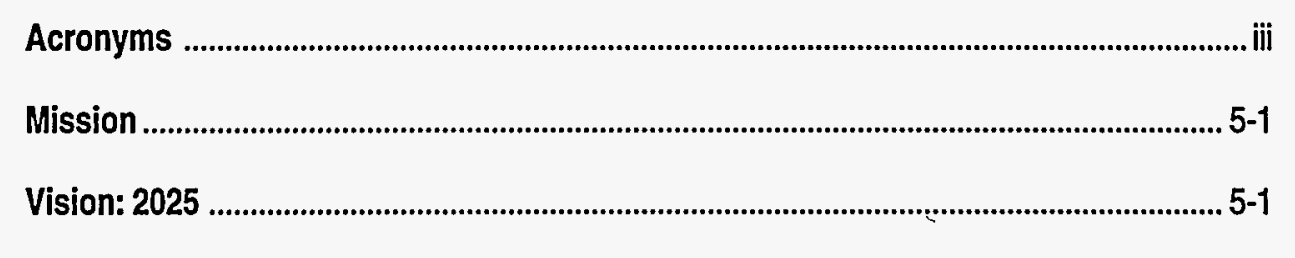

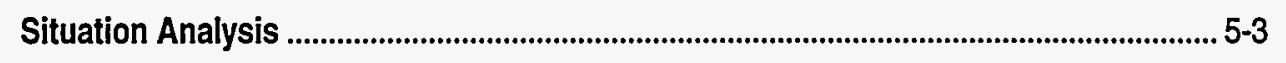

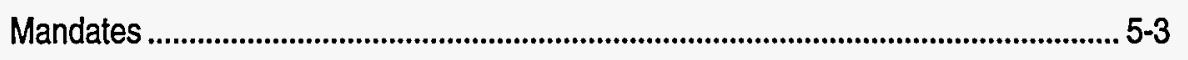

Program Relationships ................................................................................................. 5-3

Current Situation ............................................................................................... 5-4

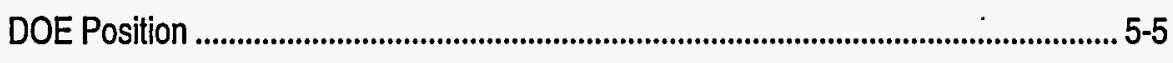

Stakeholder Considerations .............................................................................. 5-5

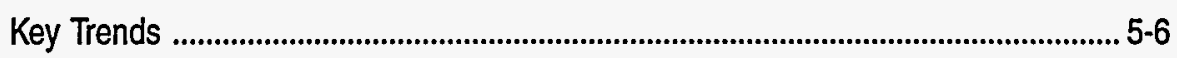

Key Planning Assumptions .................................................................................. 5-8

Strategic Issues .................................................................................................... 5-11

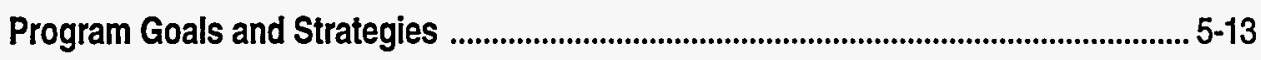

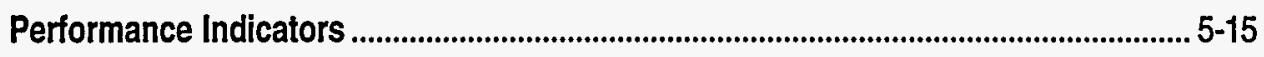

Program Overview .............................................................................................. 5-17

Program Activities Summary ............................................................................... 5-17

FY 1994-1996 Budget Summary ......................................................................... 5-22

Industrial 
ii 
Btu British Thermal Unit

CAAA Clean Air Act Amendments of 1990

co Carbon Monoxide

$\mathrm{CO}_{2} \quad$ Carbon Dioxide

DOD Department of Defense

DOE Department of Energy

DOT Department of Transportation

EPRI Electric Power Research Institute

GRI Gas Research Institute

GTI Gas Technology Information

$\mathrm{H}_{2} \mathrm{~S} \quad$ Hydrogen Sulfide

ICGTI International Center for Gas Technology Information

IEA International Energy Agency

LDC Local Distribution Company

NASA National Aeronautics and Space Administration

NUG Nonutility Generator

$\mathrm{NH}_{3} \quad$ Ammonia

$\mathrm{NO}_{\mathrm{x}} \quad$ Nitrogen Oxides

OIT Office of Industrial Technologies

P.L. Public Law

RD\&D Research, Development, and Demonstration

ppm Parts Per Million

SIC Standard Industrial Classification

Tcf Trillion Cubic Feet 



\section{mission}

DOE's Industrial program, in partnership with industry and stakeholders, supports research, development, demonstration, and deployment efforts for development of cost-effective, energy-efficient industrial technologies. The Industrial program supports efforts to promote efficiency in energy use and diversity in energy sources in the eight major natural gas consuming industries -- iron and steel, chemicals, petroleum refining, food processing, textiles, pulp and paper, glass, and aluminum.

\section{vision: 2025}

Industry is maximizing utilization of natural gas because of its costeffectiveness, energy efficiency, and environmental benefits. Natural gas is used extensively for primary or intermediate feedstocks in industrial processes. 
5-2 


\section{situation analysis}

\section{mandates}

Mandates for the Industrial program include: the Energy Policy Act of 1992 (P.L. 102-486), Metal Casting Competitiveness Act of 1990 (P.L. 100-425), Steel and Aluminum Energy Conservation and Technology Competitiveness Act of 1988 (P.L. 100-680), Federal Grant and Cooperative Agreement Act of 1977 (P.L. 95-224), Federal Non-Nuclear Energy Research and Development Act of 1974 (P.L. 577), and the Clean Air Act Amendments of 1990 (P.L. 101-549).

\section{program relationships}

The Office of Energy Efficiency and Renewable Energy (Energy Efficiency) supports research, development, and demonstration (RD\&D) efforts that can improve the Nation's energy future. Energy Efficiency, in coordination with other offices (e.g., Offices of Fossil Energy, Energy Research, and Policy), concentrates its efforts on improving energy efficiency and productivity in the industrial sector of the economy. To be certain that its programs continue to be responsive to the long-term needs of its customers, Energy Efficiency launched the "Industries of the Future" initiative. This initiative strengthens collaboration between industry and government and promotes leveraging of RD\&D resources. Industries of the Future is a process in which industry participants, facilitated by DOE, create a vision that reflects the diverse technological, economic, and environmental drivers that are shaping the future of their industries. The vision provides a framework for shaping major advancements in technologies according to their potential for improving industrial efficiency, energy and materials use, and environmental protection.

Industry "Visions of the Future" documents are being developed by the most energy intensive industries in the U.S., namely, the chemicals, petroleum refining, steel, glass, aluminum, metal casting, and forest and paper industries. These industries account for over 90 percent of the energy used in the U.S. manufacturing sector. The Vision documents will be developed by an industrial champion and subjected to peer review with others in the industry, (e.g., industry suppliers and customers). Each Vision document will characterize the industry today, identify trends and drivers, and characterize the industry 25 years in the future. The Industries of the Future strategy will nurture a more holistic perspective through intra- and interagency alliances within government including the Department of Energy, the National Aeronautics and Space Administration (NASA), Department of Defense (DOD), and Department of Transportation (DOT), as well as State and local governments, and non-government organizations such as the Gas Research Institute (GRI) and the Energy Power Research Institute (EPRI). 


\section{current situation}

The industrial sector is an important market for the natural gas industry. Eight major gas consuming industries -- iron and steel, chemicals, petroleum refining, food processing, textiles, pulp and paper, glass, and aluminum -- account for 90 percent of industrial gas consumption. These eight industries represent a wide variety of products, processes, and uses of natural gas.

Natural gas consumption in the industrial sector has been increasing 6 to 7 percent annually since 1986 , but slowed to a growth rate of 4 percent, yielding a total consumption of 7.5 trillion cubic feet (Tcf) in 1992. However, in 1993 total consumption reached 7.9 Tcf, an increase of 6 percent annually. Industrial sector consumption in 1993 represented 43 percent of the U.S. gas demand. Much of the increase during the previous six years can be attributed to iatural gas consumption by nonutility generators (NUGs). While natural gas consumption in industry has been increasing overall, consumption per customer has decreased steadily and dramatically for the past 20 years. Average consumption per industrial customer in 1993 was only 31 percent of the 1973 level. This illustrates the shifting industrial base and the decreasing energy intensity of industrial processes.

Natural gas is used both as a raw material in the chemical industry and as a fuel in other industrial applications. Approximately 27 quadrillion Btu of energy were used in manufacturing in 1993, about 80 percent of the amount in all industrial Standard Industrial Classifications (SICs). Within manufacturing, energy use is concentrated in a relatively small number of SICs. Pulp and paper, metals, chemicals and petroleum refining, stone, clay and glass, and food processing account for over 90 percent of all the energy used in manufacturing.

The manufacturing sector spent over $\$ 130$ billion on energy in 1990 , and $\$ 30$ billion on treatment, storage, and disposal of waste. This represents about 6 percent of the value of all manufactured products sold. In the last 10 years, energy has become less important as a driver of U.S. industry investment decisions as natural gas, electricity, and imported oil have been readily available at attractive prices and energy costs have been declining as a percent of product selling price.

Manufacturing industries use the bulk of the natural gas in the industrial sector primarily for process heating and steam generation (including cogeneration). Process heating uses of natural gas are extremely diverse, and include glass melting; heating and melting of metals; calcining and drying of minerals, foodstuffs and chemicals; liquid heating; and waste incineration and vitrification. Much of the boiler portion of the steam generation market and some process heat applications such as fluid heaters in refineries typically have dualfuel capability and are extremely competitive fuel markets.

On the other hand, users prefer natural gas in many process heating applications because of its clean burning characteristics and ease of use. About 10 percent of natural gas 
consumption in manufacturing industries is as feedstocks, primarily for ammonia-based fertilizers, methanol, acetylene, and production of hydrogen gas. (Source: Energy Information Administration, Manufacturing Energy Consumption Survey, 1991)

\section{DOE position}

Natural gas is an important energy option for the industrial sector and has long been a preferred fuel for many industrial users. DOE is promoting cost-effective advanced natural gas technologies in the industrial sector to enhance economic growth and competitiveness by directly supporting and accelerating demonstration, commercialization, and deployment of new and innovative technologies.

The industrial energy market is the most competitive sector served by the natural gas industry. As an example, natural gas is facing increasing competition from electricity in the process heating market where natural gas traditionally has been the preferred fuel. In general, decisionmakers in the industrial sector have become sophisticated energy and process equipment buyers and have a wide range of alternatives. Additionally, the industrial sector has undergone major restructuring during the past decade with the emergence of a world market where quality and productivity have become dominant considerations in business decisionmaking along with the need to control costs and improve operational efficiency. Although manufaciurers are still heavily motivated by return on investment in making capital investment decisions related to energy equipment, the increasing need to meet world class standards and to respond to environmental concerns is making the energy decision process more complex.

Energy decisions are increasingly subordinate to overall economic considerations. Process equipment that can offer competitive advantages in terms of productivity, product quality or environmental compliance will be adopted regardless of the energy source. There are new natural gas technologies under development that may lead to increases in natural gas demand in particular industries or applications.

\section{stakeholder considerations}

Industrial Customers: Industrial customers use natural gas as fuel and feedstock. Natural gas typically is a small fraction of production costs but is critical to the production process. Improved utilization of natural gas to reduce costs and increase productivity of invested equity is the driver.

Pipelines: Pipeline companies rely on the industrial community for materials and control technology. Investments in these areas will help improve the cost-effectiveness of pipeline companies with benefits that will ripple through to the consumer.

\section{Local Distribution Companies (LDCs):}

Local market share for LDCs is tied directly to competitiveness of the industrial customers 
they service. Investments in technology development to make industry more costcompetitive provide an economic infrastructure for all to prosper.

\section{Environmental and Energy Efficiency}

Organizations: These groups are pressing for reduced emissions. Increased utilization of natural gas through cost-effective technology will help stabilize the natural gas market and be responsive to the Clean Air Act Amendments of 1990 (CAAA).

Federal, State, and Local Regulatory Agencies: These groups develop regulations out of legislative mandates that will be influenced greatly by technology available for cost-effective compliance by industry. Natural gas technologies typically set the standard for regulations concerning combustion systems.

Investment Community: Lenders and investors have vested interest in competitiveness of the industries they finance. Natural gas technologies must continue to be proven as a cost-effective approach to meeting the environmental compliance cost burden.

Congress: The U.S. Congress formulates national environmental and energy policy through both its legislative and oversight activities. Congress must work with each of the stakeholders to ensure that energy legislation is both environmentally and economically feasible. Through open communication with all natural gas stakeholders, Congress continues to pursue ways to remove unnecessary statutory barriers to market development.

\section{key trends}

\section{technology}

- There are continued opportunities for additional natural gas-fired cogeneration applications in the industrial market. Exploiting these markets will require research and development on improved gas-based technologies that reduce capital cost, increase productivity, product quality, and efficiency while meeting increasingly stringent emission regulations.

- New natural gas technologies are under development that match electricpowered equipment in precision of control, productivity, and product quality.

- Expanded natural gas use has been constrained by the perception that electric technologies are more controllable and, therefore, more amenable to advanced automated equipment and processes and better able to increase productivity and product quality. 
- Industrial users are conservative, risk averse, and, in general, capital constrained; and industrial equipment is, in general, expensive. There is a great reluctance to invest large sums of money in new technologies that have not been proven in a production environment. There is a growing need in this market for demonstration programs of advanced technologies to document performance in various operating modes and applications, and to verify the economics and reduce the perceived risk of the technology to the user.

- Natural gas companies are expanding into the production of electricity as a result of increased competition in both industries.

\section{market}

- Natural gas is already an important contributor to the Nation's energy supply, and about 43 percent of U.S. gas consumption is in the industrial sector. The industrial sector uses natural gas for a wide variety of applications including generating steam and hot water, powering engines and turbines, heating metals and plastics, melting glass and aluminum, and serving as a feedstock for fertilizers and hydrogen gas.
- $D O E$ is recognizing ongoing efforts by industry and other stakeholders and is focusing its efforts on those areas that will benefit from the additional resources that the Federal government could provide and that offer clear national benefits in terms of environmental quality, energy security, and industrial competitiveness.

- The increased complexity of purchasing natural gas is a cost incurred by the users, and small industries may find the system unwieldy and could turn to alternative fuels and technologies. Much of the industrial market is dual-fuel capable and extremely price sensitive.

Natural gas will need to remain competitively priced to maintain or increase market share in such applications.

- The industrial base is moving away from energy-intensive industries, such as iron and steel, to less energyintensive industries, such as electronics and pharmaceuticals. 


\section{policy/regulatory}

- Lingering perceptions about natural gas supply, price, and reliability continue to affect fuel selection in the industrial sector. In addition, increased competition in the gas transmission system and unbundling of services has made natural gas purchasing more complex and uncertain, particularly through the restructuring transition period.

- Industrial customers, especially the larger and more sophisticated users, have benefited from increased competition in the natural gas industry. Unbundling/rebundling of natural gas transportation service has increased the natural gas purchasing options available to industrial customers, resulting in lower prices to industrial customers.

\section{environment}

- Natural gas does not receive proper credit for its economic and environmental efficiencies and, therefore, some industrial users may find it more attractive to use electricity, which has no emissions at the site, than to obtain the offsets necessary to increase natural gas consumption.

\section{key planning assumptions}

\section{technology}

- Continued development and commercialization of advanced natural gas technologies will promote growth in industry.

- Utilization of advanced natural gas technologies will provide higher efficiencies and lower emissions as well as providing economic benefits to the industrial sector.

\section{market}

- Growth in industrial natural gas demand (including cogeneration) will continue at a módest pace, restrained by technological advances in industrial processes, the use of more efficient equipment, and a shift in the U.S. industrial base. 


\section{policy/regulatory}

- Restructuring of the electricity industry will affect natural gas use in the industrial sector. To the extent that developments on the electric side result in price decreases, natural gas faces stiffer competition.

- Pressure to reduce end-use emissions at industrial sites enhances natural gas use in the power generation sector.

- Failure to consider life-cycle costs of energy at the point of consumption may cause industries to use electricity.

\section{environment}

- Environmental pressures, while considered to be a driver for expanded natural gas use in the industrial sector, also can act as a potential barrier. Environmental requirements for new and modified facilities most likely will continue to be more stringent. 
5-10 


\section{strategic issues}

\section{technology}

- Barriers to increased natural gas use include the perception that electric technologies are more controllable and, therefore, more amenable to advanced automated equipment and processes and better able to increase productivity and product quality.

- Industry will adopt new manufacturing equipment and processes only when that equipment is more productive and cost-effective and enables the user to compete more efficiently.

- Process equipment that can offer competitive advantages in terms of productivity, product quality or environmental compliance will be adopted regardless of the energy source.

- Lack of university-level degree programs emphasizing "natural gas engineering," especially those on end-use applications, are inhibiting technology development.

\section{market}

- Increased uncertainty and misinformation concerning the future reliability, availability, and price of natural gas among industrial fuel buyers, plant managers, and other senior industrial executives could hinder the use of natural gas in new industrial applications.

- Substitution by other fuels in multiple fuel capable facilities is a major threat to industrial natural gas markets.

- Market introduction of new technologies is often impeded by the high costs of initial units and the reluctance of the marketplace to accept risk associated with a new product or equipment, which results in a growing need in the industrial market for advanced technology demonstration programs.

- The key to reaping the potential benefits of increased utilization of natural gas is maintaining a safe, reliable, and cost-effective transmission and distribution system.

- While it is likely that the strategies developed by the natural gas industry to maintain the volume of gas deliveries in the industrial sector will be primarily motivated by the need to retain customers and retain load, opportunities exist to expand the use of natural gas in existing and new markets. 


\section{policy/regulatory}

- Environmental issues, policies, and programs continue to increase the demand for natural gas use, while locally posing a threat to those industries utilizing natural gas as a power source due to locally stringent emission requirements, particularly in the CAAA ozone nonattainment areas.

\section{environment}

- Strict nitrogen oxides $\left(\mathrm{NO}_{\mathrm{x}}\right)$ emission standards could negatively impact existing high-temperature gas processes.

- Natural gas demand may be particularly at risk in ozone nonattainment areas where there is a greater than one-for-one $\mathrm{NO}_{x}$ offset requirement. As environmental requirements continue to tighten, increased pressure may be placed on industrial gas customers to reduce all on-site fuel consumption including natural gas.

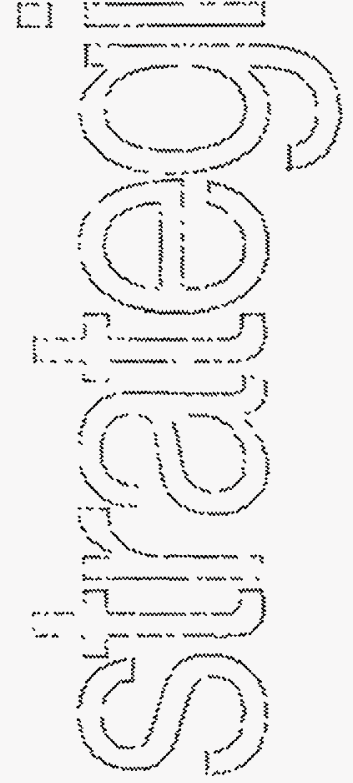




\section{program goals and strategies}

To implement the vision of optimizing natural gas use in the industrial sector, DOE has established four goals: (1) developing technology, (2) deploying technology, (3) removing policy impediments, and (4) ensuring maximization of the environmental benefits of natural gas in the industrial sector.

\section{technology}

Goal: Support the development of advanced technologies in the industrial sector necessary to achieve the economically efficient use of natural gas.

\section{Strategy:}

- Assist industry in identifying, researching, and developing promising technologies.

Goal: Develop cost-effective, energy-efficient technologies that utilize natural gas and provide industry with a competitive advantage and environmental benefits.

\section{Strategies:}

- Incorporate technology transfer up-front by having industry actively participate in the research effort and have industry provide a test site for scaleup and field testing in addition to market entry.

- Increase the energy efficiency and economic competitiveness of energy-intensive industries through development of new or modified processes, advanced materials, and process sensors and control systems.

\section{market}

Goal: Foster the adoption and use of technologies in the industrial sector necessary to achieve the economically efficient use of natural gas.

\section{Strategies:}

- Assist the natural gas industry in identifying, developing, and disseminating information describing the benefits of natural gas use in the industrial sector.

- Assist the natural gas industry in funding the demonstration of new natural gas technologies in the industrial sector. 
- Encourage the purchase of natural gas industrial technologies by Federal, State, and local governments.

\section{policy/regulatory}

\section{Goal: Support the economically efficient} use of natural gas in the industrial sector and work to remove policy and regulatory impediments to natural gas use.

\section{Strategies:}

- Identify and analyze impediments to natural gas use in the industrial sector and the policies required to remove those impediments.

- Recommend appropriate actions to promote natural gas use or to remove impediments to gas use in the industrial sector.

- Assist in the implementation of policy changes to remove impediments and promote the efficient use of natural gas in the industrial sector.

\section{environment}

Goal: Promote the maximization of environmental benefits of natural gas use in the industrial sector.

\section{Strategies:}

- Assist the natural gas industry in the development of technologies, for the industrial sector, that enhance environmental quality.

- Assist the natural gas industry in developing and disseminating information on the environmental benefits and impacts of natural gas use in the industrial sector.

- Assist the natural gas industry in ensuring that the environmental benefits of natural gas use in the industrial sector are not impeded by regulatory or other policies.
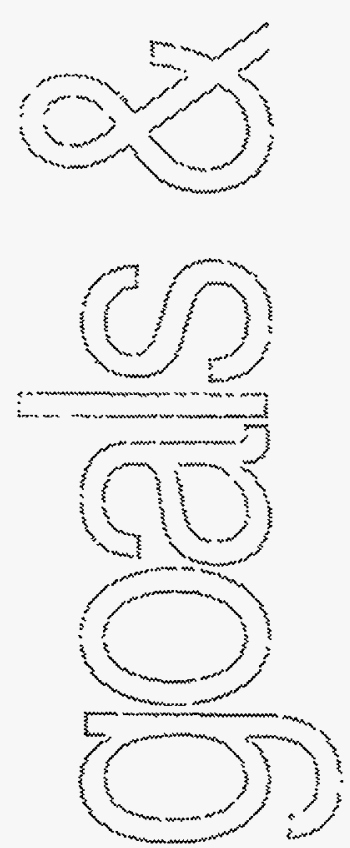


\section{performance indicators}

- Increased rate of adoption of energy-efficient technologies by industry. (Near-Term)

- Increased number of commercially viable energy-efficient technologies developed. (Near-Term)

- Increased rate of development and adoption of leading-edge, energy-efficient industrial technologies. (Mid-Term)

- Increased industry/government partnerships for advanced natural gas technology research, development, and demonstration. (Mid-Term)

- Continuous improvement in industrial infrastructure competitive position because of early adoption and implementation of energy-efficient, cost-effective and environmentally acceptable technologies. (Long-Term)

\section{General Indicators}

- Decrease in energy use per unit of production.

- Improved ratio of unit of production to processing cost.

- Tons of air emissions avoided.

- Percentage of industrial base that is addressed by alternative technologies developed.

- Number of projects and cost-shared government/industry partnerships. 
5-16 


\section{program overview}

program activities summary

DOE's natural gas program consists of elements supported by the Offices of Energy Efficiency and Renewable Energy, Fossil Energy, and Energy Research. The primary focus of the work is to develop advanced high efficiency, low pollution, natural gas technologies and to commercialize these technologies in the industrial sector. Following is a brief summary of program activities:

Improved Combustion Efficiency (Energy Efficiency): The cost-effective minimization of combustion emissions while at least maintaining, if not increasing, the efficiency of combustion from gas-fired combustion systems is the overall goal of industrial combustion research. The program uses combustion fundamentals to address this goal and pursue new combustion concepts with favorable energy and environmental characteristics that can be developed into end-user equipment. Cost-effective minimization of $\mathrm{NO}_{x}$ emissions in the combustion process is the ultimate goal.

Glass Industry (Energy Efficiency): In 1991, the worldwide glass market totaled approximately $\$ 44$ billion, consuming approximately 300 trillion Btu of energy. The key drivers for the glass industry are generally attributed to market competition, government safety and environmental regulations, and energy cost and availability. The goal of the program is to improve energy efficiency and productivity while simultaneously protecting the environment through pollution prevention. Improving the productivity and reducing emissions within the glass industry has the potential to save approximately 45 trillion Btu of energy while reducing emissions by approximately 80 percent.

Hydrogen Research and Development (Energy Efficiency): Hydrogen is one of the most suitable energy sources for the technological and environmental perspectives of the next century. Hydrogen provides a flexible way of storing and using electric energy, diversifies energy supply sources, and can reduce the effects of pollution linked to the use of fossil fuels. The program will develop the concept of absorbing carbon dioxide in the reaction zone of a steam methane reformer using adsorbent material. The objective is to develop high efficiency, lower temperature conversion processes for hydrogen using natural gas as the feedstock to accelerate interest in near- and mid-term energy applications for hydrogen. 
Fundamental Chemical Research (Energy Research): The catalytic mechanisms for the synthesis of higher molecular weight hydrocarbons and other organic compounds from methane as well as chemical processes on surfaces during combustion are not well understood. The program focuses on supporting fundamental, experimental, and theoretical research on the chemistry relating to catalysis of methane, and the factors affecting combustion of methane in flames, industrial combustors, and internal combustion engines.

\section{Advanced Turbine Systems (Fossil} Energy, Energy Efficiency): The program goals are to design, develop, and demonstrate advanced turbine systems that will be ultra-high efficiency, environmentally superior, and will produce electricity costing 10 percent less at the busbar. Improvements in component materials and combustor, and turbine and system design will be integrated into systems utilizing compressor intercooling, high temperature, multi-stage gas turbines and high performance steam generators and turbines. While system design will differ between manufacturer and target application, the program will address aeroderivative and heavy frame turbine designs. The efficiency goal for the utility class gas turbine is 60 percent for the industrial turbine, an improvement of 15 percent is sought over current models. Emissions of $\mathrm{NO}_{\mathrm{x}^{\prime}}$ carbon monoxide (CO), and unburned hydrocarbons are to be reduced to less than $10 \mathrm{ppm}$.
Cogeneration (Energy Efficiency, Fossil Energy, Energy Research): Gas turbines are used internationally for electrical service, cogeneration, mechanical power drives, and offshore power generation. Nationally, there is about 65,000 megawatts of operating gas turbine capacity. The objective of this program is to insert ceramic components in critical locations of stationary gas turbines for cogeneration service, achieving considerable fuel savings and reduced emissions. Benefits of ceramic components include: more than 40 percent thermal efficiency; ultra-low $\mathrm{NO}_{x}$ potential with ceramic combustor; engine cost reductions by replacement of cooled single crystal and directionally solidified parts with uncooled ceramics; and lower cost per installed kilowatt of capacity.

\section{Continuous Fiber Ceramic Composites}

(Energy Efficiency): The objective of this program is to develop advanced structural materials with improved high temperature, wear resistant, noncorroding characteristics that open up new opportunities because of their ability to perform in environments and under operating conditions that would destroy currently available metals and ceramics. Potential benefits include approximately 2.22 quadrillion Btu reduction in the annual national energy consumption, and 0.98 million tons/year of $\mathrm{NO}_{x}$ and 110 million tons/year of carbon dioxide $\left(\mathrm{CO}_{2}\right)$ emission reductions. 
Advanced Industrial Materials (Energy

Efficiency): Materials are necessary in every phase of manufacturing from raw materials through synthesis and processing, to industrial or commercial application, and ending as waste or recycled material for reuse. Not only are advanced materials critical for product development, but also they are essential for improving manufacturing processes and reducing energy consumption. Industries engaged in fabrication and assembly of consumer products also will benefit significantly from the use of advanced materials to improve process efficiency and productivity through reduced life cycle energy use, higher processing temperatures, increased component and system lifetimes, and reduced downtime.

\section{Pressure Calciner for Alumina (Energy}

Efficiency): The major program goal is improved energy efficiency and fuel flexibility in the industrial sector by conducting an aggressive cost-shared government/industry research and development program aimed initially at industrial processes in energyintensive industries. The aluminum industry is the focus of these efforts by developing a cost-effective, energy-efficient pressure calciner viable for retrofit and greenfield applications (new production facilities) for the production of alumina.
Advanced Process Controls (Energy Efficiency): The U.S. steel industry is an energy-intensive industry and a major consumer of natural gas, consuming approximately 1.8 quadrillion Btu annually. The development of sensors and control systems have the potential to increase the efficiency of steelmaking as well as increasing the yield. Efforts are focused on performing research and development and industrial demonstrations to produce a series of sensors and controls to facilitate computer automation of the steel industry to increase quality and yield.

\section{Anaerobic Digestion (Energy Research):}

Current practice is to dump tuna sludge at sea and biodegradable municipal solid waste into landfills. Landfills are essentially uncontrolled digesters that generate and emit methane, a greenhouse gas. In order to minimize landfill greenhouse gas emissions, anaerobic digestion vessels could be used to produce and collect methane for use as fuel from biodegradable wastes. 
Active Transport Membrane (Fossil Energy, Energy Efficiency): Active transport membranes can be used for the separation of ammonia $\left(\mathrm{NH}_{3}\right)$ from hydrogen gas mixtures, and the separation of acid gases, such as hydrogen sulfide $\left(\mathrm{H}_{2} \mathrm{~S}\right)$, and $\mathrm{CO}_{2}$ from a variety of gases and natural gas. The objective of this program is to develop active transport membranes based on encapsulation of novel chemical absorbents for ammonia and acid gases. Advanced transport membranes utilized in synthesis and production of hydrogen and ammonia plants, and ammonia product recovery for ammonia plants and the removal of $\mathrm{CO}_{2}, \mathrm{H}_{2} \mathrm{~S}$ from natural gas, could save approximately 14 billion Btu of energy annually.

\section{Industries of the Future (Energy}

Efficiency): An objective of this program is to support the implementation of highefficiency natural gas technologies, which provide cost-effective, energy-efficient, environmentally viable solutions for industry to meet new regulations and improve process efficiency. The program has initiated workshops and industrial interactions aimed at identifying research and development activities that will increase the energy efficiency and economic competitiveness. Future efforts within Energy Efficiency for industrial utilization of natural gas will be directly related to the "Visions of the Future" strategy for the energy-intensive industries.
The International Center for Gas Technology Information (Fossil Energy): The International Centre for Gas Technology Information (the Center or (CGTI) is an outcome of the recommendations following the International Energy Agency's (IEA) 1990 conference in Lisbon, Portugal, on emerging natural gas technologies. With the support of DOE and the Danish Ministry of Energy, GRI and the Danish Gas Technology Centre a/s, formed a joint corporation, Gas Technology Information, Inc. (GTI), as the operating agent for the Center. The Center was formally established in April 1995. GTI, with offices in Horsholm, Denmark; and Washington, DC, currently operates the Center on behalf of the member countries and the IEA. ICGTI's current charter members include U.S., Russia, Japan, Spain, Denmark, and Portugal. Initial U.S. support for the Center was through a DOE grant to GTI to establish the U.S. office and to fund the U.S. commitment for the preliminary program. Funding for the program activities is based on a formula agreed upon by all of the participating countries. 
The Center will promote widespread commercialization of gas-related technologies by providing a continuing international forum where increased information dissemination and international cooperation and collaboration concerning natural gas technologies can take place. To increase the rate of technological innovation for the global gas industry, the Center will perform three primary functions: (1) technology information exchange; (2) technology analysis; and (3) technology transfer. The Center also offers a global information exchange, called "GTI Online," an Internet-based system. The benefits of GTI Online include the following: (1) access to worldwide natural gas industry and technology information specifically designed to meet the industry's needs; (2) opportunity to collaborate internationally with experts in selected fields; and (3) opportunity to gather marketing intelligence on and access to potential customers, competition, and key decisionmakers; and (4) opportunity to promote equipment and services worldwide.

\section{FY 1994-1996 budget summary}

(Dollars in Million)

\begin{tabular}{|l|c|c|c|}
\hline DOE Office & $\begin{array}{c}\text { FY 1994 } \\
\text { Actual }\end{array}$ & $\begin{array}{c}\text { FY 1995 } \\
\text { Approp. }\end{array}$ & $\begin{array}{c}\text { FY 1996 } \\
\text { Request }\end{array}$ \\
\hline Energy Efficiency & 14.0 & 14.8 & 24.2 \\
\hline Energy Research & 4.5 & 4.7 & 4.8 \\
\hline Total DOE & 18.5 & 19.5 & 29.0 \\
\hline
\end{tabular}

1 Appropriation 
19. 


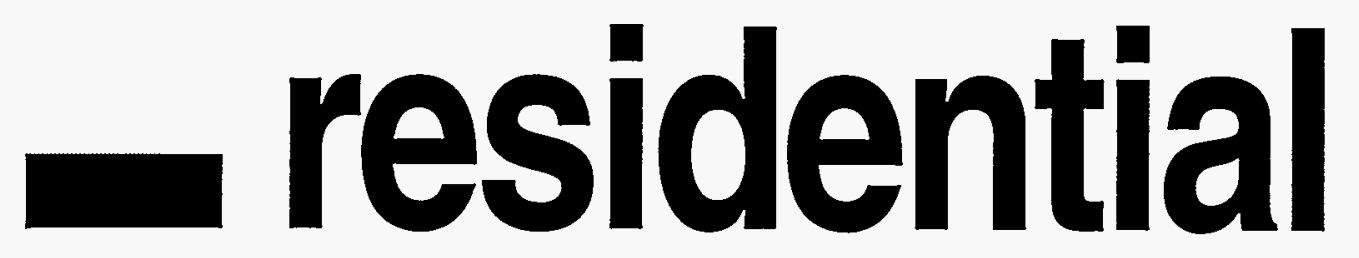
and

commercial 



\section{Page No.}

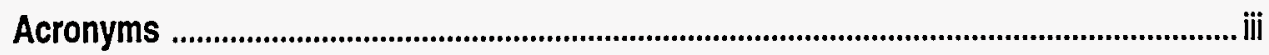

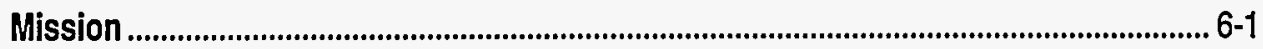

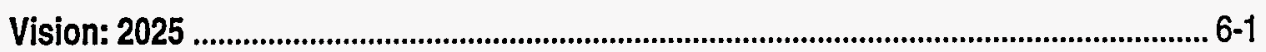

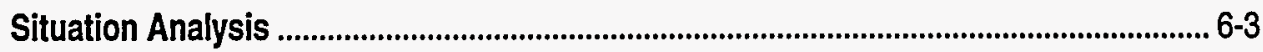

Mandates .................................................................................................................... 6-3

Program Relationships ..................................................................................................... 6-3

Current Situation ............................................................................................................. 6-4

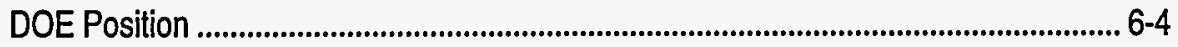

Stakeholder Considerations ............................................................................................. 6-5

Key Trends .................................................................................................................... 6-5

Key Planning Assumptions .................................................................................... 6-6

Strategic Issues ...................................................................................................................... 6-9

Program Goals and Strategies .......................................................................................... 6-11

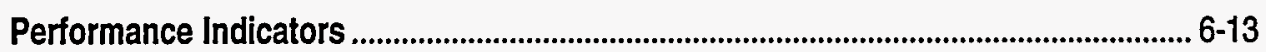

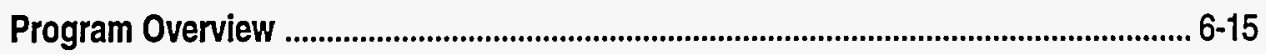

Program Activities Summary ........................................................................................ 6-15

Changes from Previous Plan .................................................................................... 6-16

FY 1994-1996 Budget Summary ..................................................................... 6-16 



\begin{tabular}{ll} 
AGA & American Gas Association \\
Btu & British Thermal Unit \\
CFC & Chlorofluorocarbon \\
$\mathrm{CO}_{2}$ & Carbon Dioxide \\
COP & Coefficient of Performance \\
DOE & Department of Energy \\
DSM & Demand-Side Management \\
EPACT & Energy Policy Act of 1992 \\
EPRI & Electric Power Research Institute \\
GAX & Gas-Fired Absorption Heat Pump \\
GRI & Gas Research Institute \\
HCFC & Hydrochlorofluorocarbon \\
KW & Kilowatt \\
NAECA & National Appliance Energy Conservation Act \\
NEPA & National Environmental Policy Act \\
NO & Nitrogen Oxides \\
R\&D & Research and Development \\
SO & Sulfur Oxides \\
\hline
\end{tabular}




\section{mission}

DOE's Residential and Commercial program, in partnership with industry and stakeholders, undertakes activities to develop advanced natural gas technologies and promotes policies to increase the economically efficient utilization of natural gas in commercial and residential buildings. The program supports cost-shared research, development, and commercialization of high-efficiency gas-fired heating, cooling, and major appliance technologies. Through partnerships with industry, the program aims at improving buildings sector energy performance, environmental quality and occupant productivity, and establishing U.S. leadership in a growing world marketplace for building equipment and appliances.

\section{vision: 2025}

Natural gas is available universally within the buildings sector as a result of infrastructure expansion. Natural gas is recognized as a safe, economically competitive, and environmentally sound energy resource for use in building space conditioning, and appliance operation. Natural gas-driven fuel cells sited within buildings are viable alternatives to centralized utility generation as sources of electricity for residential and commercial buildings. 



\section{situation analysis}

\section{mandates}

The program will comply with all applicable Federal, State, and local laws and regulations, and Administration and DOE regulations and policies, including: the Energy Policy Act of 1992 (Title XXI-Energy and the Environment, Section 2102: Natural Gas and Electric Heating and Cooling Technologies, Section 2104: Advanced Buildings for 2005); Climate Change Action Plan (Action 1: Rebuild America, Actions 4 and 6: Building Equipment Market Transformation, Actions 8 and 11: Residential Energy Services, Action 9: Cool Communities, and Action 10: Upgrade Building Codes and Standards); DOE Organization Act (Public Law 95-91); and the National Environmental Policy Act (NEPA).

\section{program relationships}

The Residential and Commercial program resides within the Office of Energy Efficiency and Renewable Energy and its implementation is coordinated with the Office of Policy. The key to the Residential and Commercial program lies in the continued development of collaborative relationships with industry, utilities, State and local governments, other Federal agencies, and other interested parties within the building industry. These relationships are fostered through a Federal research and development (R\&D) process that includes: initial assessment of technology needs; establishment of Federal program priorities and adequate funding levels; partnerships with industry to jointly fund R\&D and commercialization activities; technology transfer; and program assessment. This collaboration provides DOE and its industry partners with an excellent opportunity to share development costs, assure that programs are meeting the needs of both industry and end users, and accelerate the benefits that can be realized as a result of combined energy efficiency development programs, while also achieving the Nation's goal of increasing the efficient use of natural gas. The market entry and acceptance of advanced natural gas technologies could be substantially accelerated by cooperative efforts between government and industry. Private sector cooperative funding of the research, development, and demonstration phases of technology development must be part of a continuum that also includes cooperation during the final commercialization phase to realize the technology objective that justified Federal participation during the research phase.

The Department's efforts to address natural gas-fired building equipment are coordinated with research and development activities of the Gas Research institute (GRI), American Gas Association (AGA), and the Electric Power Research Institute (EPRI). GRI has a multimillion dollar research program that is focusing on building equipment and appliance energy performance and is closely coordinated with DOE. Similarly, AGA supports advanced natural gas cooling and dehumidification technology R\&D. DOE, the natural gas industry, and EPRI are conducting research on fuel cells for building applications. 
Many State and local government agencies implement programs and regulations that impact the use of natural gas in buildings, such as air quality standards and requirements for utility Demand-Side Management (DSM). The Department takes these activities into account when assessing technology needs and program priorities.

\section{current situation}

In 1993, the U.S. buildings sector used approximately 31.4 quadrillion Btu of primary energy, of which over 32 percent was supplied by natural gas. Residential buildings consumed 18.1 quadrillion Btu of energy in 1993, while 13.3 quadrillion Btu was used within commercial buildings. The buildings sector is responsible for two-thirds of the Nation's electricity demand. Space heating is the single largest end-use energy demand within buildings, accounting for 37 percent of residential building energy consumption and 18 percent of commercial building energy consumption. Space cooling and ventilation represents an additional 14 percent of commercial building energy use.

Lower operating costs, compared to competing fuels, and expanded distribution systems contribute to the competitiveness of natural gas for space heating and water heating applications. However, the higher first-costs that are typical for natural gas-fired cooling technologies and appliances compared to competing equipment often act as a purchase barrier, particularly in new construction markets.

\section{DOE position}

Section 127 of the Energy Policy Act of 1992 (EPACT) specifically directs DOE to assess the potential for the development and commercialization of natural gas-driven building appliances, including heating and cooling equipment, that are substantially more efficient than those required by Federal or State laws, and to recommend specific actions that DOE could take in assisting utilities and appliance manufacturers in product development and commercialization.

In implementing the requirements of EPACT, Section 127, a significant part of DOE's program will target technical and market obstacles that impede the adoption of advanced building equipment and appliance technologies.. Joint DOE/industry participation in efforts to develop and deploy high performance natural gas-driven products is a critical element in fostering the enhanced use of natural gas within the buildings sector.

Therefore, DOE seeks to: (1) support development of cost-effective advanced natural gas technologies for space conditioning and water heating; (2) establish partnerships with industry to promote and accelerate natural gas technologies to meet the provisions for air quality goals; (3) support deployment and integration of advanced utilization technologies, including cogeneration systems using gas turbines, fuel cells, and chillers in the building sector; and (4) advance the state-of-the-art in computing and information technologies to assist in full integration of natural gas systems. 


\section{stakeholder considerations}

Residential and commercial building stakeholders include equipment manufacturers, building energy equipment specifiers, energy suppliers, regulators and policymakers, public interest groups, State and local governments, gas consumers, and the investment community.

Stakeholder interactions are increasing, signaling a renewed commitment to close consultation and partnership. Stakeholders help DOE gain a better understanding of energy trends and the market, leverage knowledge and financial resources, and plan collaborative relationships that include an appropriate balance between near- and longterm goals. State and local governments have two additional roles in assisting stakeholders with policy implementation: through State adoption of these programs and by direct involvement in technology deployment.

\section{key trends}

\section{technology}

- The energy performance of natural gas heating and cooling equipment has improved significantly over the past ten years. There is, however, room for additional improvements that could result from more advanced equipment and control technologies.

- The energy performance of building envelopes and systems also has improved in recent years, and will continue to do so, as new window and construction material technologies are deployed and new construction techniques result in better insulated (tighter) buildings.

- Prior to the early 1970 s, U.S. manufacturers virtually were without foreign competition in the commercial space cooling market. Since that time, foreign manufacturers have made incremental improvements in many U.S.-pioneered technologies, and now dominate the international market for large commercial cooling products. 


\section{market}

- Overall energy consumption within the buildings sector is continuing to rise as a result of population growth, demographic shifts to coolingdominated regions of the country, and increased use of electricity associated with the evolution of the information age (e.g., office equipment, communications).

- Increased worldwide demand for energy-consuming products is creating an expanding market for high performance building equipment and services.

\section{policy/regulation}

- The Federal government is continuing to promulgate minimum energy efficiency standards for many types of building equipment and appliances. These actions have removed numerous low-end efficiency products from the market.

- Increasingly competitive conditions in electricity and natural gas utility markets are causing some utilities to shift away from DSM programs.

\section{environment}

- Increasingly stringent environmental regulation on the emissions of sulfur oxides $\left(\mathrm{SO}_{\mathrm{x}}\right)$ and nitrogen oxides $\left(\mathrm{NO}_{\mathrm{x}}\right)$ and other unburned hydrocarbon gases offer opportunities for increased use of natural gas equipment and appliances in buildings.

- Elimination of ozone-depleting chemical refrigerants is accelerating the development of alternative products, including natural gas-driven absorption cycle refrigeration technology, which do not rely on the use of environmentally harmful chemicals.

\section{key planning assumptions}

\section{technology}

- Although significant advancements in building equipment technology have been incorporated into the current product mix, energy savings potential remains.

- The energy performance of the next generation of natural gas-fired building equipment is projected to be higher than the best available products currently on the market. Advanced gas-fired heat pumps currently being developed by major manufacturers are more than twice as efficient, on a primary energy basis, as the best currently available electricitydriven units. 


\section{market}

- There is a substantial worldwide market for more energy-efficient building equipment (especially in developing countries of the Far East).

- Residential and commercial buildings can be made much more energy-efficient without deleterious effects on occupant comfort, health, or productivity.

- Targeted marketing by natural gas companies will result in continued expansion of the distribution infrastructure, with service becoming available to previously unserved residential and commercial buildings.

\section{policy/regulation}

- The requirements of Section 127 of EPACT will continue to foster costsharing relationships designed to accelerate both the development and commercialization of technology that is significantly more energy-efficient than the best currently available products.

\section{environment}

- The more efficient use of natural gas in residential and commercial buildings will contribute significantly to reductions in carbon dioxide $\left(\mathrm{CO}_{2}\right), \mathrm{SO}_{\mathrm{x}}$, and $\mathrm{NO}_{\mathrm{x}}$ emissions, a primary goal of the President's Climate Change Action Plan. 
6-8 


\section{technology}

- The purchase cost of highly efficient natural gas-driven equipment often inhibits its selection, even though it may offer the lowest life-cycle cost.

\section{market}

- A wide array of technically proven, highly energy-efficient building products are currently available in the markeiplace, but are underutilized because the new technology is more expensive than existing lower efficiency products.

- When compared to other energy-consuming elements (e.g., automobiles) in the U.S. economy, residential and commercial buildings are among the most enduring. Typically, buildings last an average of fifty years, with some having useful lives much longer than that. A large percentage of the existing building stock reflects design and construction practices from a period in time when energy and the environment were a lower priority than today.

- The development of advanced building equipment technologies is inhibited by inherent high risk and low private sector budgets for R\&D, which stems from U.S. industry's focus on short-term return on investment.

- High levels of competition within the residential and commercial building equipment industries limit opportunities for industry cooperation and coordination in the development of advanced technologies.

- The residential and commercial building industry encompasses a vast array of decisionmakers, both corporate and individual. This often leads to fragmentation in purpose and implementation of a cohesive strategy to improve the energy performance of the buildings sector.

- There is a lack of awareness on the part of the end user about the range of natural gasdriven products that are currently available. Energy efficiency and fuel choice are small parts of the considerations of the designer, builder, or consumer in selecting building equipment and appliances. 


\section{policy/regulatory}

- Restructuring of the natural gas utility industry may result in a significant reduction in research for efficiency improvements. Large gas companies are becoming more service oriented and no longer depend on research and improved, more efficient equipment as their marketing tools or source of income.

- Expiration of "oil-overcharge" funds will further reduce funding available for the procurement of higher efficiency building equipment and products.

\section{environment}

- Tighter emission limits on localized point sources (e.g., individual buildings) could hamper the deployment of natural gasfired building equipment technologies.
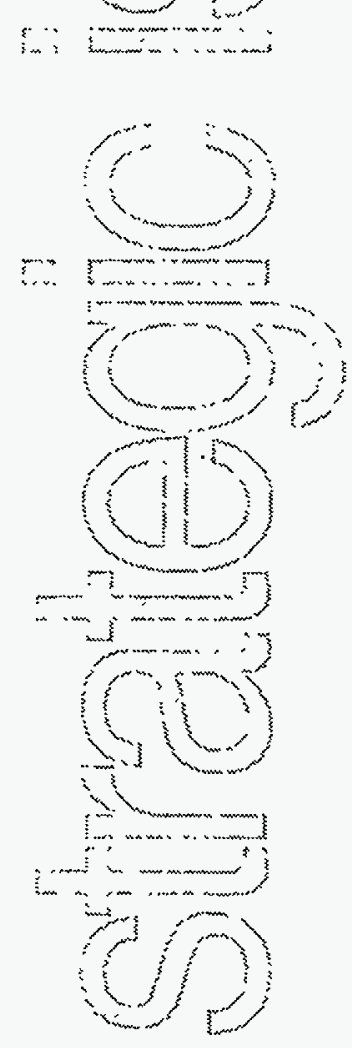


\section{- program goals and strategies}

The overall goal of DOE's Residential and Commercial program is to improve the energy efficiency of building equipment and appliances, thereby reducing annual building sector energy use by two quadrillion Btu from today's level of consumption by the year 2010. DOE's natural gas program addresses this goal while simultaneously reducing peak electricity demand and greenhouse gas emissions, eliminating the use of ozone-depleting chemicals in building equipment, and improving indoor air quality.

\section{technology}

Goal: Increase the energy performance of natural gas-fired building heating and cooling technologies.

\section{Strategies:}

- Introduce a gas-fired absorption (GAX) heat pump with a Coefficient of Performance (COP) of 1.7 or better to the residential market by 1997 .

- Introduce a gas-fired advanced cycle absorption chiller with a cooling COP of 1.4 or better into the commercial market by 1997.

- Develop residential absorption heat pumps and large commercial chillers using advanced "Hi-Cool" technology which has a residential cooling COP of 1.0 (2.0 for commercial chillers), and uses advanced fluids and improved cycles.

- Develop and demonstrate small [25-250 kilowatt (kW)] fuel cell cogeneration systems for use in commercial and multifamily buildings by the year 2000 .

- Support the development and commercialization of a new generation of desiccant cooling and dehumidification, domestic water heating, and commercial appliance technologies, all of which operate at high levels of energy efficiency using natural gas. 


\section{market}

\section{Goal: Promote the commercial} introduction of American-manufactured natural gas-driven equipment and appliance technology, both within the U.S. and in international markets.

Strategies:

- Form partnerships with industry and natural gas utilities to cost-share the refinement of several high efficiency gas technologies and bring them to the building marketplace.

- Assist the natural gas industry in developing and disseminating information about advanced natural gasdriven building equipment and appliances.

\section{policy/regulation}

Goal: Reduce regulatory, market, and technical obstacles to the utilization of natural gas within residential and commercial buildings.

Strategies:

- Articulate and promote DOE's position to Federal, State, and local regulatory bodies affecting natural gas utilization within residential and commercial buildings.
- Work with State and local code officials and other decisionmakers to ensure that Federal, State and local policies affecting natural gas utilization within residential and commercial buildings are complementary.

- Assist in the implementation of policy changes to remove impediments to expanding the natural gas delivery infrastructure to serve the Nation's buildings population.

\section{environment}

Goal: Maximize the environmental benefits resulting from the efficient use of natural gas in residential and commercial buildings.

\section{Strategies:}

- Assist equipment manufacturers in the development of natural gas-fired heating and cooling technologies that do not require the use of ozone-depleting chemical refrigerants.

- Assist the natural gas and electric utility industries in developing and disseminating information on the environmental benefits associated with the use of building-sited fuel cell cogeneration technologies as supplements to central station electricity generation. 


\section{performance indicators}

- Success of currently ongoing joint DOE/industry development of the GAX heat pump and triple-effect commercial chiller. (Near-Term)

- Level of industry and utility participation in DOE Technology Introduction Partnerships program and other product commercialization efforts. (Near-Term)

- Reduction in emissions of $\mathrm{CO}_{2}$ and other environmental pollutants by over 60 percent in new high efficiency natural gas-fired heating and cooling equipment starting in 1998. (Near-Term)

- Elimination of the use of chlorofluorocarbon (CFC) and hydrochlorofluorocarbon (HCFC) refrigerants by introducing natural gas-fired absorption systems into the marketplace by 1998 . (Near-Term)

- Substantial reduction in the electric load peaking problem experienced by the electric utilities during peak summer cooling periods. (Mid-Term)

- Performance of new technologies under development for domestic water heating, desiccant dehumidification, and commercial appliances. (Mid- to Long-Term)

- Increase in market share of small-scale fuel cells utilized as building cogeneration systems. (Mid- to Long-Term)

- Reduction in primary energy use for space conditioning and water heating by 4 quadrillion Btu by the year 2020. (Long-Term) 
6-14 


\section{m program overview}

program activities summary

The Department's program for enhancing the utilization of natural gas within the buildings sector is organized into five primary activities. An example is the GAX heat pump. This technology is twice as efficient as gas furnaces meeting the National Appliance Energy Conservation Act (NAECA) of 1987 minimum efficiency standards, and more than 70 percent better than the current highest efficiency furnaces. Gas-fired absorption heat pumps will eliminate ozone depleting CFC and HCFC refrigerants and reduce electric utility summer peak loads. Coordinated application of the GAX heat pump with engine waste heat or fuel cell waste heat for cogeneration and electric production applications can improve overall system efficiency by 50 percent or more.

Another example is the gas-fired advanced cycle absorption chiller, which is $30-50$ percent more efficient than the equivalent Japanese double-effect absorption chillers, and considerably less costly. This chiller will also reduce electric utility peak loads and eliminate CFC and HCFC refrigerants. Combining this technology with desiccant dehumidification and waste heat from fuel cells for electric production can significantly improve the overall energy performance of chillers. A summary of these activities follows:

- Advanced Heating and Cooling: This program is currently supporting the development and commercialization of several advanced (absorption cycle) gas-fired heat pump and refrigeration systems. These systems are over twice as energy-efficient as electricity-driven heat pumps and commercial chillers, and do not require the use of ozone-depleting chemical refrigerants.

- Desiccant Dehumidification and Cooling: This program is developing new desiccants capable of efficiently and economically removing moisture from building air as a means of improving the energy efficiency of cooling and refrigeration systems. A new generation of solid and liquid desiccants is being developed and integrated into packaged systems in cooperation with major manufacturers and utilities.

- Fuel Cell Microcogeneration: The focus of this program is on the development and commercialization, in cooperation with the natural gas industry and major manufacturers, of small-scale fuel cell power plants capable of producing on-site electricity and thermal energy for use within buildings. Initial efforts are being directed at the small commercial market (25-250 kW), with longer-term development targeted at large single and mulifiamily units in the $3-5 \mathrm{~kW}$ range. 
- Gas-Fired Building Appliances: This program is developing new methods to more efficiently apply natural gas as an energy source for domestic water heating, household refrigeration/freezing, and cooking applications. Research is being carried out on both incremental improvements to existing combustion technology for water heating and cooking, as well as on advanced thermodynamic cycles (e.g., adsorption, Stirling, thermoelectric) for water heating and household refrigeration applications.

- Market Commercialization: DOE is carrying out its Technology Introduction Partnerships program and additional efforts to improve the market acceptance of existing but underutilized building equipment and appliances. These industry collaborative efforts, conducted under Sections 127 and 128 of EPACT and the Administration's Climate Change Action Plan, will serve to accelerate the commercial availability and widespread adoption of highly efficient natural gas equipment and appliance technologies within residential and commercial buildings.

\section{changes from previous plan}

The FY 1994 Natural Gas Strategic Plan and Multi-Year Crosscut Program Plan did not aggregate building technologies under a single section. Rather, building technologies were distributed within various subsections of the Utilization Area section. The previous Plan also did not include explicit consideration for desiccant technology and advanced appliances.

\section{FY 1994-1996 budget summary}

(Dollars in Million)

\begin{tabular}{|l|c|c|c|}
\hline DOE Office & $\begin{array}{c}\text { FY 1994 } \\
\text { Actual }\end{array}$ & $\begin{array}{c}\text { FY 1995 } \\
\text { Approps }\end{array}$ & $\begin{array}{c}\text { FY 1996 } \\
\text { Request }\end{array}$ \\
\hline Energy Efficiency & 7.3 & 8.8 & 8.8 \\
\hline Total DOE & 7.3 & 8.8 & 8.8 \\
\hline
\end{tabular}

'Appropriation 


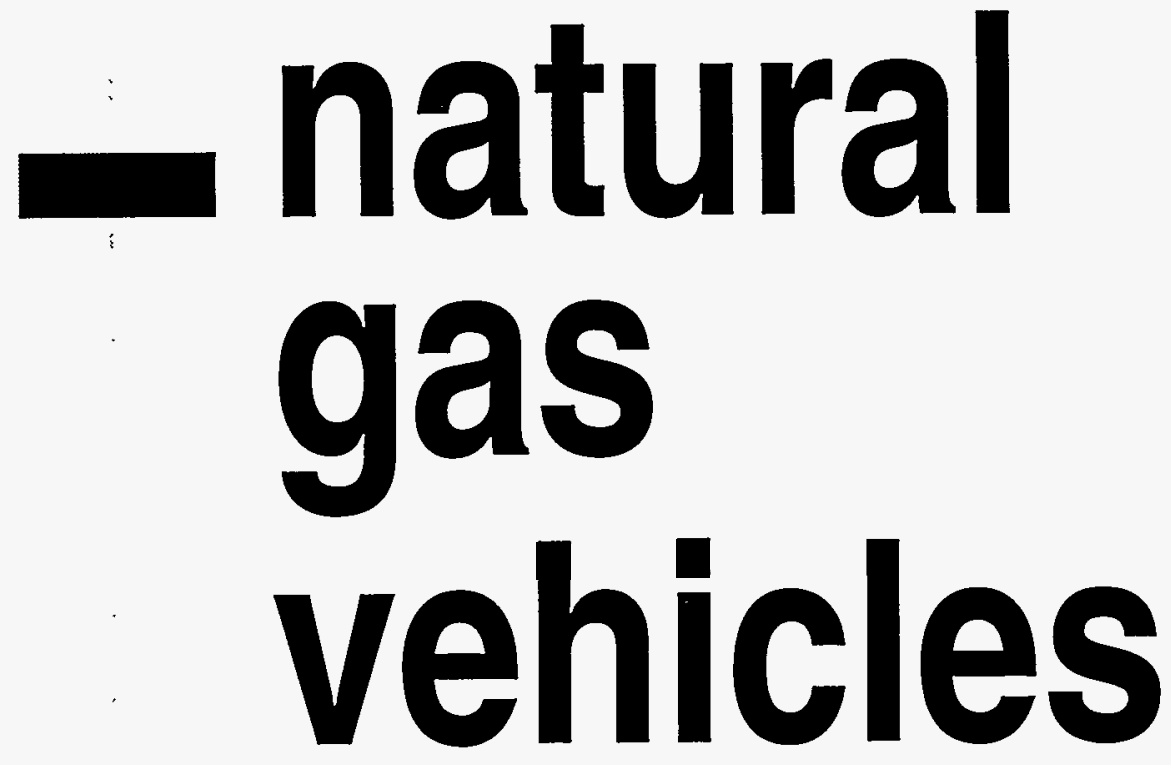





\section{Page No.}

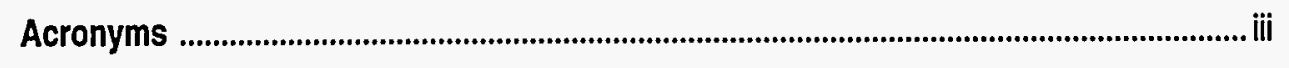

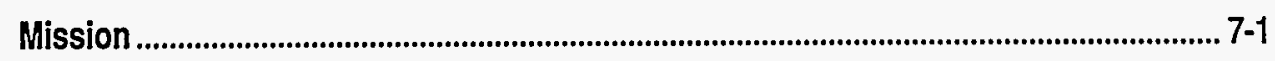

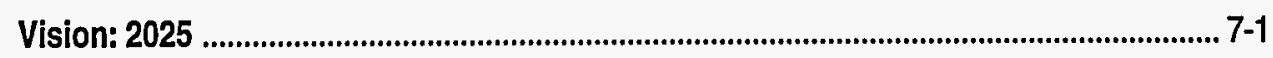

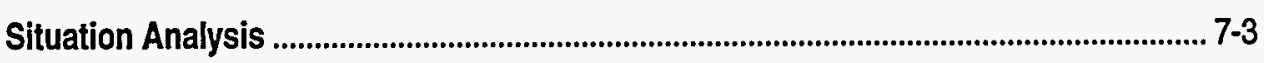

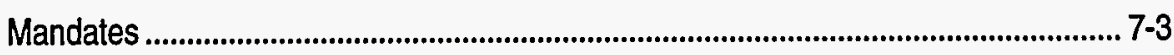

Program Relationships ......................................................................................

Current Situation .............................................................................................

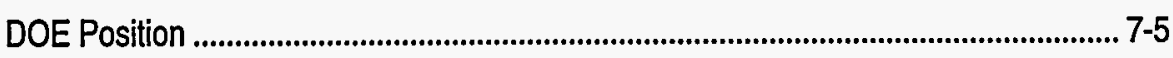

Stakeholder Considerations ............................................................................... 7-5

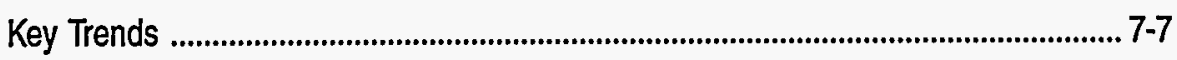

Key Planning Assumptions ................................................................................ 7-8

Strategic Issues ................................................................................................................. 7-11

Program Goals and Strategies ...................................................................................... 7-13

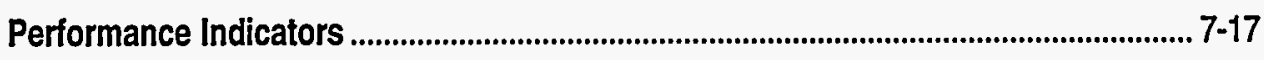

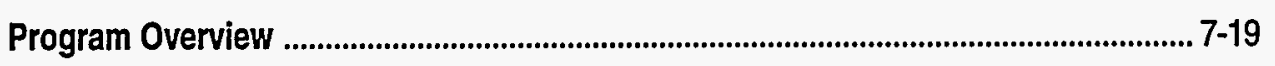

Program Activities Summary ............................................................................. 7-19

Changes from Previous Plan ............................................................................. (7-20

FY 1994-1996 Budget Summary ................................................................................. 7-20 


\section{acronyms}

AFV Alternative Fuel Vehicle

CAAA Clean Air Act Amendments of 1990

CNG Compressed Natural Gas

DOE Department of Energy

EPACT Energy Policy Act of 1992

FY Fiscal Year

GRI Gas Research Institute

GSA General Services Administration

ILEV Inherently Low Emission Vehicle

kW Kilowatt

LNG Liquefied Natural Gas

LPG Liquefied Petroleum Gas

NGV Natural Gas Vehicle

$\mathrm{NO}_{\mathrm{x}} \quad$ Nitrogen Oxides

OEM Original Equipment Manufacturer

OTT Office of Transportation Technologies

SLIP State and Local Incentives Program

$\mathrm{SO}_{\mathrm{x}} \quad$ Sulfur Oxides

ULEV Uitra-Low Emission Vehicle 
ביב 


\section{mission}

DOE's Natural Gas Vehicles program, in partnership with the transportation vehicle manufacturing industry and the natural gas industry, undertakes and promotes activities that will lead to the production and utilization of natural gas vehicles in a manner that satisfies the consumers' needs, efficiently utilizes domestic natural gas and displaces petroleum imports, leads to a significantly improved atmospheric environment, and encourages domestic economic growth and job creation.

\section{vision: 2025}

Vehicles using natural gas as their base source of fuel are commonplace for all modes of ground transportation including cars, light- and heavy-duty trucks, buses, and locomotives. Natural gas has displaced 15 percent of petroleum for transportation use. Natural gas vehicles, and their related manufacturing, supply, and service organizations, are major contributors to the national economy. The efficient and clean use of natural gas is a major contributor to the much cleaner atmospheric environment, and to the reduction of greenhouse gases. The Nation is far less vulnerable to disruptions of the petroleum fuel supply. The U.S. exports natural gas vehicles (and supporting equipment and components) in significant quantities, and they are commonplace worldwide. 
7-2 


\section{- situation analysis}

\section{mandates}

Alternative Motor Fuels Act of 1988: Encourages development and widespread use of alcohols and natural gas as transportation fuels and manufacture of alternative fuel vehicles.

Clean Air Act Amendments of 1990 (CAAA): Calls for more stringent emissions for both light-duty and heavy-duty vehicles; establishes fleet mandates for light-duty and heavy-duty "clean fuel vehicles" (starting in 1998), which include those operating on alternative fuels, reformulated gasoline, and clean diesel.

Energy Policy Act of 1992 (EPACT): Includes provisions for increased use of alternative fuels and suggests goals for displacing motor fuel use of 10 percent by 2000 and 30 percent by 2010 , and requires acquisition of alternative fuel vehicles by fleets in accordance with a prescribed schedule.

Executive Orders 12759 and 12844: Call for energy efficiency improvements and alternative fuel utilization by the Federal government; allow the Federal government to serve in a leadership position in technology utilization, and provide a significant market impetus for the development and manufacture of alternative fuel vehicles and expansion of a fueling infrastructure.

Intermodal Surface Transportation Efficiency Act of 1991: Authorizes funds within the Congestion Mitigation and Air Quality Improvements Program that can be used by States to fund alternative fuel vehicle (AFV) activities (either vehicles or refueling facilities) if AFVs are needed to meet the CAAA requirements or are included in State implementation plans.

\section{program relationships}

The Natural Gas Vehicles program is one of many programs funded and managed by the Office of Transportation Technologies (OTT) of the Office of Energy Efficiency and Renewable Energy. Within DOE, the Office of Transportation Technologies has the overall responsibility for the development of all advanced transportation systems which use both conventional fuels and alternative fuels, including natural gas. OTT also has the responsibility for development of biofuels, including the agriculture systems and the fuel production and distribution systems. 
Essentially, all of the DOE natural gas vehicle program activities are funded and conducted as a part of similar activities being performed in conjunction with other fuels. This combination of activities is considered to be beneficial both from a management perspective, as well as the fact that similar activities benefit from the combination of resources and the application of available expertise. In addition, both activities will benefit from the learning that inevitably results from combined broad-based research and development efforts.

The Office of Transportation Technologies makes extensive use of DOE's National Laboratories, universities, and industrial partners, in pursuit of natural gas vehicle program goals. Program activities include applied research, technology development, vehicle and systems demonstrations, vehicle deployment support, data collection, information dissemination, and program management support. The major laboratories participating in OTT natural gas activities include the National Renewable Energy Laboratory, Oak Ridge National Laboratory, Argonne National Laboratory, Brookhaven National Laboratory, and the Johns Hopkins University's Applied Physics Laboratory.
Special emphasis is placed on coordinating the DOE Natural Gas Vehicles program with other programs sponsored by the natural gas industry, especially those of the Gas Research Institute (GRI). Part of this activity has become formalized with the signing of the Memorandum of Understanding between the DOE and GRI on May 20, 1994.

\section{current situation}

There is a rapidly growing demand for transportation services in the United States. The number of vehicle miles traveled in the U.S. increased from approximately one trillion miles in 1970 to two trillion miles in 1990 and this growth is expected to continue.

The transportation sector now depends almost entirely (over 96 percent) on petroleum. Transportation currently consumes approximately 11 million barrels per day of petroleum fuel, which exceeds domestic oil production by about 50 percent. Transportation fuel usage is equivalent to approximately 22.8 trillion cubic feet of natural gas per year, however, only 0.02 percent of the fuel consumed is natural gas.

Few viable alternatives, such as natural gas, are currently being utilized. Of the 182 million automobiles and trucks in use in the U.S. in 1992, only about 50,000 of these vehicles were fueled by natural gas. Currently, there are more than 700 natural gas refueling stations in the U.S. Approximately half of these stations are accessible to the public. New stations are being opened at the rate of about three or 
four per week. Natural gas now has a slight fuel cost advantage over petroleum fuels in most regions and a significant cost advantage over other alternative fuels.

The current program, to develop and utilize alternative fuels for transportation, is primarily directed at displacing petroleum fuels and reducing harmful air pollutants and greenhouse gases from the transportation sector. Transportation remains a major contributor to atmospheric pollution in the U.S., even though large improvements have been made in the past decade. Natural gas use in transportation vehicles would result in no emissions of lead, particulates, or evaporative emissions; there would also be major reductions in most other key pollutants (especially non-methane hydrocarbons and carbon monoxide).

\section{DOE position}

DOE is committed to the development and commercialization of transportation vehicles, engines, fuels, and integrated systems that will efficiently utilize alternative fuels in an economically competitive and environmentally clean manner. A number of fuels are currently being investigated and promoted as promising candidates, including natural gas, methanol, ethanol, propane, and electricity. At the present time, OTT is practicing a "uuel neutrality" policy, by not identifying any fuel as the preferred fuel; however, it must be noted that OTT considers compressed natural gas (CNG) as a very promising alternative fuel in terms of costcompetitiveness, domestic sources, vehicle performance, and potentially low emissions.

Programs are being funded to evaluate the thermal, economic, and environmental emissions performance of natural gas in both light-duty and heavy-duty vehicles.

DOE programs recognize the position that the successiul evolution of natural gas as a transportation fuel cannot be achieved through Federal actions alone; instead, there must be an integrated and focused effort that utilizes the combined cooperative resources of the principal participants including the natural gas industry, the transportation manufacturing industry, consumers, and the regulators.

\section{stakeholder considerations}

There is a wide variety of organizations which have significant stakes in the development and commercialization of natural gas vehicles (NGVs). These include both private industry and government, at a number of levels. The major concerns and considerations for each of these stakeholder groups are summarized below:

Congress: Some of the issues that are debated in the Congress include whether the Nation should pursue a "fuel neutral" or a "fuel specific" approach; net benefits of displacing imported petroleum to the Nation; potential burdens on the U.S. auto industry 


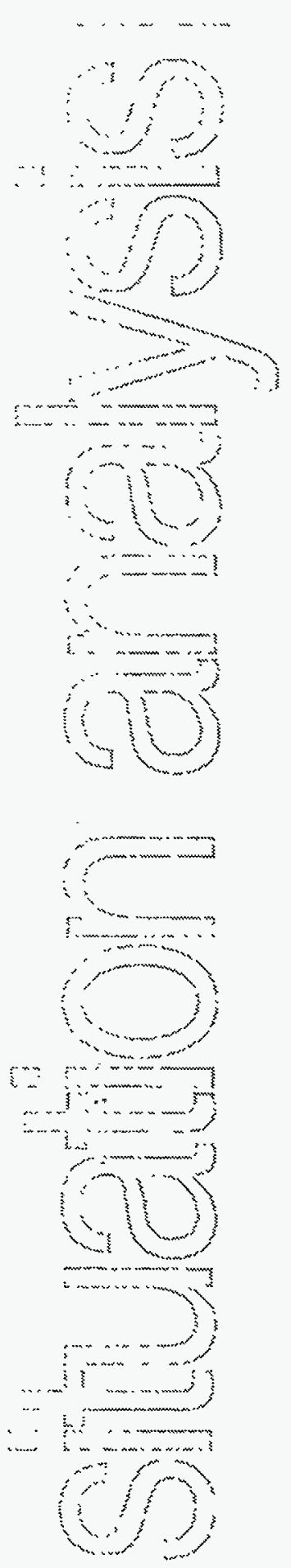

as a result of a mass transition to NGVs; and the net impact on domestic employment.

State and Local Governments: Interests of this group include incremental purchase costs for fleet NGVs; reduced model availability from original equipment manufacturers (OEMs); vehicle range and utility; uncertain availability of infrastructure (especially refueling); and Federal air quality mandates.

\section{Local Distribution Companies (Gas} Utilities): Local distribution companies are concemed with cost issues (e.g., cost of fueling station equipment to provide gas composition specified by engine and vehicle manufacturers, and cost to build adequate infrastructure); public utility commissions' views towards ratebasing or approving natural gas vehicle or infrastructure research and development or marketing investments; availability of natural gas vehicles (e.g., the commitment of engine and vehicle manufacturers); and investment payback periods.

\section{Engine and Vehicle Manufacturers:} Manufacturers of NGVs are uncertain as to the size of the market for NGVs and, prior to making sizable investments, they need to determine whether NGVs will be niche or mass market. There is also uncertainty regarding the availability of the required infrastructure (especially refueling). Other interests and concerns include the impact of NGVs on existing gasoline and diesel products; long-term stability of natural gas prices; market projections for potential buyers; liability for NGV accidents; costs of building NGVs versus the profitability in selling them (i.e., whether potential customers would be willing to pay for the higher incremental cost); and unclearl uncertain regulatory requirements.

\section{Equipment Suppliers: Concerns of this} group include length of time required for the market to materialize to a significant level; sizable capital investments required versus uncertain payback; and future sales that are intimately linked to OEM decisions.

Fuel Retailers: Fuel retailers are concerned with costs per station for equipment, installation, and operation; low throughput of NGV refueling stations versus those for petroleum; length of time required for the market to materialize at a significant level; and strict and sometimes onerous building and fire code interpretation, making compliance difficult.

End Users: End users are concerned with costs associated with changing fuel selection, including both vehicle incremental costs and fueling station costs (where applicable); vehicle range and utility; stability of natural gas prices; uncertain availability of infrastructure (especially refueling); existence of OEM warranties; NGV safety, compared to that for gasoline or diesel vehicles; and resale value, especially for fleets. 
Natural Gas Industry: Concerns of the natural gas industry include motivation and commitment of OEMs; investments required versus projected natural gas sales; and regulatory uncertainties.

Insurance/Safety Organizations: These organizations are interested in information regarding operations and safety of NGVs.

\section{key trends}

\section{technology}

- Transportation vehicles using petroleumbased fuels (e.g., gasoline and diesel) have become very well entrenched during the past several generations, and are strong competitors to the introduction of all alternative fuels.

- Petroleum-based transportation engines and vehicles are continuing to improve in quality, performance, and emissions, thereby providing increasing competition to all alternative fuels, including natural gas.

- Development of other alternative fuels for transportation (especially methanol, ethanol, propane, and electricity) will continue to progress, thereby intensifying competition for natural gas within the alternative fuel vehicle market.

\section{market}

- Improvements in NGV fuel storage tanks and vehicle designs are expected to provide safe storage of sufficient quantities of fuel to provide for vehicle ranges that are compatible with users' requirements and thereby eliminate one of the major impediments to expanded market penetration of NGVs.

\section{policy/regulatory}

- Recent Federal and State initiatives have accelerated the development of the NGV market (e.g., CAAA established stringent emission standards for fleet operators), which will help in reducing the current cost gap between NGVs and gasoline vehicles; EPACT requires fleets to purchase alternative fuel vehicles (AFVs); Federal government NGV purchases and conversions have increased (as of January 1993, nearly 90 percent of AFVs were fueled by CNG); and California, Texas, and New York have led implementation of comprehensive State alternative transportation fuel and vehicle programs.

\section{environment}

- Emission regulations and requirements are expected to place increasing emphasis on reducing nitrogen oxides $\left(\mathrm{NO}_{\mathrm{x}}\right)$, sulfur oxides $\left(\mathrm{SO}_{\mathrm{x}}\right)$, and unburned hydrocarbons, which will enhance competitive advantages of natural gas. 


\section{key planning assumptions}

\section{technology}

- Current performance shortcomings of NGVs (especially vehicle range) will diminish over the next decade.

- Dual-fuel NGVs will disappear as the natural gas distribution and vehicle infrastructure develops.

\section{market}

- Incremental purchase cost of NGVs will decrease, but will not become negligible.

- Incremental operating cost benefits will remain positive for most natural gas vehicle fleet operators, even though some of the existing advantages such as introductory deals (on fuel prices and refueling equipment) will end as NGVs become more common.

- The issue of competitive prices will intensify as NGVs achieve substantial market penetration.

- Overall life-cycle costs of NGVs will remain comparable to those of conventionally fueled vehicles.

\section{policy/regulatory}

- Federal government efforts will continue to overcome obstacles to AFVs by, among other things, placing them in the Federal fleet and coordinating efforts with those of State, local, and private entities for development of a self-sustaining alternative fuel infrastructure.

- Increased number of State and local governments will consider and implement alternative transportation fuel programs and incentives, primarily to help meet clean air standards promulgated in CAAA (e.g., fuel excise and sales tax exemptions; investment tax credits; community grant programs; vehicle conversion rebates; fuel use mandates for State-owned or leased vehicles; research and development funding; and in the case of compressed natural gas, deregulation of end-user sales).

\section{environment}

- Increasingly stringent environmental requirements will help to accelerate market penetration of NGVs due to their potential for significantly lower emissions. 
- Some NGV models will be

commercially available and will be classified as Ultra-Low Emission

Vehicles (ULEV) or Inherently Low

Emission Vehicles (ILEV).

- Original equipment manufacturer vehicles are expected to capture increasing shares of the NGV market due to their lower emissions, and their achievement of higher performance when compared to conversion vehicles. 



\section{strategic issues}

\section{technology}

- Lower energy density of natural gas requires additional fuel storage space and thereby reduces vehicle cargo space.

\section{market}

- Mass-produced natural gas engines and vehicles are not now available for use by consumers in sufficient quantities to allow significant displacement of imported petroleum-based fuels.

- The use of petroleum as a transportation fuel has become a "habit" for many generations and it will be very difficult to change.

- Although there may be a small fuel cost advantage of natural gas over petroleum fuels, it may not be sufficient to cause a major "changeover" by significant number of buyers, especially due to incremental purchase costs and a developing infrastructure.

- Natural gas vehicle purchase costs will remain significantly higher than conventional, mass-produced vehicles until after NGVs reach significant enough production levels to achieve economies of scale, both at the vehicle and component levels.

- Natural gas vehicle manufacturers and users still lack confidence that natural gas will be available at conveniently located refueling stations in sufficient quantities and at competitive prices. The issue of competitive prices is expected to intensify as NGVs achieve substantial market penetration.

- The establishment of a widespread, publicly accessible refueling infrastructure remains to be achieved and will require major capital investment with some substantial risks. It will be difficult to convince investors of sufficient demand to warrant building the infrastructure until NGVs are available and operating in significant numbers.

- Consumers will be hesitant to purchase NGVs until a widely available service and parts infrastructure exists.

- Relatively limited experience in the U.S. with natural gas as a transportation fuel has created a number of educational and informational gaps, such as local safety officials that do not completely understand CNG technologies (especially for refueling stations), lack of certification programs (for fuel system equipment, vehicle converters, and conversions), and training programs (for repair technicians and operators). 


\section{policy/regulatory}

- Strategic partnerships among the natural gas industry, fuel retailers, fleet owners, vehicle and component manufacturers, and Federal and State governments are needed to develop successful NGV technology and products that meet the needs of the consumers and to deploy NGVs on a sustainable basis.
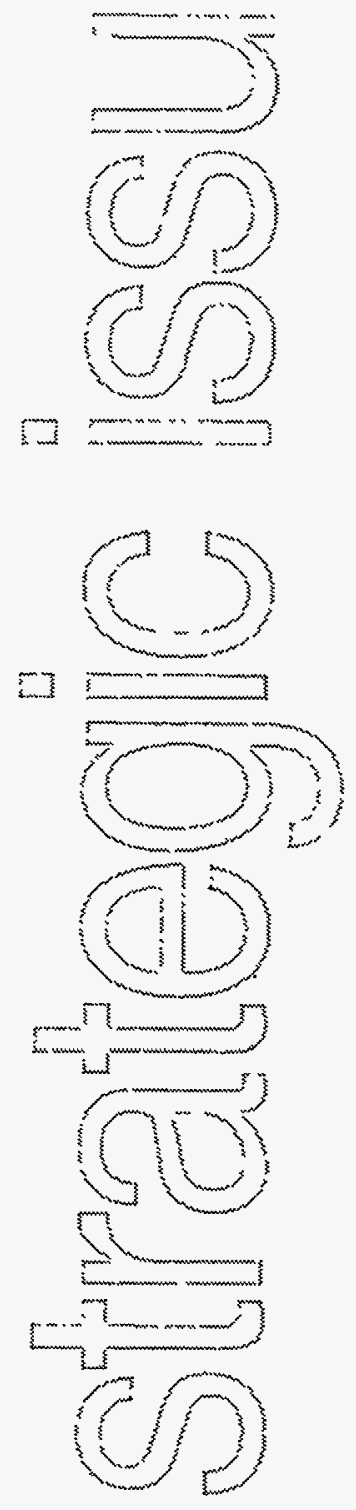


\section{program goals and strategies}

\section{technology}

Goal: Acquire information from natural gas vehicle testing under field use conditions to establish or confirm their anticipated performance.

Strategies:

- Operate selected light-duty vehicles in Federal fleets, mass transit buses, and heavy-duty trucks to acquire data on performance and emissions of alternative fuels (as required by the Alternative Motor Fuels Act).

- Conduct similar fleet test operations on school buses, municipal vehicles, military motor pool fleets, and selected special commercial fleets.

- Report findings on comparative analyses of fuels and alternative fuel vehicles.

- Store data at the DOE Alternative Fuel Data Center so that it can be accessed by manufacturers, operators, decisionmakers, and other interested parties.

Goal: Develop engines, vehicles, and systems in the light- and heavy-duty classes which have performance and economics comparable to similar petroleum-based fuels.

Strategies:

- Establish, implement, and maintain working agreements with the natural gas industry, and engine, transportation vehicle, and equipment manufacturers.

- Develop dedicated (single fuel) natural gas engines and vehicles having performance and emissions superior to gasoline or diesel fuel-powered engines and vehicles.

- Evaluate feasibility of high-efficiency liquefied natural gas (LNG) locomotive engine.

- Develop CNG absorbents to decrease storage tank weight and increase vehicle range.

- Develop conformable CNG tanks and advanced vehicle designs to increase on-board fuel storage capacity.

- Adapt existing popular model heavy-duty engines to dedicated natural gas or dual-fuel operation. 
Goal: Develop fuel cells that can be reliably and cost-effectively used for both light-duty and heavy-duty transportation systems, and use fuels derived from natural gas (such as methanol) to achieve extremely low atmospheric emissions.

\section{Strategies:}

- Use cost-sharing contracts to team with industrial participants.

- Continue research and development to develop and evaluate fuel cell component materials that are compatible with the electrochemical reactions, amenable to mass production manufacturing, and capable of enduring the rigorous environment of transportation vehicles.

- Continue into the Phase II development and demonstration of a 60 -kilowatt (kW) brassboard power system (30-kW proton exchange membrane fuel cell) suitable for automotive propulsion; build upon the success of the 10-kW fuel cell developed during Phase $I$.

- Develop advanced reformer and hydrogen storage technology which is critical to the successful application of fuel cells in transportation systems.

- Develop, build, and evaluate full scale urban transit buses powered by $50-\mathrm{kW}$ phosphoric acid fuel cells.
- Develop conceptual design and evaluate the technical feasibility and cost-effectiveness of a fuel cellpowered locomotive.

\section{market}

Goal: Increase market penetration of alternative fuel vehicles (including natural gas vehicles); initially, this goal will be focused on the displacement of fleet vehicles by AFVs that will include a significant proportion of natural gas vehicles.

\section{Strategies:}

- Provide incremental funding for AFV acquisition by Federal fleet, either OEM [via General Services Administration (GSA)] or certified retrofit of agencyowned vehicles.

- Coordinate GSAlagency assignments of AFVs including natural gas vehicles to maximize or leverage potential value to the Clean Cities Program.

- Promulgate rulemakings on alternative fuel providers, and on State, municipal, and private fleet alternative fuel vehicle acquisition schedules.

- Initiate State and Local Incentives Program (SLIP) to provide grants to selected States to implement alternative fuel vehicle programs.

- Develop certification methodology for AFV technicians training curricula. 
Goal: Conduct a vigorous information outreach activity that will provide consumers with information that will enable them to make informed purchasing decisions.

\section{Strategies:}

- Continue the Clean Cities Program to actively promote, support, and encourage the coordination of efforts by consumers, regulators, fuel suppliers, fleet operators, environmental groups, support services, and State and local governments.

- Continue the operation of the Alternative Fuels Data Center, a computerized database of information that can be accessed and searched electronically for desired natural gas vehicle information and data by all interested parties.

- Continue the operation of the National Alternative Fuels Hotline (800-4231DOE) which can be readily accessed for all available information on alternative fuels including natural gas, and for all sectors of the U.S. and international community.

- Implement a public information program to provide key information on alternative fuels, alternative fuel vehicles, and the current DOE programs.

- Conduct NGV-liquefied petroleum gas (LPG) student challenges to encourage engineering graduates to enter the AFV field.

\section{policy/regulatory}

\section{Goal: Support removal of policy and} regulatory barriers that impede and/or prevent natural gas vehicles from competing with other fuels and vehicles.

Strategies:

- Identify and analyze policy and regulatory barriers to widespread utilization of natural gas vehicles and expansion of refueling infrastructure.

- Work collaboratively with NGV manufacturers, the natural gas industry, regulators, and consumer groups to develop and implement initiatives for removal of identified barriers.

\section{environment}

Goal: Develop and operate natural gas vehicles which will contribute to the reduction of energy-related emissions of greenhouse gases to below 1990 levels by the year 2000.

Strategies:

- Provide the necessary Federal assistance for natural gas vehicle technologies to be developed and demonstrated so that NGVs can meet or exceed the emission criteria established by State or Federal laws and regulations. 
- The results from research and development work already completed have established the basic concepts and operating conditions that now must be incorporated into natural gas engines to meet emission requirements. Incorporate these basic concepts into mass producible engines and commercial vehicles to attain the potential advantages of the known emission reduction technologies.

- Conduct further research and development to reduce the total hydrocarbons and $\mathrm{NO}_{x}$ to meet emission goals.

- Utilize Federal resources to strongly promote and encourage widespread use of NGVs in large numbers so that the potential benefits of a cleaner environment can be realized in the near-term.
- Continue experiments to characterize emission signatures over the entire span of regulated emission compounds.

- Conduct specifically focused research to identify key hydrocarbon compounds which trigger smog-forming photochemical reactions.

- Develop computer models to predict urban smog production for air quality impacts.

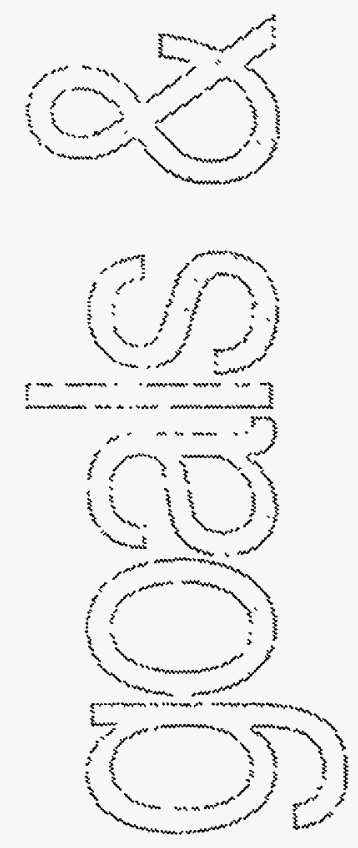




\section{performance indicators}

\section{technology}

- Success will be measured in terms of the completeness of the range of performance, reliability, safety, and economic comparative data that has been acquired, analyzed, and made readily available to all interested parties through the services of the DOE Alternative Fuel Data Center and the National Alternative Fuels Hotline.

\section{market}

- Initial market penetration in terms of the percentage of vehicles that have been introduced into the fleets relative to the percentage specified as DOE's goals.

- Success of the information outreach activity will be measured in terms of the number of municipalities designated as Clean Cities and the number of user inquiries that have been satisfactorily answered by the National Alternative Fuels Hotline.

\section{policy/regulatory}

- The number of policy and regulatory barriers removed and their contribution to increased utilization of natural gas vehicles.

\section{environment}

- The successful achievement of the legislated emissions levels in accordance with the specified schedule for the applicable classes of vehicles (measured and confirmed through the acquisition and analysis of test data from a statistically valid sample of commercially available vehicles operating in representative modes by consumers).

- Conduct of specifically focused research to identify key hydrocarbon compounds which trigger smog-forming photochemical reactions.

- Development of computer models to predict urban smog production for air quality impacts. 



\section{program overview}

\section{program activities summary}

The Department's Natural Gas Vehicles program activities are funded and managed by the Office of Transportation Technologies. The program is divided into the following five major elements: Vehicle Deployment, Data Acquisition, Engine Optimization, Atmospheric Reactions, and Fuel Cell Development. The activities are coordinated with the efforts of the natural gas industry to avoid duplication and to assure that the effort has an overall positive net benefit.

The research and development effort is performed almost exclusively by domestic industries, universities, and the National Laboratories that are also major participants in the overall management of the natural gas programs. Substantial resources are being focused on data collection regarding the performance, exhaust emissions, and economics of both light-duty and heavy-duty natural gas vehicles. This information is also being given widespread distribution throughout the Nation to increase the public awareness of the potential of natural gas vehicles.

Research and development on fuel cells for transportation is continuing to be given major portions of the available funding and is expected to yield significant mid- and long-term benefits. The two principal benefits of fuel cells are their extremely low emissions, and their potentially very high energy conversion efficiency. Near-term efforts will be focused on tests and evaluations of integrated fuel cell systems, the development of reformers to convert methanol into hydrogen as the major reactant for the fuel cell, and the development of advanced materials and components that will endure the internal conditions of the fuel cells and withstand the physical environment induced by the transportation vehicle. In-service reliability and life cycle costs also will be addressed in future efforts on fuel cells.

The Clean Cities Program: This is a Federally endorsed, volunteer program which actively promotes, supports, and encourages the coordination of efforts by consumers, regulators, fuel suppliers, fleet operators, environmental groups, support services, and State and local governments. The program purposes include exchanging information and viewpoints aimed toward achieving a commitment to attain the goals of increased use of AFVs, establishment or expansion of the AFV infrastructure, and stimulating the domestic fuels industry. The Clean Cities program has become operational and has exceeded its goals for the first year. Emphasis on this program will continue as an integral part of the natural gas vehicle strategy and increasing the public awareness. Substantial emphasis continues to be focused on the Federal government providing incremental funds for the procurement of alternative fuel vehicles (including a high percentage of natural gas vehicles). This includes both Federal fleet vehicles and other demonsiration vehicles such as school buses and municipal heavy-duty vehicles. In conjunction with this, data is collected from the use of these vehicles (plus non-Federally procured transit buses and commercial trucks) operating under real field test conditions. 


\section{changes from previous plan}

There has been a substantial increase in the resources directed at accelerating the development of fuel cells for transportation applications, which is demonstrated by the substantial budget growth in this area. Emission goals have become very specific, and their importance has been emphasized by the inclusion of these goals in Federal legislation. Provisions of the Energy Policy
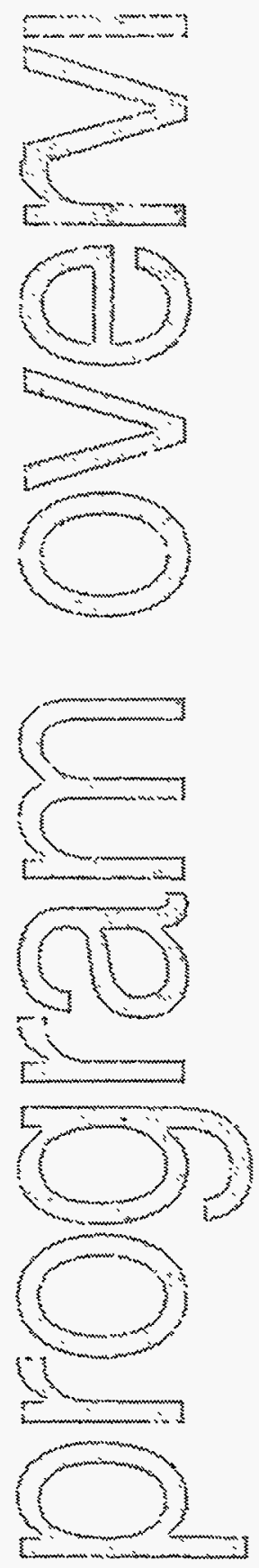

Act of 1992 have been reflected in the natural gas strategy, especially with regard to the establishment of mandates for including alternative fuel vehicles (e.g., natural gas vehicles) in Federal, State, alternative fuel supplier, and local and private fleets.

\section{FY 1994-1996 budget summary}

(Dollars in Million)

\begin{tabular}{|c|c|c|c|}
\hline DOE Office : & $\begin{array}{l}\text { FY } 1994 \\
\text { Actual : }\end{array}$ & $\begin{array}{l}\text { FY } 1995 \\
\text { Approp. }\end{array}$ & $\begin{array}{l}\text { FY } 1996 \\
\text { Request }\end{array}$ \\
\hline Energy Efficiency & 27.8 & 33.4 & 47.8 \\
\hline Total DOE & 27.8 & 33.4 & 47.8 \\
\hline
\end{tabular}

${ }^{1}$ Appropriation 


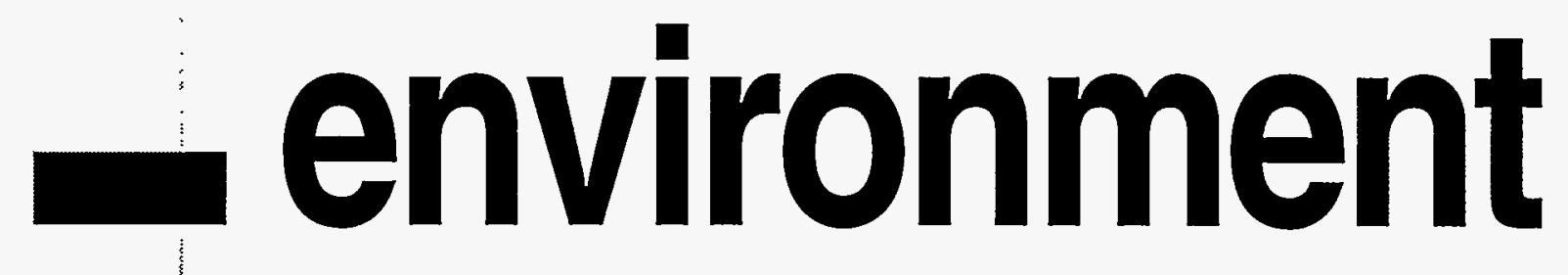



Page No.

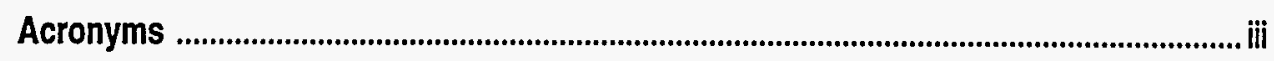

Mission ............................................................................................................................................ 8-1

Vision: 2025 ...............................................................................................................

Situation Analysis ..............................................................................................................

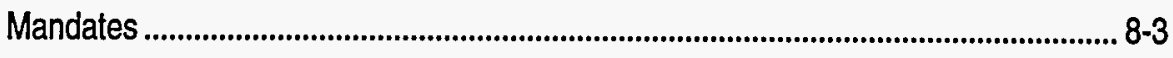

Program Relationships .................................................................................................... 8-3

Current Situation ................................................................................................................ 8-4

DOE Position .................................................................................................................. 8-5

Stakeholder Considerations ............................................................................................. 8-6

Key Trends ..................................................................................................................... 8-8

Key Planning Assumptions ............................................................................................ 8-8

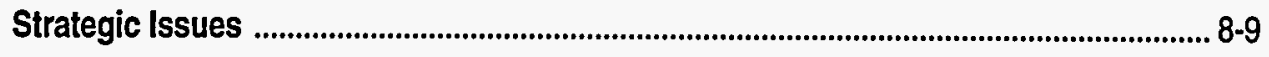

Program Goals and Strategies ......................................................................................... 8-11

Performance Indicators ........................................................................................................ 8-15

Program Overview .................................................................................................................. 8-17

Program Activities Summary ....................................................................................... 8-17

Changes from Previous Plan ......................................................................................... 8-18

FY 1994-1996 Budget Summary ................................................................................... 8-18 


\section{acronyms}

\begin{tabular}{ll} 
CAAA & Clean Air Act Amendments of 1990 \\
CFCs & Chlorofluorocarbon \\
CO & Carbon Monoxide \\
CO $_{2}$ & Carbon Dioxide \\
CRADA & Cooperative Research and Development Agreement \\
CWA & Clean Water Act \\
DOE & Department of Energy \\
DOI & Department of the Interior \\
EPA & U.S. Environmental Protection Agency \\
EPACT & Energy Policy Act of 1992 \\
GCCAP & Global Climate Change Action Plan \\
HCFC & Hydrochlorofluorocarbon \\
IRP & Integrated Resource Planning \\
SNG & Liquefied Natural Gas \\
SDWA & Safe Drinking Water Act of 1984 \\
NARSTO & North American Regional Strategy for Tropospheric Ozone \\
NORM & Naturally Occurring Radioactive Materials \\
NO & Nitrogen Oxides \\
NPC & National Petroleum Council \\
PUC & Public Utility Commission \\
\hline
\end{tabular}





\section{mission}

DOE's Environment program, in partnership with industry and stakeholders, undertakes activities to develop and promote advanced natural gas technologies that minimize the environmental impact of energy operations and emissions from energy use.

\section{vision: 2025}

Natural gas use has increased in all sectors and reached its potential to provide environmentally clean fuel and feedstock resources for the economic prosperity of the United States, and in improving the global environment. 



\section{mandates}

- Resource Conservation and Recovery Act (RCRA): Regulates drilling wastes, produced water, other exploration and production wastes, surface impoundments, and site remediation.

- Clean Water Act (CWA): Regulates produced water and drilling waste discharges onshore and offshore, as well as access to and operations in wetlands.

- Safe Drinking Water Act of 1984 (SDWA): Regulates underground injection of produced water for disposal or enhanced recovery.

- Clean Air Act Amendments of 1990 (CAAA): Regulates air emissions from exploration and production sites, pipelines, and end-user facilities. Increasingly stringent standards are being phased in for nitrogen oxides $\left(\mathrm{NO}_{\mathrm{x}}\right)$, sulfur dioxide $\left(\mathrm{SO}_{2}\right)$, carbon monoxide $(\mathrm{CO})$, and other emissions. Also encourages alternative fuels use in vehicles.

- Energy Policy Act of 1992 (EPACT): Encourages the use of natural gas in alternative fuel vehicles, and in electric generation by revisions of the Public Utility Holding Company Act. It also mandates utility Integrated Resource Planning (IRP) including natural gas applications, and requires that the U.S. Environmental Protection Agency (EPA) develop emissions standards and test procedures for alternative fuel vehicles, and evaluate the success of clean fuels programs in controlling air pollution.

\section{program relationships}

In recent years, industry and professional organizations have increased their efforts to assist individual companies to improve environmental performance and reduce environmental compliance and mitigation costs. DOE works cooperatively with these organizations to avoid duplication and to leverage resources. DOE, EPA, American Petroleum Institute, the Gas Research Institute, and others cosponsored Society of Petroleum Engineers conferences on environmental issues related to gas and oil exploration and production in 1993 and 1995. 
In addition, DOE works to improve scientific understanding of environmental risks associated with gas production, transmission, and use. By conducting studies to determine the impact of produced waters on the environment, for example, DOE helps regulatory officials at the Federal and State levels develop appropriate and effective regulations. EPA and the Department of the Interior (DOI) are the primary Federal agencies issuing environmental regulations affecting gas supply and use. EPA and DOE cooperate in areas of mutual interest, including: energy efficiency and conservation, pollution prevention, innovative regulatory approaches, technology transfer, and development of environmentally sound manufacturing technologies.

\section{current situation}

A major recommendation of the National Petroleum Council (NPC) study, The Potential for Natural Gas in the United States (1992) is that government at all levels should create a balance between costs and benefits in the legislative and regulatory process for environmental and resource access issues, including direct recognition of the environmental benefits of natural gas as a clean burning fuel. Environmental considerations pose both opportunities and challenges for natural gas, which is generally perceived as cleaner than other fossil fuels because of low $\mathrm{SO}_{2}$ and particulate emissions. A number of recent legislative and Administration policy initiatives provide the framework for DOE efforts in the area of environmental policy and research.

The CAAA remains a major driver for research on atmospheric emissions so that they can be better understood and controlled. Market prices of fuels frequently do not reflect the environmental benefits of their use, particularly for natural gas with respect to other fuels. As an example, requirements in the CAAA for decreasing automotive emissions according to Tier I and Tier II standards present opportunities for natural gas vehicles. Implementation of CAAA and recommendations from the National Academy of Sciences Report on Urban Ozone in 1991 may lead to further constraints on $\mathrm{NO}_{\mathrm{x}}$ emissions from mobile and stationary sources. Adoption of California air quality standards by other States will tighten emission standards even more rapidly than CAAA requirements.

Environmental impacts of energy operations remain an important area of interest. There is concern within the exploration and production sectors that increasingly stringent environmental regulations will significantly hinder gas production due to higher compliance costs, without commensurate environmental benefits. This concern, combined with continuing restrictions on access to potential production areas, could limit the amount of recoverable gas reserves in the United States. A number of Federal environmental statutes are scheduled to be reauthorized or to have new implementing 
regulations that increase the compliance costs or may restrict production activities.

Commitments made in the Montreal Protocol to phase out chlorofluorocarbons (CFCs) by the year 2000 could expand the use of gasfired absorption chillers, which do not contain CFC refrigerants. As evidenced by the international consensus reached at the Rio Summit in 1992, there is increasing international concern about the proliferation of greenhouse gases, which include $\mathrm{CO}_{2}$ and methane. DOE is quantifying the environmental and economic impacts of increasing greenhouse gases.

\section{DOE position}

The DOE mission will be achieved by:

(1) ensuring the availability of low cost environmental technology to industry; (2) promoting basic scientific research on the fundamental issues of, among others, combustion, catalysis, and emissions chemistry and physics; and (3) promoting cost-effective, and innovative risk-based environmental regulations based on improved scientific information affecting all areas of the natural gas system.

DOE's goals of improved technologies for environmental quality improvements are outlined in several recent acts and initiatives [e.g., the Energy Policy Act of 1992, the Global Climate Change Action Plan (GCCAP), and The Domestic Natural Gas and Oil Initiative for reducing the environmental impact of energy operations and minimizing the emissions from energy use].
DOE is taking a proactive role in educating State and Federal government decisionmakers on the cumulative impacts that environmental regulations may have on U.S. gas reserves and production, and in encouraging a risk-based approach to environmental regulation.

This parallels the Administration's support of innovative policies to further environmental and energy goals, including reinventing the regulatory system, encouraging costeffective pollution prevention, and fostering the development of new energy efficient technologies. The Administration recognizes the need to move away from the one-sizefits-all approach to regulation and to engage industry in deciding how to most efficiently and flexibly reach environmental goals.

DOE frequently provides comments on regulations proposed by EPA that may affect natural gas supply. DOE staff also serve on State and Federal interagency workgroups. DOE, DOI, and EPA work cooperatively with organizations, such as the Interstate Oil and Gas Compact Commission, to improve State programs that regulate the environmental aspects of gas exploration and production, and to ascertain the effect that State regulatory programs have on natural gas resource recovery.

DOE is working with other Federal agencies to fulfill the commitments made under the United Nations Framework Convention on Climate Change. DOE will help to devise a mitigation strategy that will accomplish the 
Administration's goal to stabilize the greenhouse gas emissions to 1990 levels by 2000 and beyond. Natural gas has a featured role in the strategy because of its environmental advantages over other fossil fuels, and because of the economic benefits of substituting lower priced natural gas for higher priced, greenhouse gas producing alternatives.

EPA has instituted the Green Lights, Golden Carrots, and Energy Star (product labeling) programs in an effort to reduce greenhouse gas emissions. DOE has actively participated in the appliance energy efficiency rating program to contribute to environmental and energy efficiency. Appliance efficiency standards driven by the National Appliance Energy Conservation Act of 1987 have contributed substantially to the introduction of more efficient heating and cooling technologies including many which take advantage of natural gas.

As nations are increasingly concerned about the environment, the international demand for environmental technologies for extraction and production operations and cleaner end-use technologies is growing. DOE will be increasing its assistance to U.S. firms in pursuing this export market, through measures such as helping to identify export opportunities, reducing export barriers, and assisting the Departments of Commerce and State in their promotion programs. stakeholder considerations

Stakeholders play an important role by raising a broad spectrum of issues that are both directly and indirectly impacted by all energy and environmental policy formulation. In developing the Natural Gas Strategic Plan, the Department has interacted with and addressed concerns raised by the following stakeholders:

Congress: The Congress formulates national environmental and energy policy through both its legislative and oversight activities. Congress must work with each of the stakeholders to ensure that energy legislation is both environmentally and economically feasible. Through open communication with all natural gas stakeholders, Congress continues to pursue ways to remove unnecessary statutory barriers to market development.

\section{Federal, State, and Local Regulatory} Agencies: These groups develop regulations out of legislative mandates that will provide for a strong natural gas market while protecting the environment. They include the Federal Energy Regulatory Commission, EPA, and the Public Utility Commissions.

State Governments: State governments implement environmental regulations and policy. They are responsible for permitting or approving siting and operation of exploration, production, and processing facilities, storage sites, pipelines and power plants. They are increasingly concerned with the disposal of 
waste waters and drilling fluids, as well as the protection of environmentally sensitive areas. States that are large natural gas consumers want active government involvement to ensure supply availability and deliverability, while producing States are concerned about resource conservation and management, and proper well abandonment and site remediation.

Natural Gas Industry: These stakeholders seek cost-effective regulations to allow for expanded natural gas exploration, production, and distribution in the nearterm. Their input to environmental policy formation is crucial to understanding the economic impact and feasibility of such policies.

\section{Major Natural Gas Consumers: Major} natural gas consumers include independent power producers, electric utilities, indusiry and commercial buildings. These major users are expected to increase their demand for natural gas in response to existing regulations, like the CAAA, that call for lower emissions and favor the substitution of natural gas for liquid and solid fuels.

Foreign Countries: Joint implementation plans are a major part of the Global Climate Change Action Plan. The Administration sees the cooperation of developing countries and U.S. government and industry as an opportunity to improve global emissions and improve standard of living in developing countries while strengthening the U.S. economy.
Environmental Community: Environmental conservation groups are an important part of environmental and energy policy development. Their efforts to promote emissions reduction and consideration of the environment, have raised awareness of the benefits of natural gas; however, these groups also have concerns about access to wilderness and wetlands for production, and would like to see a more regulated industry to protect the environment.

\section{Research Community: Research} organizations, including the Gas Research Institute, American Gas Association, colleges and universities, and National Laboratories, are an important part of DOE's research, development, and demonstration (RD\&D) efforts. They seek expanded Federal funding for their RD\&D efforts in production, storage, and end-use technologies.

Investment Community: The financial community is concerned with the financial risks of natural gas-related activities, including production and storage facility construction and new technology commercialization. 


\section{key trends}

Public and regulatory bodies continue to press for more stringent environmental regulations in all energy sectors. Restrictions affect not only air, water, and solid waste, but also the siting and permitting of power plants, pipelines, power distribution systems, and exploration and production facilities.

Environmental regulations are becoming more restrictive not only in the levels of pollutants allowed, but also in the number of pollutants regulated. Comprehensive approaches to environmental protection, such as pollution prevention and life-cycle costing, have gained interest among industry and government agencies.

\section{Advanced technologies for achieving} environmental goals at decreasing cost is a major continuing emphasis of both industry and government. Increasing the flexibility in the way industry meets emissions standards is another trend -- trading of emissions allowances is a major step in this direction. There are continuing needs for more costeffective environmental compliance technologies, information that will allow industry and Federal and State governments to manage risk more effectively, and energy impact analyses to provide decisionmakers with better information on the consequences of their actions.

\section{key planning assumptions}

- Natural gas will maintain a competitive advantage for new markets due to its environmental advantages relative to other fossil fuels.

- Natural gas will continue to be part of the longterm solution to global climate change. Atmospheric emissions of greenhouse gases will be discouraged, and ways to collect and utilize unavoidable emissions will be encouraged.

- International environmental issues such as the GCCAP, Montreal Protocol, Rio Treaty, and CFC/HCFC standards will play a larger role in shaping the U.S. environmental debate and will create new opportunities for increased natural gas use.

- Federal, State, and local authorities on environmental issues will expand in depth and scope. Implementation of the CAAA is expected to stimulate natural gas demand in the industrial and electric utility sectors.

- Environmental constraints associated with siting, permitting, and construction of exploration, production, and storage facilities, liquefied natural gas and pipeline projects, and power plants likely will be more stringent.

- CAAA standards and proposed adoption of California air quality standards by other States suggest that low emission vehicle technology, including natural gas vehicles, will be encouraged. Zero-emission vehicles in the worst nonattainment areas will increase electricity demand from clean fuel sources. 


\section{strategic issues}

- Environmental emission regulations will pose one of the constraints on competitive fuel choices over the next 10 to 15 years. For example, application of externality regulations $\left(\mathrm{SO}_{x^{\prime}} \mathrm{NO}_{x^{\prime}}\right.$ and $\left.\mathrm{CO}_{2}\right)$ on utility plants, and mobile and stationary source emission standards for improved air quality will help determine the future competitive advantages and disadvantages.

- Environmental and other social benefits of natural gas utilization currently may not be explicitly recognized in decisionmaking concerning competing energy supplies. Market pricing of competing fuels may not reflect the total fuel-cycle cost of their production, use, and disposal.

- Compliance with Federal and State environmental regulations will be a significant cost in future production and utilization of natural gas.

- Access to Federal lands, including many areas in the Outer Continental Shelf, wilderness areas, and wetlands, is restricted by Federal and State policies. Environmental issues concerning air and water quality and solid waste disposal need to be resolved in an environmentally safe and economically efficient manner to allow natural gas to reach its full potential in the mix of energy sources.

- There is a lack of adequate scientific data upon which to base efficient environmental regulation concerning the impact of energy use on the environment, including natural gas use. Regulations that do not take variations in conditions and environmental risk into account impose unnecessary costs on both industry and govemment.

- Improved environmental modeling and risk analysis methods need to be developed to develop better risk-based regulations. Environmental regulations are often developed with inadequate understanding of the impacts of the operations being regulated and without the proper tools and data to conduct risk analysis.

- Cost/benefit analysis has been inadequately applied in developing many environmental rulemakings, such that important economic and energy efficiency impacts (and their environmental consequences) have not been taken into consideration. 
8-10 


\section{program goals and strategies}

\section{technology}

Goal: Help provide industry with the tools to comply with environmental requirements in order to maintain and increase economical natural gas production. Reduce the cost of compliance with current and future requirements. Provide a sound scientific basis for regulation and mitigation measures.

Strategies:

- Develop lower-cost environmental impact mitigation and waste management technologies and methods for natural gas exploration and production to meet current and future regulatory requirements.

- Sponsor research and environmental science assessment on: global warming; air quality standards (both mobile and stationary sources); geologic hazards; aquifer protection; wetlands operations; and other air, water, and solid waste environmental concerns related to natural gas, including the role of $\mathrm{NO}_{x^{\prime}} \mathrm{CO}_{2^{\prime}}$ methane, and naturally occurring radioactive materials (NORM); and basic research on combustion and catalysis.

- Transfer environmental technologies and technical information to appropriate parties (e.g., gas industry, and Federal and State agencies).

- Seek opportunities to incorporate environmental research into other technology RD\&D efforts by DOE and others.

\section{market}

Goal: Maximize the economical utilization of natural gas in the transportation sector.

\section{Strategy:}

- Develop regulations involving fuel provider fleets and private fleets, as required by EPACT, that accelerate the development of natural gas fuels for transportation. 


\section{policy/regulatory}

Goal: Enhance our capability to analyze the costs and energy impacts of proposed environmental laws and regulations on the gas industry. Better inform Federal and State regulators and the public about the effect of policies on natural gas production, transportation, distribution, and utilization networks.

\section{Strategies:}

- Work with Federal and State regulatory bodies to establish improved criteria for environmental regulations based on such factors as risk assessment, cost benefit analysis, and cumulative regulatory impact.

- Work with regulatory bodies to streamline the process of complying with Federal and State regulations in order to reduce costs and delays, without reducing environmental protection.

- Leverage program resources fully by collaborating with other concerned organizations (e.g., other Federal agencies, trade associations, environmentalists, and universities).

- Promote Federal interagency cooperation and coordination.

\section{environment}

Goal: Allow natural gas to reach its most economically and environmentally efficient position in the available mix of fuels.

\section{Strategies:}

- Contribute to evaluations of environmental science and externalities for all fuel cycles to achieve the optimal total fuel-cycle cost.mix for different energy uses affecting natural gas.

- Develop a knowledge base on impacts and risks associated with exploration and production operations.

- Analyze the energy impact of environmental regulations and legislation, such as new regulations under the CAAA and reauthorization of CWA, and ensure that such information is made available to environmental regulators and legislators.

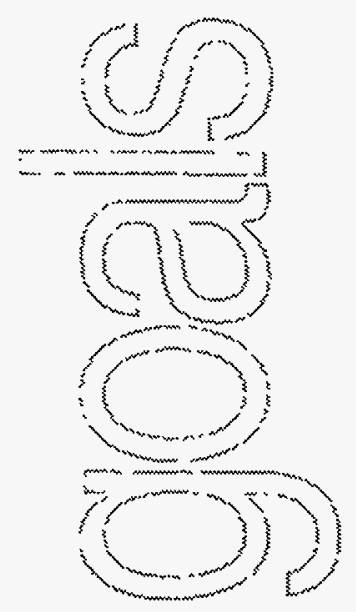


Goal: Provide understanding and information on atmospheric processes controlling ozone and UV-b trends, heterogeneous chemistry and aerosol formation, and the transport, dispersion and ultimate fate of energy-related air emissions, including $\mathrm{NO}_{x}$ and methane.

Strategy:

- Participate in the implementation of the North American Regional Strategy for Tropospheric Ozone (NARSTO), which focuses research efforts on the resolution of the ozone problem in North America. It comprises Cooperative Research and Development Agreement (CRADA) participants from industry, private sector groups, and various Federal and State agencies. Additional collaborators include various international scientific groups. 
8-14 


\section{performance indicators}

- Continue efforts to address regional environmental constraints to natural gas supply. Expansion of analytical capability to assess relationship between environmental compliance and access constraints to natural gas resource recovery. (Near-Term)

- Implementation of risk-based regulations by federal and state agencies. (Near-Term)

- Document estimates of natural gas' contribution to global methane concentrations by 1996 . (Near-Term)

- Provide scientific information and support for the national and international policymaking community concerning global climate change. A primary focus will be impacts from increased levels of greenhouse gases. (Near-Term)

- Reduction of pipeline methane losses by 25 percent, in cooperation with EPA. (Mid-Term)

- Reduction in exploration and production environmental compliance costs by 25 percent. (Mid-Term) 


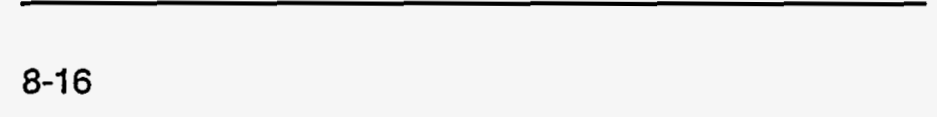




\section{program overview}

\section{program activities summary}

Office of Energy Efficiency and Renewable Energy (Energy Efficiency) invests in RD\&D activities for the utilization of natural gas technologies. Through partnerships with industry, Energy Efficiency develops and deploys innovative gas utilization technologies in the transportation, industrial, utility, and buildings sectors. Program objectives include: analyzing combustion optimization and catalysts, emphasizing emission reductions for natural gas and other alternative fuels; developing industrial technologies to help manufacturers meet current and future environmental regulations and quality objectives; and developing methodologies for gas integrated resource planning and coordinating with the States. The environmental benefits of these utilization technologies are greater efficiency and reduction in harmful air emissions (such as $\mathrm{NO}_{\mathrm{x}}$ and $\mathrm{SO}_{\mathrm{x}}$ ) and other environmental effluents.

Office of Fossil Energy's environmental efforts directed at upstream gas operations include four main activities: (1) analysis to identify key environmental consiraints to natural gas resource recovery; (2) outreach and technology transfer to improve environmental performance and to resolve key environmental constraints; (3) characterization of the health and environmental risks posed by natural gas exploration and production operations; and, (4) development and demonstration of technologies to improve the economics and environmental performance of natural gas exploration and production operations. One area of emphasis is in the treatment and disposal of NORM waste. Program activities include technology demonstration, scientific data compilation, quality assurance, and public education and outreach.

Office of Energy Research conducts fundamental contributing research on the role of methane in global climate change, primarily through two initiatives: (1) development of improved global circulation models as the basis for global climate studies; and (2) studies of background methane emissions from agricultural activities and natural sources such as rice paddies, boreal peat bogs, and ruminant animals. Research includes major efforts at the National Laboratories, and extensive collaboration between National Laboratories and industry and university researchers.

Office of Energy Research's Atmospheric Sciences Program provides research in the chemistry of the lower stratosphere and upper tropospheric regions of the atmosphere. Research efforts are mainly focused toward global climate change issues, and it has contributed to other areas such as air quality through the Committee on Environmental Natural Resources process. 


\section{changes from previous plan}

The Environment program has increased the emphasis on: environmental benefits of natural gas utilization and its contribution to the reduction of greenhouse gas emissions; science-based environmental regulation and risk-based cost-effective pollution control; and performance-based approaches to augment or replace command-and-control measures. For example, reexamining existing regulations to maximize environmental quality while eliminating excessive burdens on industry has led the Administration to refocus on implementation of RCRA on high-risk wastes, to consolidate Federal air quality rules, and to pursue regulatory negotiation and consensus-based rulemaking.

\section{FY 1994-1996 budget summary}

(Dollars in Million)

\begin{tabular}{|l|c|c|c|}
\hline DOE Office & $\begin{array}{c}\text { FY 1994 } \\
\text { Actual }\end{array}$ & $\begin{array}{c}\text { FY 1995 } \\
\text { Approp. }\end{array}$ & $\begin{array}{c}\text { FY 1996 } \\
\text { Request }\end{array}$ \\
\hline Fossil Energy & 2.40 & 3.00 & 5.40 \\
\hline Energy Research & 2.50 & 2.50 & 2.40 \\
\hline Total DOE & 4.90 & 5.50 & 7.80 \\
\hline
\end{tabular}

'Appropriation 


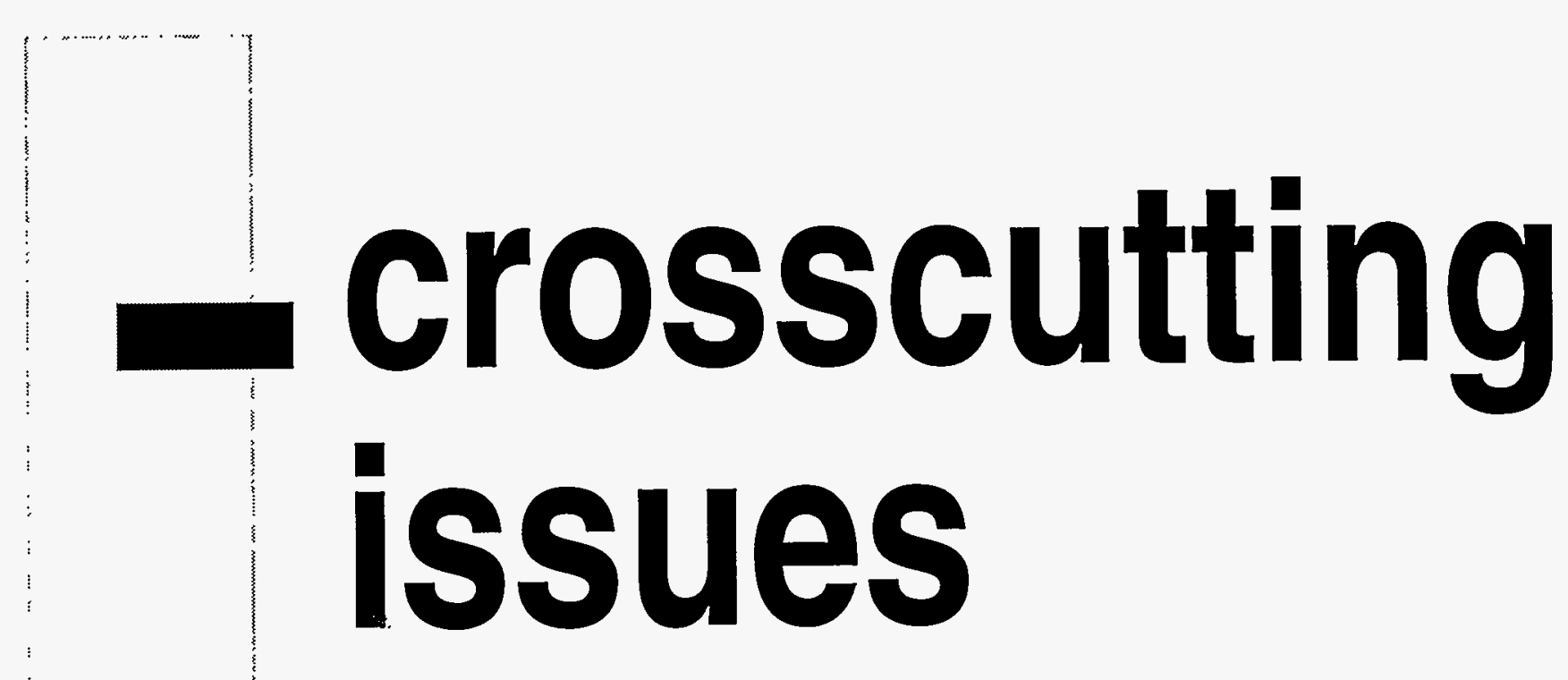




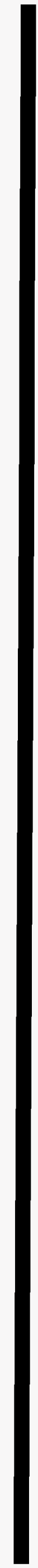

a 
Page No.

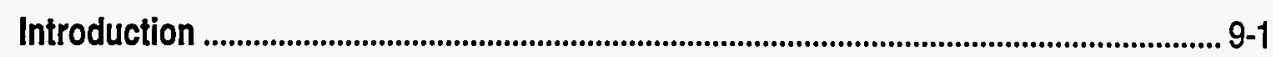

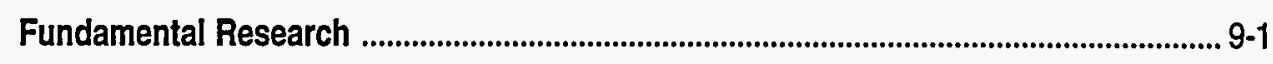

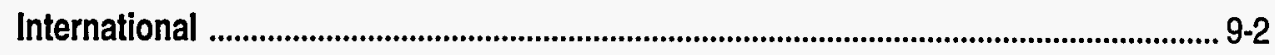

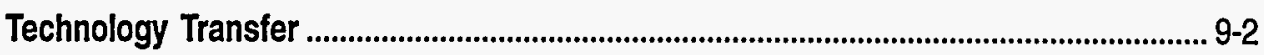

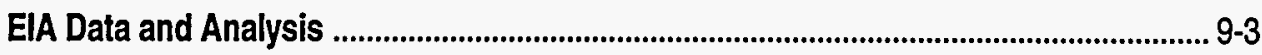




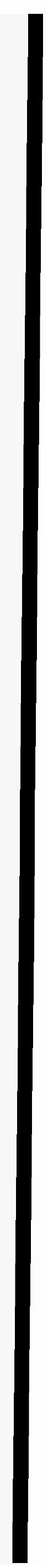




\section{introduction}

There are several issues that crosscut the seven program areas. These issues comprise fundamental research, technology transfer, international, and the Energy Information Administration (EIA) data and analysis in support of the program areas. The following is a brief discussion of these crosscutting issues.

\section{fundamental research}

Basic research is currently being deemphasized in the natural gas industry raising the question of how adequately the technology pipeline is being maintained to provide necessary developments to maintain stable reserves, prices, and markets. As a result, the Federal Government will need to play a large and increasing role in fundamental research activities in all areas of the natural gas system. Basic research in atmospheric and water and solid waste chemistry will also underlie improved environmental technologies and regulatory decisionmaking.

Fundamental research breakthroughs are essential to promote necessary changes in natural gas availability and technology development rather than improvements at the margin. DOE, through its National Laboratory system and broad-based grant programs to university-based researchers, provides essential support to all energy industries. User facilities at the laboratories in particular are regularly used by industry participants for diverse research efforts in materials and combustion, which few, if any, companies can afford. In the future, these user facilities will have an even higher profile with more companies availing themselves of these resources.

Cooperative research and development agreements between the National Laboratories and industrial partners are a major success story and have increasingly provided mutual benefits to both sides. Future partnerships, including university-based researchers, on issues of interest to industry will become a mainstay of basic research, which will feed into the technical service type of applied research still performed by companies.

DOE-funded researchers are leaders in global research issues that cannot be the focus of individual companies, but which form the context of the regulatory environment in which they operate. Such research includes climate change, urban ozone, and environmental waste mitigation standards. 


\section{international}

In support of the natural gas program, DOE undertakes activities and promotes policies to maintain U.S. natural gas technology competitiveness in foreign markets and expand exports of U.S. technologies. Strategic issues involving the international activities include the following: cost of new technologies; political instability in major market areas abroad; highly sophisticated technological competition and financial subsidization from other supplier nations; currency exchange rates, Federal deficit, and other factors impacting trade; lack of knowledge about which international collaborative activities are most effective for improving the international competitiveness of U.S. companies; and potential benefits of research, development, and demonstration efforts to the U.S. in international markets.

DOE's goals for natural gas-related international activities include facilitating the increase of U.S. exports of natural gas exploration, production, processing, and utilization technologies and services; supporting the international competitiveness of U.S. companies exporting natural gas technologies and services; and identifying government actions most effective for improving the international competitiveness of U.S. companies and export of U.S. technologies. DOE's strategies include: (1) working with other Federal government agencies to develop commercial strategic plans for countries with significant market potential, and develop business opportunities through the Trade Promotion Coordinating Committee; (2) continuing Trade Missions to countries with emerging energy markets and potential for export of U.S. technologies; (3) proposing policies and procedures, in coordination with other agencies, for removing, reducing, and/or simplifying laws, regulations, and policies that are found to be barriers to increased technology exports; and (4) identifying technical barriers that affect the export of natural gasrelated technology, e.g., product standards, testing requirements, and use of the metric system; and (5) supporting the establishment of the International Energy Agency's International Centre for Gas Technology Information. The mission of the Centre is to increase the rate of technological innovation for the global gas industry by providing on the Internet, using the World Wide Web server, an international forum for real-time information exchange on natural gas technologies.

\section{technology transfer}

The research and technology development cycle at DOE extends from basic research to technology development and demonstration. Formation of strong, strategic partnerships with industry are promoted through an organized outreach effort to facilitate technology transfer and commercialization. Historically, commercialization or market entry support has been primarily the role of private industry. However, rapid deployment of advanced natural gas technologies provide net national benefits in terms of environmental quality, energy security, and economic 
efficiency that do not accrue directly to the natural gas industry, equipment manufacturerl supplier, or user. In addition, foreign vendors are increasingly subsidized by their governments, impacting the competitive position of U.S. manufacturers. Accordingly, the natural gas industry has encouraged the Department to support market introduction of natural gas technologies that can help achieve national objectives. It is within the Department's charter to support such activities.

The traditional technology development cycle encompasses activities from basic research to technology development, and additional activities that are more deployment related such as systems integration, demonstration, and validation. Additional deployment activities could be supported in partnership with the commercial sector to address market impediments that hinder early acceptance of new natural gas technologies. For example, DOE supports removal and/or reduction of market barriers to the commercialization of advanced natural gas technologies.

The Department also recognizes that over the next 30 years, the international market for energy and environmental technologies will increase. As nations invest in new industrial infrastructure to facilitate growth, there will be a growing emphasis on more efficient, cost-effective, and environmentally cleaner energy production and end-use technologies. The Department's goal is to assist industry in deploying these technologies so that U.S: firms can take advantage of these opportunities. Achieving this goal will require continuing development of strategic partnerships with industry and close coordination and teaming with other Federal agencies.

\section{EIA data and analysis}

A strategic issue confronting the realization of the natural gas program goals is the need for widely available natural gas information to support well-informed natural gas market decisions. These data must be accurate and timely to serve the needs of the increasingly diverse and competitive natural gas industry.

Improved access to Energy Information Administration's energy information includes several electronic dissemination initiatives, such as Internet services, the Energy Information Highway, and the Energy Information Notebook. Comprehensive natural gas data are published in a number of ElA documents, such as the Natural Gas Annual, Natural Gas Monthly, and Monthly Energy Review. Reserves and production data are published in the U.S. Crude Oil, Natural Gas, and Natural Gas Liquids Reserves Report.

A wide range of analytical efforts are published in numerous EIA reports. Some of the major reports follow: Natural Gas 1995: Issues and Trends provides latest data and information including prices, production, transmission, consumption, and financial aspects of the industry. 
The Annual Energy Outlook 1995 presents mid-term forecasts for energy supply, demand, and prices through 2010, while short-term projections appear in the Short-Term Energy Outlook. Other specialized analysis reports include Energy Policy Act Transportation Study: Interim Report on Natural Gas Flows and Rates, which is an analysis of the impact of Federal policies on natural gas transmission flows and rates.

Further improvement of ElA data collection and analysis is expected with the formation and strengthening of strategic partnerships with industry participants, including producers, transmission and distribution companies, and consuming groups.

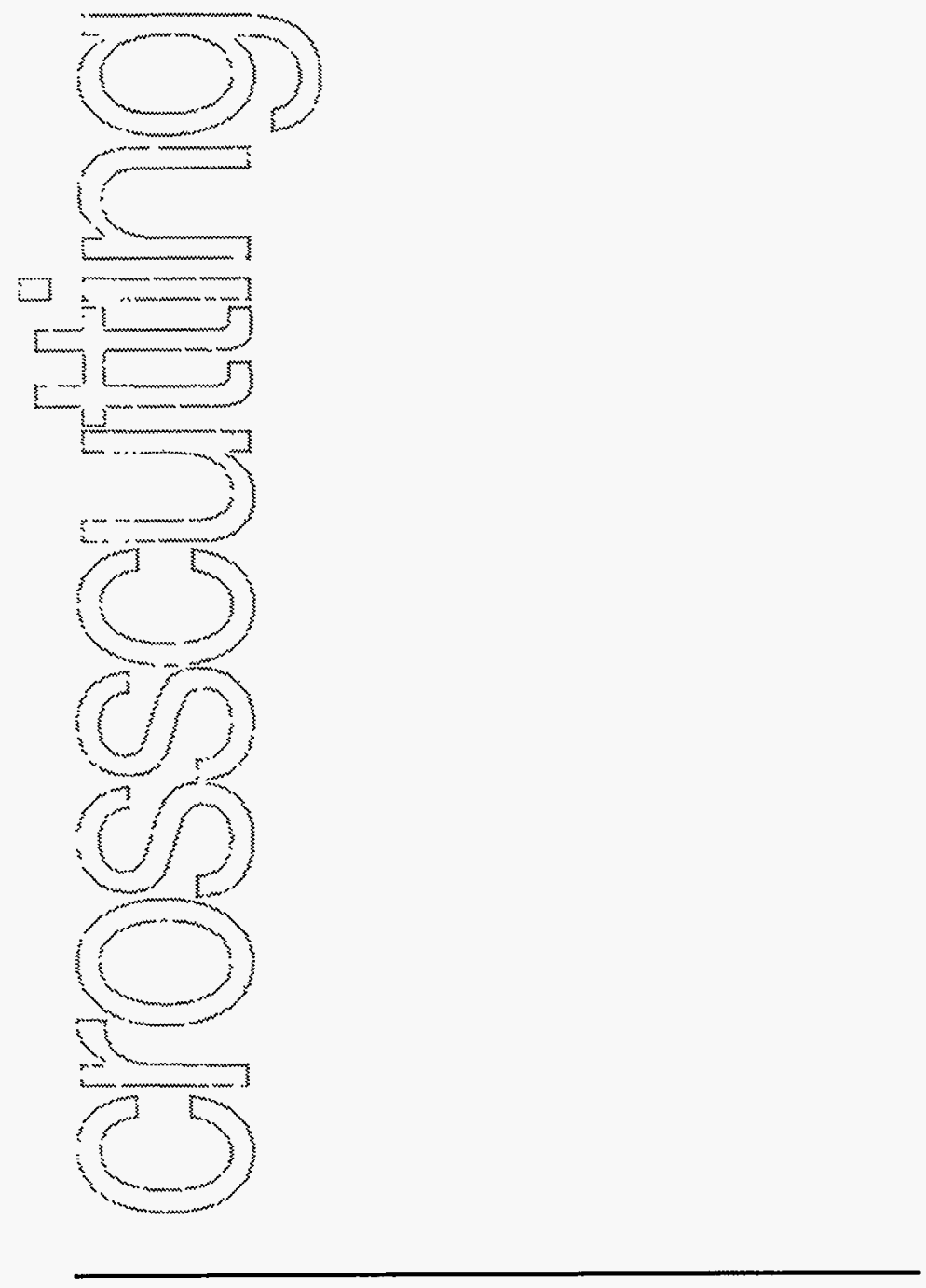

